UNIVERSIDADE DE SÃO PAULO

FACULDADE DE FILOSOFIA, CIÊNCIAS E LETRAS DE RIBEIRÃO PRETO PROGRAMA DE PÓS-GRADUAÇÃO EM EDUCAÇÃO

\title{
O GÊNERO DISCURSIVO FÁBULA EM LIBRAS: UMA ANÁLISE ENUNCIATIVA DE TEXTOS NA ESFERA VIRTUAL
}

HANNA RUSSO CHACON RODRIGUES SILVA

RIBEIRÃO PRETO - SP 


\title{
O GÊNERO DISCURSIVO FÁBULA EM LIBRAS: UMA ANÁLISE ENUNCIATIVA DE TEXTOS NA ESFERA VIRTUAL
}

\author{
VERSÃO CORRIGIDA
}

Dissertação apresentada ao Programa de Pós-Graduação em Educação da Faculdade de Filosofia, Ciências e Letras de Ribeirão Preto da Universidade de São Paulo para obtenção do título de Mestre em Ciências, no Programa Educação.

Área de Concentração: Educação

Orientadora: Prof ${ }^{\mathrm{a}} \mathrm{Dr}^{\mathrm{a}}$ Ana Claudia Balieiro Lodi

Agência Financiadora: FAPESP

RIBEIRÃO PRETO - SP 
Autorizo a reprodução e divulgação total ou parcial deste trabalho, por qualquer meio convencional ou eletrônico, para fins de estudo e pesquisa, desde que citada a fonte.

Silva, Hanna Russo Chacon Rodrigues Silva

O gênero discursivo fábula: uma análise enunciativa de textos na esfera virtual. Ribeirão Preto, 2017. 134 p. : il.

Dissertação de Mestrado, apresentada à Faculdade de Filosofia Ciências e Letra de Ribeirão Preto. Área de concentração: Educação de Surdos.

Orientador: Ana Claudia Balieiro Lodi.

1. Educação Bilíngue para Surdos. 2. Gêneros Discursivos. 3. Língua Brasileira de Sinais. 4. Fábulas 


\section{AGRADECIMENTOS}

A realização desta pesquisa não teria sido possível sem a colaboração dos muitos outros, em especial, daqueles em que nos momentos críticos foram capazes de trazer perspectiva e completude aos meus sentimentos. Sem eles, certamente não seria capaz de enxergar um cenário mais amplo. Assim, inicio meus agradecimentos.

Destaco, primeiramente, à minha companheira de jornada Ana Claudia Balieiro Lodi que em nossa relação me fez compreender o que é ter uma real parceira de trabalho. Por mais que ela insista que estava "apenas” fazendo seu trabalho de orientadora, se não fossem os seus “empurrõezinhos” e os momentos que me proporcionou de "colo” (que ela provavelmente negará), provavelmente eu não seria a Hanna que sou hoje.

Agradeço à Fundação de Amparo à Pesquisa do Estado de São Paulo (FAPESP), pela bolsa concedida.

Às professoras integrantes da banca examinadora que em muito contribuíram para o desenvolvimento dessa dissertação.

Agradeço também à minha família: Rosângela, Bruno, Yannick e Lara. Estes, sem sombra de dúvidas, são meus companheiros de guerra mais antigos e, também, aqueles que sempre me acolheram sem questionamentos. Vocês nem imaginam o quanto contribuíram para essa dissertação.

Ao Fellipe, dificilmente posso transmitir em palavras a gratidão que eu sinto por tê-lo ao meu lado. Nesses dois anos de mestrado, pudemos dar início à nossa vida juntos, foram momentos turbulentos e gratificantes e eu não poderia ter escolhido alguém melhor para me acompanhar.

À Gamera que, literalmente, participou da escrita desse trabalhando sentando em cima do teclado do notebook inúmeras vezes.

Agradeço aos participantes dos grupos de estudos e orientação, sem nossas discussões não haveriam avanços nessa pesquisa: Natália, Ariele, Veridiane, Adriana, Eduardo, Samara e Otávio. E, apesar de não se afirmar enquanto tal, da querida Elomena, que tanto auxiliou nas 
análises dessa pesquisa e que possui uma capacidade inigualável de deixar qualquer atmosfera mais leve.

Por fim, aos meus amigos: Raul, Caio, Nilton, Jp, Jorge, Guilherme, Júlia, Natália, Leandro, Amanda, Ricardo, Cyro, Tobias, Sávio, Daniel, Luís, Alexandre, Fred, Thais e tantos outros que fazem deste círculo de amigos o melhor possível. 


\section{O gênero discursivo fábula em Libras: uma análise enunciativa de textos na esfera virtual}

Resumo: A educação de surdos no Brasil está sendo organizada em meio a conflitos políticos, pois diferentes documentos oficiais se contradizem e constroem sentidos distintos ao conceito de educação bilíngue. Nesse contexto, esta pesquisa se propôs, a partir da teoria enunciativa de Bakhtin, a discutir este modelo educacional e, partindo do que é proposto pelos Parâmetros Curriculares Nacionais para o ensino de português, refletir sobre possibilidades de se construir processos educacionais para surdos em Libras, tendo como base os gêneros do discurso. Desse modo, visou compreender como o gênero fábula tem sido enunciado por surdos em Libras, a partir de textos publicados na esfera virtual, em especial, na plataforma YouTube; foram selecionados 11 vídeos para serem analisados. Observou-se que todos os textos se constituíram enquanto traduções de fábulas já existentes em português, ainda que os autores não tenham se identificado enquanto tradutores. Além disso, as análises mostraram que os vídeos foram produzidos com diferentes propósitos, fato que interferiu, de forma significativa, nas escolhas enunciativas dos sujeitos e na dinâmica interdiscursiva do texto. As fábulas em Libras apresentaram semelhanças temáticas com as existentes em outras línguas, porém revelaram diferenças em suas formas composicionais e escolhas estilísticas. Nos textos mais recentes, observou-se ainda o uso da fábula para reflexões políticas que envolvem as comunidades surdas. Nesse sentido, entende-se que este estudo pode contribuir para a construção de uma educação para surdos que valorize e considere os aspectos discursivos da Libras, para uma reflexão dos diferentes usos da língua a partir dos gêneros discursivos, e para que os alunos conheçam os muitos sentidos que perpassam a história de luta dos surdos, se estes forem postos em relação com os conflitos existentes nas fábulas.

Palavras-chave: Educação Bilíngue para Surdos, Gêneros Discursivos, Língua Brasileira de Sinais. Fábulas. 


\title{
The fable discursive genre in Libras: a enunciative analysis of texts in the virtual sphere
}

\begin{abstract}
Brazillian deaf education is being organized amidst political conflicts, due to different official documents contradicting each other and building distinct meanings to the concept of bilingual education. In this context, this reasearch proposes itself to, based on Bakhtin's enunciation theory, discuss this educational model and, starting from what is proposed by the Parâmetros Curriculares Nacional (National Curricular Parameters) for the teaching of portuguese, reflect upon the possibilities of building educational processes for deaf people in Libras, using discursive genre as a base. Thus, it sought to comprehend how the fable genre was being enunciated by deaf people in Libras, from texts published in the virtual sphere, in special, on the YouTube platform; 11 videos were selected to be analyzed. It was observed that the texts were identified as translations that already existed in Portuguese, even though the authors did not identified themselves as translators. Furthermore, the analysis has shown that the videos were made with different purposes, fact that interfered, in a significant fashion, on the enunciative choices of the subjects and in the interdiscursive dynamics of the text. The fables in Libras show thematic similarities with the ones that exist in other languages, however revealed differences in its compositional forms and stylistic choices. In more recent texts, it was also observed the usage of fables for political reflections that involve the deaf communities. In this sense, it is understood that this study may contribute to the construction of an education for deaf people that values and considers the discursive aspects of Libras, for a reflection on the different uses of the language starting from the discursive genres, and for the students to know the many meanings that pervade the struggles of the deaf community, if those are put in relation to the conflicts that exist in the fables.
\end{abstract}

Keywords: Bilingual Education for Deaf People, Discursive Genres, Brazillian Sign Language, Fables. 


\section{LISTA DE SIGLAS}

AEE - Atendimento Educacional Especializado

$\mathrm{Cl}$ - Classificadores

Conae - Conferência Nacional de Educação

Feneis - Federação Nacional de Educação e Integração dos Surdos

Inep - Instituto Nacional de Estudos e Pesquisas Educacionais Anísio Teixeira

Ines - Instituto Nacional de Educação de Surdos

LA - Língua Alvo

Libras - Língua Brasileira de Sinais

LF - Língua Fonte

MEC - Ministério da Educação

PCNs - Parâmetros Curriculares Nacionais

PNE - Plano Nacional de Educação

Secadi - Secretaria de Educação Continuada, Alfabetização, Diversidade e Inclusão

TILSP - Tradutor e Intérprete de Libras - Língua Portuguesa

USP - Universidade São Paulo 


\section{Sumário}

INTRODUÇÃO

CAPÍTULO I - A EDUCAÇÃO DE SURDOS NO CONTEXTO BRASILEIRO: PRINCIPAIS LEGISLAÇÕES E A

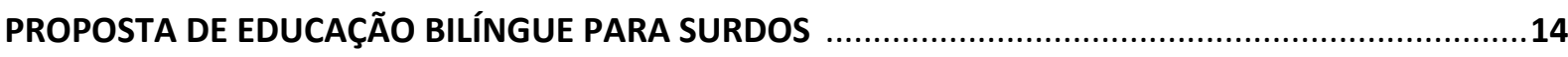

I.1 Compromissos assumidos pela educação brasileira: as Declarações da Unesco ..........................14

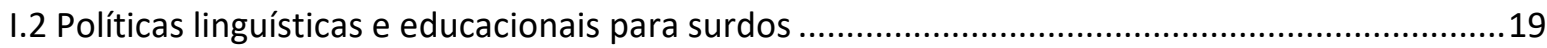

CAPÍTULO II - CONCEPÇÃO DE LÍNGUA E SUAS POSSIBILIDADES PARA A EDUCAÇÃO BILÍNGUE PARA SURDOS

II.1 Palavra como signo ideológico e a formação do discurso interior .33

II.2 Libras como primeira língua e o papel dos outros no processo de constituição do sujeito ........35

II.3 A Libras e os processos educacionais: educação bilíngue para surdos .......................................43

CAPÍTULO III - OS GÊNEROS DO DISCURSO

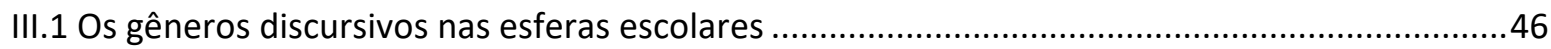

III.2.1 Fábulas: transformações de um gênero na história..............................................................61

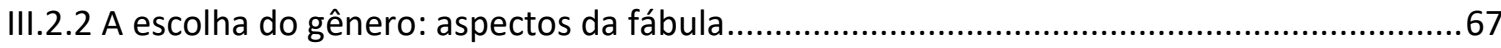

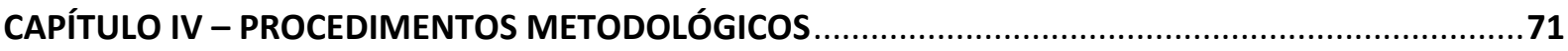

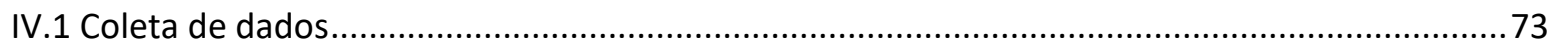

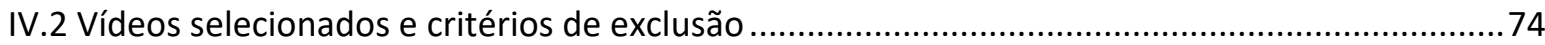

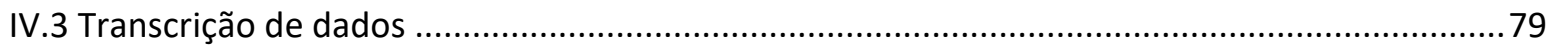

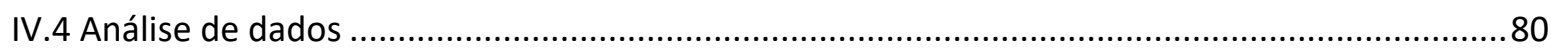

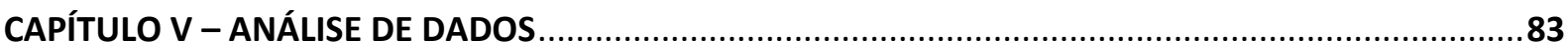

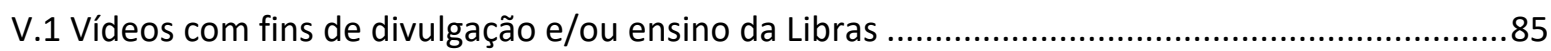

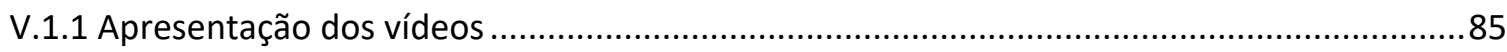

V.1.2 Aspectos enunciativos e discursivos da forma composicional e estilo das fábulas ..............88

V.1.2.1 Algumas considerações sobre a forma composicional e estilo das fábulas ...................99

V.1.3 Aspectos enunciativos, discursivos e semânticos constitutivos do tema das fábulas .......101

V.1.4 Algumas considerações sobre os vídeos de divulgação de língua .......................................106

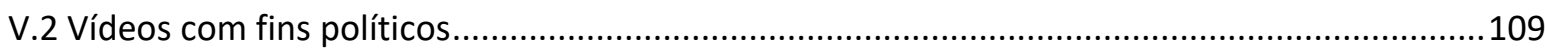


V.2.1 Apresentação dos vídeos.. 109

V.2.2 Aspectos enunciativos e discursivos da forma composicional e estilo das fábulas 110

V.2.2.1 Algumas considerações sobre a forma composicional e estilo das fábulas. 112

V.2.3 Aspectos enunciativos, discursivos e semântico constitutivos do tema das fábulas. 113

V.2.4 Algumas considerações sobre os vídeos com fins políticos 117

CAPÍTULO VI - CONSIDERAÇÕES FINAIS . 120 REFERÊNCIAS BIBLIOGRÁFICAS 125

ANEXOS 129

Anexo A: Ofício de aprovação do Comitê de Ética em Pesquisa. 130

Anexo B: Fábulas em português. 131 


\section{INTRODUÇÃO}

A temática do presente trabalho acompanha minha trajetória profissional desde meus primeiros anos de graduação em Pedagogia. Apesar de, até então, não possuir afinidade ou contato com a educação de surdos, foi no começo de 2013 que tive a oportunidade de iniciar meus estudos e minha pesquisa nessa área, fato que acabou por transformar a forma como eu enxergava muitas das coisas abordadas na universidade.

Em meu segundo ano de graduação, comecei uma Iniciação Científica que mudou os rumos de minha vida. Até então, o mundo acadêmico era cercado de mistérios que pouco me interessavam; seguir uma carreira no campo de educação de surdos nem ao menos era uma cogitação. Ainda assim, fui indicada por uma professora para receber uma bolsa de iniciação científica, sob a orientação da Profa. Dra. Ana Claudia Balieiro Lodi, por ter me saído bem em uma de suas disciplinas. O tema de meu estudo foi relacionado a como têm sido pensada a formação de professores para a educação de surdos, seu título "Formação de professores e educação de surdos: um olhar para os cursos de licenciatura da USP- Campus Ribeirão Preto”.

Com pouca carga teórica na área de educação e nenhum conhecimento na área de educação de surdos, nesse momento minha jornada acadêmica teve início. Sem a menor ideia de como uma pesquisa deveria ser realizada e com muitos medos relacionados à escrita fui, pouco a pouco, descobrindo e me apropriando dos gêneros discursivos que circulam na academia. Meus limites começaram a se expandir e, gradativamente, comecei a aprender formas de estudo que me possibilitassem uma compreensão crítica daquilo que lia. Esse não foi um período fácil. Em meio aos compromissos com a pesquisa e as exigências das disciplinas do curso, precisei me adaptar para realizar os dois com qualidade. Entretanto, foi nesse processo que os conhecimentos apreendidos na universidade começaram a ganhar novas colorações, novos sentidos.

Compreendi que, quando temos um objetivo e conseguimos colocá-lo em relação com os conhecimentos anteriormente adquiridos, acrescido de momentos de orientação, há uma apropriação mais profunda dos conteúdos, uma compreensão que estabelece um diálogo com minha história, com o Curso e com os outros discursos já instaurados em mim.

Durante esse período, participei de meu primeiro grupo de estudos - Educação Bilíngue para Surdos: linguagem e práticas de ensino; neste momento, os objetivos e como eu deveria me portar frente à educação de surdos ainda eram um mistério para mim. Lembro de sempre ouvir as discussões com muita atenção, da mesma forma que me comportava em sala de aula, mas, aos poucos (e com muitos “empurrõezinhos” da orientadora), fui me 
envolvendo e participando do grupo ativamente, até que este acabou por se constituir um de meus espaços favoritos para a discussão de textos e temáticas relacionadas às práticas educacionais com surdos. Percebi, ao tentar explicar o que estudamos do meu "jeitinho", da forma como eu compreendi, que as coisas passavam a fazer sentido e a se organizarem em meu pensamento.

Foi também nesse período que tive minhas primeiras experiências com apresentações envolvendo minha pesquisa: pela primeira vez, não estaria discursando sobre textos e trabalhos alheios (como é comum nas disciplinas de universidade), eu estaria falando sobre o que eu construí, sobre os sentidos e, consequentemente, aquilo que eu pensava a respeito da educação de surdos. A ansiedade era minha única certeza nesses primeiros momentos, porém, aos poucos, fui percebendo que, quanto mais eu dominava e tinha claras as discussões realizadas em meu trabalho, menos medo eu sentia em apresentá-lo publicamente. Apresentar a conclusão da pesquisa de iniciação científica na forma de Monografia, ao término de meu curso, foi uma experiência fantástica: havia ansiedade, mas também havia uma confiança dentro de mim com a qual eu nunca tinha convivido antes.

Todas essas aprendizagens foram me constituindo e me transformando enquanto pesquisadora. Porém, essa iniciação científica, que durou apenas dois anos, levou-me à certeza de que ninguém nasce pesquisador e de que ninguém tem um domínio amplo de um determinado tema com apenas esse tempo. Talvez por causa disso, quanto mais eu estudava, mais sentia que me faltava alguma coisa para que eu pudesse me inserir de verdade nos estudos sobre a educação de surdos. Resolvi prestar o processo seletivo para o Mestrado.

Com o início do mestrado, com a mesma orientadora e também no campo da educação de surdos, os estudos se aprofundaram e precisei fazer escolhas sobre concepções de mundo com bases em diferentes textos e concepções teóricas. Antes mesmo de ingressar no Programa de Pós-Graduação em Educação, fui orientada a iniciar algumas leituras de textos de Bakhtin. Se, na graduação, eu precisava tentar compreender a educação de surdos e, para isso, mergulhei em uma imensa quantidade de textos (cada qual com sua base teórica), na pósgraduação seria o momento de eu consolidar as minhas concepções enquanto pesquisadora.

Bakhtin, em sua vasta quantidade de trabalhos, em momento algum discute especificamente a educação bilíngue de surdos, ainda mais em um contexto tão específico quanto o brasileiro. Entretanto, a filosofia da linguagem do autor e, como muitos de seus estudiosos costumam dizer, a sua forma única de compreender o mundo, permitem a realização de discussões que ultrapassam aqueles vividos pelo autor. A forma como ele 
compreende a língua e, consequentemente, a forma como eu também passei a compreendê-la, permite outro olhar para a educação bilíngue para surdos, outro ângulo sobre o que é se constituir a partir de uma língua minoritária. Outra perspectiva, em especial, sobre as possibilidades de reflexão de uma primeira língua a partir dos gêneros discursivos e, no caso da língua de sinais, as possibilidades de se pensar o uso e desenvolvimento desses gêneros nas esferas escolares.

Com base nessa perspectiva teórica, esse trabalho se propôs a, inicialmente, investigar como diferentes gêneros discursivos, previstos para serem trabalhados nos anos iniciais do ensino fundamental nos documentos oficiais, estariam sendo enunciados por sujeitos surdos nas esferas virtual e escolar. A primeira, por se reconhecer ser esta o espaço em que os surdos, muito em função da materialidade da língua brasileira de sinais - Libras (mas também os ouvintes) compartilham textos dos mais variados gêneros do discurso. A segunda, para compreender com os gêneros previstos, especialmente nos Parâmetros Curriculares Nacionais (PCNs), estariam em circulação nas escolas de surdos e enunciados por professores, principalmente surdos, aos alunos.

Para tanto, foi realizado contato com possíveis escolas a serem visitadas. Iniciamos os trâmites para a inserção da pesquisa na Plataforma Brasil e, posteriormente, com a aprovação do projeto pelo Comitê de Ética em Pesquisa da Faculdade de Filosofia, Ciências e Letras de Ribeirão Preto da Universidade de São Paulo (anexo A), no segundo semestre de 2016, fui visitar três das quatro escolas ${ }^{1}$ que concordaram em participar da pesquisa, localizadas em diferentes estados e regiões do país.

Entretanto, no período em que eu estive nas instituições observando as práticas de ensino e, nas conversas com coordenadores pedagógicos e professores, foi possível perceber que o foco dos processos educacionais ali desenvolvidos, era a enunciação dos gêneros do discurso história infantil e conto de fadas. Além disso, foi possível registrar a presença de apenas um professor surdo, em uma das escolas; os demais docentes eram ouvintes, alguns fluentes em Libras. Meu interesse, no entanto, era ver surdos, usuários da Libras, enunciando diferentes gêneros do discurso com e para os alunos surdos. Dessa forma, o direcionamento dos registros voltou-se para os alunos enunciando gêneros já conhecidos, pois se considerou que estes se constituem enquanto reais falantes da língua brasileira de sinais (Libras). Observei ainda que aqueles gêneros eram trabalhados nas escolas não com o objetivo de

\footnotetext{
${ }^{1}$ Apesar do aceite da quarta escola, esta visita não pode, por diferentes motivos, ser realizada pela pesquisadora.
} 
possibilitar práticas linguísticas em Libras, mas sim como disparadores de práticas de ensino da escrita da língua portuguesa.

Em função de não ser possível atingir o objetivo inicial da pesquisa nos campos investigados e, por sugestão dos membros participantes da banca de qualificação dessa pesquisa, optou-se pela realização desta investigação apenas com textos produzidos por surdos na esfera virtual.

Ao se considerar que todo processo de desenvolvimento e reflexão de linguagem passa, necessariamente, por gêneros do discurso, foi realizado um levantamento dos textos que têm sido produzidos em Libras na esfera virtual por surdos, voltando o olhar, especialmente, a um dos gêneros do discurso esperados para serem objeto de atenção na esfera escolar - fábulas, conforme previsto nos PCNs de língua portuguesa. Considerando ainda os poucos trabalhos envolvendo discussões sobre como se constituem as fábulas em Libras, este estudo buscou responder quatro questões principais:

1. Com quais propósitos estes gêneros foram enunciados?

2. Quais os processos enunciativos constitutivos do gênero em Libras a partir do contexto de produção investigado?

3. Quais as especificidades discursivas encontradas nos aspectos composicionais, estilo e tema das fábulas?

4. Eles diferem da forma como o concebemos em português?

Para a construção deste texto, esta dissertação foi dividida em seis capítulos. No primeiro, foi realizada uma reflexão sobre os documentos internacionais que sustentam a atual política nacional de educação de surdos para, em seguida, realizar uma discussão envolvendo os principais documentos nacionais que dispõem e orientam a educação de surdos no Brasil. No segundo, realizou-se uma discussão e reflexão sobre educação bilíngue para surdos, a partir da teoria discursiva e enunciativa de Bakhtin. Neste, visou-se compreender o que significa assumir a Libras como primeira língua no ambiente escolar e as implicações de sua presença para os processos de constituição dos sujeitos surdos nos anos de escolarização. O terceiro capítulo deste trabalho propôs-se a discutir, a partir da concepção de Bakhtin de gêneros do discurso, como eles se constituem e quais são suas possibilidades no processo de desenvolvimento e reflexão de primeira língua na esfera escolar; posteriormente, buscou-se compreender como o gênero fábula se constituiu ao longo da história. 
O quarto capítulo diz respeito às descrições dos procedimentos metodológicos adotados para esse trabalho. Também foram apresentados e discutidos a seleção e exclusão de textos que compuseram o corpus da pesquisa; assim como o sistema de transcrição adotado.

No quinto capítulo, realizou-se a análise dos vídeos selecionados a partir de duas grandes orientações com base nos objetivos deste trabalho: "Vídeos com fins de divulgação e/ou ensino da Libras” e "Vídeos com fins políticos”. Em seguida, no sexto capítulo, foram realizadas as considerações finais. Por fim, foram apresentadas as referências bibliográficas utilizadas para a construção deste trabalho. 


\section{CAPÍTULO I}

\section{A educação de surdos no contexto brasileiro: principais legislações e a proposta de educação bilíngue para surdos}

\section{I.1 Compromissos assumidos pela educação brasileira: as Declarações da Unesco}

As políticas educacionais no Brasil têm como base conferências mundiais que ocorreram durante a década de 1990. Essas conferências foram realizadas com o intuito de discutir e pensar ações que possibilitassem a transformação dos sistemas de educação de todo o mundo, visto que se reconhecia a importância da educação básica para o progresso social e que tais sistemas possuíam deficiências que acabavam por excluir grande parte da população dos processos escolares (LODI, 2014a).

Tais conferências resultaram no movimento conhecido, atualmente, como de inclusão (social/educacional) e têm, como principais marcos, a Conferência Mundial sobre Educação para Todos (1990), na qual se proclamou a Declaração Mundial sobre Educação para Todos e Marco de Ação para Satisfazer as Necessidades Básicas de Aprendizagem (UNESCO, 1990), e a Conferência Mundial sobre Necessidades Educativas Especiais: acesso e qualidade, na qual se proclamou a Declaração de Salamanca de princípios, política e prática para as necessidades educativas especiais e o Marco de Ação para as Necessidades Educativas Especiais (UNESCO, 1994).

Lodi (2014a), ao realizar uma análise destes documentos, ressaltou alguns princípios que os sustentam. A Declaração Mundial sobre Educação para Todos e Marco de Ação para Satisfazer as Necessidades Básicas de Aprendizagem (UNESCO, 1990), de acordo com a autora, apresenta, como objetivo, a garantia de condições para que todos usufruam de oportunidades educacionais, conferindo aos membros da sociedade uma base de aprendizagem e desenvolvimento humano permanentes sobre a qual os países poderão construir novos níveis e novos tipos de educação. Entretanto, para que tais necessidades educacionais sejam contempladas, é preciso uma "visão ampliada", que supere os recursos e 
estruturas institucionais atuais, bem como os planos de estudo e os sistemas tradicionais de ensino (UNESCO, 1990, Artigo 2).

Esta nova forma de se compreender e se organizar os sistemas educacionais pressupõe a universalização do acesso à escola, sem haver discriminação daqueles que historicamente estiveram à margem da instituição escolar (minorias étnicas, raciais e linguísticas), e a garantia de uma educação que priorize os processos de aprendizagem.

Outro princípio destacado por Lodi (2014a), diz respeito ao reconhecimento da necessidade de criação de programas de alfabetização em línguas maternas nos anos escolares iniciais, visto que esta língua é, de acordo com o documento, um elemento capaz de fortalecer a identidade e a herança cultural. A educação na língua materna é compreendida como uma forma de melhorar ou garantir condições de aprendizagem, podendo esta acontecer em locais que não a rede regular de ensino. Nesse contexto, o documento defende que a criação de programas auxiliares, podem ajudar a satisfazer as necessidades educacionais das crianças, contanto que sejam respeitados os mesmos padrões adotados na escola regular.

Assim, para pensarmos em concretizar os princípios inclusivos, de acordo com Miranda (2008), é necessário pressupor políticas educacionais claras, coerentes e fundamentadas nas diversas relações, nas diferenças linguísticas, culturais e sociais estabelecidas no contexto escolar brasileiro. Lodi (2014b) retoma que essas políticas devem levar em conta, principalmente, a ampliação da educação básica, visto que essa é a condição mais eficaz para fomentar a equidade. No entanto, é ressaltado, no documento, que uma boa educação não pode ser confundida com o oferecimento de uma que apresente menor custo; ela deve atender a um número maior de alunos, aumentando-se assim a capacidade de formação proporcionada pela educação básica.

Falar em políticas e legislações também implica, segundo Laplane (2007), levar em consideração que aquilo que é determinado nos documentos oficiais não acontece de forma isolada dos contextos sociais. Uma legislação procura decretar as concepções que se julgam corretas em um momento e espaço específico, além de procurar atuar com sujeitos de diferentes rendas, acessos a bens materiais e culturais, entre outros fatores. Assim, falar sobre uma política, uma legislação, é falar sobre o momento histórico em que estão inseridos e "à conjuntura política que constitui o substrato para a disseminação dessas ideias, políticas e modos de organização do sistema escolar” (p. 5). Dessa forma, caberia aos países signatários das conferências mundiais a elaboração de políticas, a partir da reflexão dos princípios propostos, com o foco voltado para seus respectivos contextos históricos, sociais e culturais. 
Embora a Declaração de Salamanca (UNESCO, 1994) tenha reafirmado os princípios discutidos no documento anterior, mereceu destaque na análise realizada por Lodi (2014a), a mudança de perspectiva no que diz respeito à concepção de quais alunos poderiam apresentar necessidades educacionais especiais: “crianças deficientes e crianças bem dotadas, crianças que vivem na rua e que trabalham, crianças de populações remotas ou nômades, crianças de minorias linguísticas, étnicas ou culturais e crianças de outros grupo ou zonas desfavorecidas ou marginalizadas”2 (UNESCO, 1994, p. 6. Tradução da autora. Ênfase adicionada). Estas necessidades foram entendidas, ainda, como sendo de natureza permanente ou transitória.

Para se contemplar esta diversidade, Laplane (2007), em seu artigo, discute a necessidade da escola e da sociedade oferecerem serviços adequados para todas as diferenças encontradas, em especial no ambiente escolar, respeitando e atendendo as particularidades de cada aluno, com o intuito de quebrar uma rigidez histórica na qual eles não têm mais que buscar se adaptar ao sistema; cabe aos sistemas se adaptarem para o atendimento de todos os estudantes.

Embora esta Declaração seja reconhecida como um marco significativo para o movimento de educação inclusiva, é possível se observar, na completude do texto, que, ao defender a inclusão, o documento não a restringe ou a limita apenas ao âmbito educacional. Incluir significa também atentar para as questões sociais que, de acordo com Mendes (2006), refere-se à construção de um processo bilateral, no qual sujeitos/comunidades historicamente excluídas e a própria sociedade buscam, conjuntamente, efetivar a equiparação de oportunidades para todos, “construindo uma sociedade democrática na qual todos conquistariam sua cidadania, na qual a diversidade seria respeitada e haveria aceitação e conhecimento político das diferenças” (p. 395). Partindo da perspectiva de que as diferenças humanas constituem a cada um de nós, a nossa singularidade, para que a inclusão social seja alcançada, a educação precisa também partir dessa premissa, criando oportunidades para as particularidades de cada aluno sejam respeitadas, com o objetivo de garantir uma real participação social no futuro.

As Escolas para Todos passam, então, a ser defendidas nesse documento, pois elas seriam, potencialmente, capazes de proporcionar uma educação mais efetiva para a maior parte das crianças, além de apresentarem um custo-benefício maior para todo o sistema educacional, visto que as escolas especiais possuem um alto custo de manutenção e são

\footnotetext{
${ }^{2}$ No original: "Deben acoger a niños discapacitados y niños bien dotados a niños que viven en la calle y que trabajan niños de poblaciones remotas o nómadas, niños de minorías lingüísticas étnicas o culturales y niños de otros grupos o zonas desfavorecidos o marginados.” (UNESCO, 1994, p. 6. Ênfase adicionada.)
} 
capazes de atender apenas a uma pequena quantidade de alunos. Entretanto, não há, no todo do texto da Declaração de Salamanca, contrariando a interpretação realizada pelos responsáveis pela educação no Brasil, a defesa para que as escolas especiais deixem de existir, na medida em que se reconhece serem elas importantes para a garantia da educação e, portanto, para a participação social de crianças, cujas especificidades, a escola não é capaz de atender.

Neste contexto, orienta-se que, no caso da educação de surdos, esse princípio seja seguido. Para isso, políticas públicas precisam ser pensadas a fim de se garantir:

21. (...) as diferenças individuais e as distintas situações. Deve-se levar em conta a importância da língua de signos como meio de comunicação para todos os surdos, por exemplo, e deverá ser garantido que todos os surdos tenham acesso ao ensino na língua de signos de seu país. Pelas necessidades específicas de comunicação dos surdos e dos surdos/cegos, seria mais conveniente que lhes seja concedida uma educação em escolas especiais ou em classes e unidades especiais nas escolas regulares (UNESCO, 1994, p.18. Tradução da autora. Ênfase adicionada) ${ }^{3}$

Observa-se assim que, embora o documento defenda, ao longo de vários itens, os princípios da Escola para Todos como forma de se garantir uma educação em equidade à totalidade de alunos, nele também se reconhece que, para ser respeitada a particularidade linguística dos alunos surdos e surdo-cegos, espaços educacionais outros devem ser organizados de maneira que lhes seja assegurada a presença da língua de sinais em seus processos educacionais; esses alunos, portanto, são compreendidos no documento, não mais a partir dos sentidos que lhes faltam, mas como grupos socioculturais e linguísticos minoritários.

A proposição de escolas ou classes no interior das escolas regulares especialmente pensadas aos alunos surdos pode gerar certa tensão, visto que o movimento de inclusão se contrapõe, justamente, às perspectivas educacionais que trabalham a partir da separação dos alunos, considerados deficientes, das salas regulares, transferindo-os para salas ou escolas especiais. Entende-se, no entanto, não ser este o caso. Não se trata, aqui, de uma separação

\footnotetext{
${ }^{3}$ No original: "21. (...) las diferencias individuales y las distintas situaciones. Debe tenerse en cuenta la importancia de la lengua de signos como media de comunicación para los sordos, por ejemplo, y se deberá garantizar que todos los sordos tengan acceso a la enseñanza en la lengua de signos de su país. Por las necesidades específicas de comunicación de los sordos y los sordos/ciegos, sería más conveniente que se les impartiera una educación en escuelas especiales o en clases y unidades especiales dentro de las escuelas ordinarias" (UNESCO, 1994, p.18. Ênfase adicionada.)
} 
por conta de uma “deficiência”, mas sim por levar em consideração a diferença linguística deste grupo sociocultural; diferença esta que, se não for devidamente respeitada, pode gerar ainda mais desigualdades quando pensamos no âmbito da inclusão social. Isso porque a não garantia da língua resulta em dificuldades seríssimas de escolarização, fato que acaba por não permitir que alunos surdos tenham os mesmos direitos à educação que os ouvintes e, portanto, que não tenham possibilidades de participar em equidade nas esferas sociais.

Lodi (2014a) expõe ainda que os documentos citados, ao valorizarem a possibilidade de escolha de pais e alunos quanto ao modelo educacional que lhes forem mais adequados, não restringem a escolarização de todos os alunos a apenas um tipo de escola, aspecto pouco discutido nas políticas educacionais de nosso país. Percebe-se, portanto, que o documento reconhece, explicitamente, que a escola destinada a ouvintes é incapaz de garantir a educação de surdos e, apesar de não usar como termo específico “educação bilíngue para surdos”, a proposição realizada indica ser este o caminho.

Para finalizar esta discussão, ressaltam-se ainda os apontamentos realizados por Lodi (2014a) quanto aos compromissos assumidos pelos países signatários das referidas Declarações. Como tais propostas educacionais implicam em investimentos de recursos internacionais, espera-se, de todos os envolvidos, a garantia dos princípios nelas presentes, assim como a apresentação de resultados que comprovem melhoria no acesso e na permanência dos alunos nos sistemas educacionais. Nesse sentido, a autora reconhece não ser possível negar que há também pressões de ordem política e econômica que têm influenciado a organização educacional proposta no Brasil, cuja preocupação tem se materializado mais no aspecto quantitativo (número de matriculados no sistema regular de ensino x números de alunos matriculados em escolas específicas) do que qualitativo, como forma de mostrar um retrato mais real do cenário educacional brasileiro. Esta constatação pode ser observada nos vários Resumos Técnicos do Censo Escolar da Educação Básica, apresentados pelo Ministério da Educação/Instituto Nacional de Estudos e Pesquisas Educacionais Anísio Teixeira (MEC/Inep).

No entanto, simultaneamente a essas conferências, durante o período de 1980 até 1999, intensificaram-se os movimentos mundiais que defendiam a língua de sinais como constitutiva dos surdos e que promoviam a ideia de se implantar um modelo educacional que se organizasse a partir desta língua. Tendo a educação bilíngue como modelo educacional para surdos, acreditava-se ser possível romper com a ideia histórica de ser, este campo da educação, uma ramificação da educação especial. E, apesar de termos lutas históricas 
importantíssimas por parte das comunidades surdas, como pode ser observado na seção seguinte, não é essa a realidade atual do Brasil.

\section{I.2 Políticas linguísticas e educacionais para surdos}

Buscar-se-á, para esta discussão, analisar os principais documentos que regem a educação de surdos no Brasil. A fim de se concretizar esta análise, serão discutidos quatro importantes documentos, apresentados, neste texto, segundo a ordem cronológica em que foram publicados: o Decreto Federal n 5.626, de 2005; a Política Nacional de Educação Especial na Perspectiva da Educação Inclusiva, de 2008; o Plano Nacional de Educação (PNE), de 2014; e a Lei $n^{\circ} 13.146$ - Lei Brasileira da Inclusão de 2015. A escolha destes documentos deve-se ao reconhecimento de que há, em todos eles, aspectos que determinam como a educação de surdos deve ou deverá ser organizada no país.

O Decreto $n^{\circ}$ 5.626/05, conforme discutiu Lodi (2013), retrata a mobilização das comunidades surdas em defesa de seus direitos linguísticos também nos espaços educacionais, além de uma compreensão das pessoas surdas pelo viés da diferença linguística. Nesse sentido, é possível perceber, neste Decreto, o respeito à Libras e à cultura dos surdos, quando nele é definido que a educação para estes alunos, na Educação Infantil e nos anos iniciais do Ensino Fundamental, deva ser realizada a partir dos princípios da educação bilíngue e, portanto, desenvolvida em escolas para surdos. Quando isso não for possível, em salas de surdos no interior de escolas regulares. Esses espaços educacionais são entendidos como uma escola/classe em que a Libras está presente em período integral, logo, que respeite os aspectos culturais próprios das comunidades surdas, que diferem daqueles dos ouvintes presente nas escolas regulares (KLEIN; FORMOZO, 2008). Por este motivo, o Decreto define a necessidade da formação de professores bilíngues Libras - português para os níveis iniciais de escolarização, além de dar particular ênfase à necessidade de haver professores surdos nas unidades escolares de atendimento aos surdos.

Para os anos finais do Ensino Fundamental e Ensino Médio, são responsáveis pela educação, docentes licenciados nas diferentes áreas do conhecimento, que serão acompanhados por tradutores e intérpretes de Libras - língua portuguesa (TILSP). Estes docentes, no entanto, devem compreender a singularidade linguística dos surdos (BRASIL, 2005, Artigo 22, Inciso II); construir mecanismos alternativos de avaliação dos conhecimentos que considerem a Libras (BRASIL, 2005, Artigo 14, Inciso VII) e desenvolver recursos didáticos que busquem apoiar a educação de alunos surdos (BRASIL, 2005, Artigo 
14, Inciso VII). O documento busca também garantir que a Libras não esteja restrita às salas de aula e, nesse sentido, defende sua difusão entre professores, alunos, funcionários, direção da escola e familiares (BRASIL, 2005, Artigo 14, Inciso V).

No documento é possível perceber uma perspectiva de sujeito surdo não mais como ele foi visto, historicamente, por ouvintes - como aquele que é incapaz de ouvir, mas sim como aquele que se constitui por uma língua diferente. O Decreto, portanto, deixa de lado a perspectiva da deficiência, da incapacidade e passa a conceber o surdo como "falante" de outra língua. Percebe-se assim, no Decreto, que a proposta educacional distancia-se da maneira como a educação especial compreendia a educação de surdos em um passado não muito longínquo; constitui-se, portanto, a partir de uma perspectiva que considera a diferença sociocultural e linguística existente entre surdos e ouvintes.

Desse modo, partindo do pressuposto do respeito às diferenças, previsto na Declaração de Salamanca (UNESCO, 1994), e por meio de espaços educacionais diferenciados, o Decreto visa a garantir o direito dos surdos a uma educação em língua de sinais. Nesse sentido, tornase possível afirmar que o Decreto não se contrapõe aos princípios da inclusão social, mas entende que, para alcançá-la, a educação deste grupo sociocultural deve contemplar e respeitar suas características linguísticas.

O mesmo, no entanto, não pode ser dito da Política Nacional de Educação Especial na Perspectiva da Educação Inclusiva, que, embora também proponha a educação bilíngue para surdos e cite, para tal defesa, o Decreto ${ }^{\circ}$ 5.626/05 e a Lei $n^{\circ}$ 10.436/02 (Lei que reconhece a Libras como meio legal de comunicação das comunidades surdas), fá-lo a partir de uma concepção diferente daquela presente no Decreto (LODI, 2013). Esta afirmação pode ser subsidiada a partir da seguinte colocação:

Para o ingresso dos estudantes surdos nas escolas comuns, a educação bilíngüe - Língua Portuguesa/Libras desenvolve o ensino escolar na Língua Portuguesa e na língua de sinais, o ensino da Língua Portuguesa como segunda língua na modalidade escrita para estudantes surdos, os serviços de tradutor/intérprete de Libras e Língua Portuguesa e o ensino da Libras para os demais estudantes da escola. $\mathrm{O}$ atendimento educacional especializado para esses estudantes é ofertado tanto na modalidade oral e escrita quanto na língua de sinais. Devido à diferença lingüística, orienta-se que o aluno surdo esteja com outros surdos em turmas comuns na escola regular (BRASIL, 2008).

Lodi (2013) destaca que o documento, ao prever a educação bilíngue como "o ensino escolar na Língua Portuguesa e na língua de sinais”, acaba por não especificar qual língua 
deverá ser utilizada pelo professor nas salas regulares, desconsiderando que o uso de ambas as línguas, simultaneamente, é impossível. Fica, portanto, subentendido que caberá aos TILSP o uso da língua de sinais, na medida em que a atuação desse profissional é prevista em todos os níveis de ensino. Entende-se assim, em consonância com a autora, que a eles é atribuída a responsabilidade pelo ensino dos estudantes surdos, visto que professores e alunos não compartilham uma mesma língua.

Segundo Lodi (2013), a Política desconsidera ainda a importância do processo de apropriação da Libras pelos alunos, condição primeira para qualquer processo de escolarização, pois, ao prever a presença dos TILSP em todos os níveis educacionais, esse documento assume que as crianças surdas chegam às escolas com o completo domínio da língua. Não considera, portanto, que a maior parte dos alunos possui pais ouvintes e que, por este motivo, não irão compartilhar de uma mesma língua no interior da família; desse modo, a escola torna-se o lugar privilegiado para se garantir a interação verbal em Libras pelos alunos o mais cedo possível. Esta não garantia (fato ignorado pela Política), pode resultar em um desenvolvimento de linguagem tardio, realizado por ouvintes em sala de aula e/ou no atendimento educacional especializado, espaços estes que deveriam ser destinados aos processos educacionais dos surdos. Por fim, a Política ressalta a necessidade de alunos surdos estarem juntos em uma mesma turma, por conta da diferença linguística, mas ao não compreender a importância da presença dessa língua em tempo integral na educação desses sujeitos, a justificativa em prol da diferença se torna vazia.

Além disso, ao pressupor a inclusão como o convívio entre surdos e ouvintes, a Política desconsidera as especificidades de cada língua além das tensões existentes na relação entre línguas. A língua de sinais, no caso do Brasil, a Libras, é uma língua viva, o que significa que constantemente é transformada pelo uso, por seus usuários, que ao mesmo tempo por ela são transformados. Diferente das línguas orais, as línguas de sinais possuem uma materialidade não baseada no som, mas sim visual, espacial e gestual, "que se organiza no espaço de enunciação - semicírculo virtual localizado à frente do enunciador, onde são realizados os processos enunciativos” (LODI, 2014b, p.100).

A Libras se constitui uma língua ágrafa, o que não denota inferioridade e/ou desvalorização ou mesmo impossibilidade de registro da mesma, pois conforme Peluso (2007; 2011) e Lodi (2014b), textos/discursos produzidos e elaborados em língua de sinais, se registrados por meio de videogravações, podem constituir-se instrumentos para a perpetuação e compartilhamento de textos entre surdos (nos espaços escolares, acadêmicos, virtuais, entre 
outros). Reconhece-se, portanto, que por meio das videogravações respeita-se a lógica particular da língua e os aspectos culturais que lhe são intrinsecamente relacionados.

Considera-se assim que por meio das videogravações, pode se contribuir para os processos de transformação social e cultural, à medida que elas se constituem uma ferramenta de renovação de experiências, de convívio e conflito com diferentes pontos de vista sobre a realidade e no estabelecimento de novos processos de relações sociais (e, consequentemente, ideológicas) (LODI, 2014b, p. 108).

Acrescenta-se, ainda, que a Política desconsidera a relação histórica entre a Libras e a língua portuguesa, marcada pelas décadas de opressão linguística. Nesse período a língua de sinais e os surdos foram oprimidos em nome da normalização - a qual se reconhecia o português enquanto língua superior, necessária para o desenvolvimento e “ouvintização” dos alunos surdos. Pressupor que essas línguas conviverão harmonicamente é ignorar a história de lutas e a subjetividade dos sujeitos surdos, visto que, a todo momento seus valores de mundo estarão em conflito com os de ouvintes (sejam eles professores ou outras crianças) em uma relação desigual, visto que os valores ouvintes já se encontram reconhecidos e valorizados.

Tais situações podem ser exemplificadas com a proposta da Política de inclusão de surdos nas salas com ouvintes, onde a Libras será utilizada, unicamente, pelo aluno surdo e seu intérprete, fato que vem reafirmar a desigual relação de valores, historicamente construída, entre essas duas línguas. Nesse contexto, há o predomínio das formas de significação do mundo específicas e permitidas pela língua portuguesa. Esta restrição do uso da língua de sinais apenas a alunos surdos e TILSP, deixa explicito, ainda, a pouca aceitação/reconhecimento desta língua pelas instituições escolares.

Dessa forma, apesar de utilizar uma nomenclatura que prevê o respeito linguístico dos alunos surdos (“educação bilíngue”), torna-se possível afirmar que a Política, ao restringir as opções de escolarização à um único modelo, rompe, não apenas com o disposto no Decreto $\mathrm{n}^{\circ}$ 5.626/05 como também com os documentos internacionais discutidos na seção anterior.

Fazem-se, então, perceptíveis as distintas concepções presentes no Decreto e na Política, respectivamente, no que se refere à ser surdo: sujeito que se constituí a partir de outra língua (Libras, já que é reconhecido seu status linguístico) e como sujeito que se caracteriza pelo sentido que lhe falta. Neste último contexto, ser surdo permanece, como ocorreu historicamente, um sinônimo de deficiência, de incapacidade de tornar-se ouvinte. O mesmo pode ser dito ao se comparar o sentido atribuído à educação bilíngue para surdos em ambos os 
documentos: modelo educacional que reconhece a importância da língua de sinais no desenvolvimento e constituição dos alunos surdos e que, portanto, deve ser realizada em um local diferenciado, que respeite essa língua; e como parte da educação inclusiva, que prevê que todos devam conviver em um ambiente inclusivo, sem a diferenciação ou reconhecimento da Libras, que distanciada de seu status linguístico, é tida como um instrumento para a aprendizagem do português ou como um recurso didático para o acesso dos alunos aos conteúdos escolares (PELUSO; LODI, 2015).

O Decreto e a Política, embora contendo contradições importantes para o delineamento de políticas linguístico-educacionais para surdos, serviram de base para outros documentos elaborados posteriormente, que acabaram por expor as mesmas tensões existentes entre o Decreto e a Política no que diz respeito à concepção de educação bilíngue e de "ser surdo”. Estes são: o Plano Nacional de Educação (PNE), de 2014, e a Lei Brasileira de Inclusão, de 2015.

O PNE é

uma lei ordinária com vigência de dez anos a partir de 26/06/2014, prevista no artigo 214 da Constituição Federal. Ele estabelece diretrizes, metas e estratégias de concretização no campo da Educação. Municípios e unidades da federação devem ter seus planos de Educação aprovados em consonância com o PNE (BRASIL, 2014).

Dentre as vinte metas estabelecidas nesse documento, a Meta 4, denominada, Educação Especial/Educação Inclusiva merece destaque frente aos objetivos deste texto. Conforme discutido por Silva e Lodi (2016), é possível observar, na contextualização da Meta 4, um discurso tecido a partir dos dados presentes na Política Nacional de Educação Especial, na qual se afirma que, como resultado da implementação da política inclusiva, houve um grande aumento na matrícula de alunos da educação especial nas escolas regulares, entre eles as de crianças surdas. Entretanto, concordamos com Lodi (2014a) ao afirmar que os dados referentes ao aumento de matrículas na rede regular são apresentados sem a devida problematização, visto que não consideram as condições concretas que levaram a esses resultados. Um dos motivos foi o fechamento das escolas especiais, fato que determinou, por falta de alternativas, que os alunos se matriculassem na rede regular de ensino. Esses dados, que buscam expor a melhoria no acesso à educação básica, são, entretanto, incapazes de afirmar uma melhoria na qualidade de ensino ou da permanência desses alunos.

Ainda referente à Meta 4, em sua descrição, observa-se que esta tem como objetivo, 
universalizar, para a população de 4 (quatro) a 17 (dezessete) anos com deficiência, transtornos globais do desenvolvimento e altas habilidades ou superdotação, o acesso à educação básica e ao atendimento educacional especializado, preferencialmente na rede regular de ensino, com a garantia de sistema educacional inclusivo, de salas de recursos multifuncionais, classes, escolas ou serviços especializados, públicos ou conveniados (BRASIL, 2014)

Cabe destacar que apesar do PNE utilizar, em diferentes momentos, o previsto no Decreto n 5.626/05, estabelece também um diálogo com a Política de Educação Especial no que diz respeito à concepção de surdos, na medida em que não se observa, neste documento, referência a este grupo social como usuários de uma língua distinta, que caracteriza a diferença constitutiva das pessoas surdas. A educação de surdos neste documento, toma como referência o previsto pela Política de Educação Especial e, portanto, concebe estes alunos a partir da "deficiência”, da incapacidade de ouvir. Essa concepção contraria os movimentos surdos em defesa de seus direitos, distanciando-se, assim, do conceito político e ideológico do que significa ser surdo - grupo que, por utilizar uma língua diferente, insere-se também em uma cultura diferente. Ser surdo não é, portanto, ser incapaz de ouvir, mas sim ser capaz de significar o mundo a partir de uma língua, logo cultura diferentes.

Ao se analisar as estratégias 4.7 e 4.13 da Meta 4, que tratam, especificamente, da educação de surdos, foi possível encontrar nelas também algumas contradições. Na primeira, denominada "Braille e Educação bilíngue Libras/língua portuguesa”, busca-se:

Garantir a oferta de Educação bilíngue, em Língua Brasileira de Sinais (Libras) como primeira língua e na modalidade escrita da língua portuguesa como segunda língua, aos alunos surdos e deficientes auditivos de 0 a 17 anos, em escolas e classes bilíngues inclusivas, nos termos do art. 22 do Decreto $\mathrm{n}^{\circ}$ 5.626, de 22 de dezembro de 2005, e dos arts. 24 e 30 da Convenção Sobre os Direitos das Pessoas com Deficiência, bem como a adoção do Sistema Braille de leitura para cegos e surdos-cegos (BRASIL, 2014. Ênfase adicionada).

Observa-se, na redação desta estratégia, conforme discutiram Silva e Lodi (2016), que embora a referência para se garantir a educação bilíngue seja o Decreto n 5.626/05, o modelo educacional proposto diz respeito à “escolas e classes bilíngues inclusivas”. Educação bilíngue não significa a presença de duas línguas no interior das salas de aula, materializadas por intermédio de interlocutores diferentes: professor (língua portuguesa) e TILSP (Libras). Assumir esse modelo de educação significa pensar em espaços específicos (escolas e/ou 
classes) em que a Libras é enunciada por todos no interior da escola/sala de aula. O termo “educação bilíngue inclusiva”, que aparece pela primeira vez em um documento oficial, representa assim, por si, as contradições presentes no Decreto e na Política. Ou seja, educação bilíngue entendida como uma modalidade de ensino que respeita as particularidades linguísticas dos surdos em oposição ao movimento de educação inclusiva, que acredita que educação bilíngue significa o uso de duas línguas no interior da sala de aula. Novamente, assim como presente na contextualização da Meta, observa-se a forte influência do texto da Política e, portanto, a mesma concepção de educação bilíngue prevista por este documento, muito embora o Decreto seja trazido como referência para se pensar esta estratégia.

No entanto, nessa mesma estratégia, foram trazidos ainda para dialogar com o Artigo 22 do Decreto, os Artigos 24 e 30 da Convenção sobre os Direitos das Pessoas com Deficiência (BRASIL, 2009a). No primeiro, afirma-se que caberá aos Estados assegurar “o sistema educacional inclusivo em todos os níveis” (BRASIL, 2009a, Artigo 24, Inciso 1); entretanto, ao tratar especificamente dos surdos, encontram-se as seguintes disposições:

b) Facilitação do aprendizado da língua de sinais e promoção da identidade linguística da comunidade surda;

c) Garantia de que a educação de pessoas, em particular crianças cegas, surdocegas e surdas, seja ministrada nas línguas e nos modos e meios de comunicação mais adequados aos indivíduos e em ambientes que favoreçam ao máximo seu desenvolvimento acadêmico e social (BRASIL, 2009a, Art. 24, Inciso 3. Ênfase adicionada).

No que diz respeito ao Inciso 4, do Artigo 30, do Decreto $n^{\circ}$ 6.949/09, nele é disposto que "as pessoas com deficiência farão jus, em igualdade de oportunidades com as demais pessoas, a que sua identidade cultural e linguística específica seja reconhecida e apoiada, incluindo as línguas de sinais e a cultura surda" (Ênfase adicionada).

Inicialmente, destaca-se a questão da “facilitação do aprendizado da língua de sinais” junto a caracterização de que essa educação deva ser ministrada nas "línguas e nos modos e meios de comunicação mais adequados”; tais afirmações remetem à uma não clareza do papel da Libras no interior de uma educação para surdos.

A Libras pensada para ser ensinada, aponta para a desconsideração do período de assimilação e desenvolvimento de linguagem dos alunos surdos e para o fato de que ninguém aprende uma primeira língua (assimila-se uma língua vivendo, interagindo com interlocutores usuários desta língua). Do mesmo modo, ao definir que a educação deva ser ministrada na 
língua e nos modos e meios de comunicação mais adequados, leva a compreensão de que a língua de sinais é concebida como instrumento de comunicação; ou seja, um instrumento de acesso à língua portuguesa e um recurso para a aprendizagem dos conteúdos do currículo escolar.

Observa-se assim, em consonância com o discutido por Silva e Lodi (2016), conflitos conceituais, no interior desta estratégia, semelhantes aos existentes entre o Decreto $\mathrm{n}^{\circ}$ 5.626/05 e a Política de Educação Especial, pois ao mesmo tempo em que se defende a educação “bilíngue inclusiva” em diálogo explícito com a Política, ao citar os Artigos 24 e 30 do Decreto $n^{0}$ 6.949/09, promete-se a garantia de espaços educacionais que possibilitem o desenvolvimento de uma identidade linguística diferenciada (possível apenas se houver um grupo de pares surdos convivendo no interior do espaço escolar) e reconhecem-se os aspectos culturais específicos deste grupo social e linguístico minoritário (assim como no Decreto $\mathrm{n}^{\circ}$ 5.626/05). Entretanto, ao se remeter à educação “bilíngue inclusiva”, espera-se que a educação de tais sujeitos seja realizada em locais que restringem a convivência com usuários fluentes desta língua, seguindo-se, portanto, os pressupostos na Política.

No que se refere à estratégia 4.13, que se destina à ampliação de profissionais da educação, são previstos no que diz respeito aos surdos, TILSP, professores de Libras, prioritariamente surdos, e professores bilíngues. Observa-se aqui a possibilidade de um maior diálogo com o disposto no Decreto $n^{\circ}$ 5.626/05; no entanto, ao considerar o disposto na estratégia 4.7, particularmente no que diz respeito à educação bilíngue inclusiva nela proposta, deve-se questionar as funções a serem desenvolvidas por cada um destes profissionais no espaço escola.

Observa-se, desse modo, a fragilidade presente em nossas legislações no que diz respeito à educação de alunos surdos, cuja ênfase no modelo bilíngue, tal como defendido pelas comunidades surdas e pesquisadores que apoiam este modelo educacional, se dá, apenas, nos documentos internacionais, como é o caso do Decreto $n^{\circ}$ 6.949/09. Quando na defesa de uma proposta bilíngue a este grupo, conforme materializada no PNE, o uso da Libras nos espaços escolares cede lugar ao discurso da educação inclusiva, como proposto pela Política de Educação Especial, inviabilizando a igualdade de oportunidades educacionais aos alunos surdos (SILVA e LODI, 2016).

Outro documento que visa à garantia dos direitos educacionais dos alunos surdos é a Lei n 13.146 - Lei Brasileira de Inclusão, de 2015. Em seu capítulo IV, "Do Direito à 
Educação", o poder público é incumbido de "assegurar, criar, desenvolver, implementar, incentivar, acompanhar e avaliar a”:

IV - oferta de educação bilíngue, em Libras como primeira língua e na modalidade escrita da língua portuguesa como segunda língua, em escolas e classes bilíngues e em escolas inclusivas;

(...)

XI - formação e disponibilização de professores para o atendimento educacional especializado, de tradutores e intérpretes da Libras, de guias intérpretes e de profissionais de apoio;

XII - oferta de ensino da Libras, do Sistema Braille e de uso de recursos de tecnologia assistiva, de forma a ampliar habilidades funcionais dos estudantes, promovendo sua autonomia e participação (BRASIL, 2015, Artigo 28)

É possível observar, em uma análise cuidadosa do disposto no Artigo 28 desta Lei, alguns pontos relevantes que corroboram, novamente, para a compreensão da pouca clareza do que significa educação bilíngue para surdos nos documentos oficiais de nosso país. O primeiro deles diz respeito à implantação desta educação em escolas ou classes bilíngues e em escolas inclusivas. Essa diferenciação explícita nos chama atenção, em especial porque desconsidera escolas bilíngues enquanto escolas também inclusivas, segundo os pressupostos presentes nos documentos internacionais. As Escolas para Todos caracterizam-se por serem escolas que abrangem a diversidade e são capazes de respeitá-la por intermédio de práticas e concepções que considerem as especificidades de aprendizagem de seus alunos. Nessa perspectiva, todas as escolas são, ou deveriam ser, escolas inclusivas, incluindo as escolas para surdos, que utilizam uma língua diferente, mas também atendem uma grande diversidade de alunos.

Compreende-se haver, portanto, a aceitação dos dois modelos, ficando subentendido a diferenciação existente entre ambas as propostas. Desse modo, a educação bilíngue pode ser concebida como aquela desenvolvida em espaços que têm a Libras como língua de instrução em escolas de surdos ou em classes organizadas para surdos no interior das escolas regulares. Se o Inciso IV da Lei $\mathrm{n}^{\circ}$ 13.146/15 for posto em diálogo com os Incisos I e II do Artigo 22 do Decreto $n^{0} 5.626 / 05$, entende-se que as escolas/classes bilíngues dizem respeito aos anos iniciais de escolarização, enquanto as escolas inclusivas para os anos finais. Nada impede, no entanto, que os alunos surdos estudem em escolas bilíngues para surdos em todos os níveis de escolarização, fato que significa um avanço em relação aos documentos anteriores. Esta 
prática não inviabiliza a presença de TILSP no interior da escola e, portanto, o previsto no Inciso XI do Artigo 28 desta Lei.

No entanto, causa estranheza o fato da oferta do ensino da Libras estar no mesmo Inciso que prevê o ensino do Sistema Braille e o uso de recursos de tecnologia assistiva, bem como a justificativa dada para o ensino da língua: “ampliar as habilidades funcionais dos alunos e promover sua autonomia e participação”. Considerando que o Braille constitui-se um sistema de leitura e escrita da língua portuguesa por meio de pontos em relevo, e que por tecnologia assistiva entende-se "produtos, recursos, metodologias, estratégias, práticas e serviços que objetivam promover a funcionalidade, relacionada à atividade e participação de pessoas com deficiência” (BRASIL, 2009b), infere-se que a Libras, ao ser equiparada ao sistema Braille e às tecnologias assistivas, distancia-se de seu status linguístico e assume um caráter instrumental, conforme já havia alertado Lodi (2013) sobre a forma como esta língua é compreendida pela Política de Educação Especial. Essa leitura justificaria, portanto, a compreensão equivocada que tem perpassado os documentos oficiais de que a Libras, concorrendo no mesmo espaço-sala com a língua portuguesa, materializada na presença de TILSP, poderia ser considerada uma prática de educação bilíngue.

Fernandes e Moreira (2014) ao analisarem o Decreto $n^{\circ} 6.571 / 08^{4}$, também apontam para o fato de ser atribuído a Libras o status de recurso de acessibilidade, ou seja, também nesse documento, de acordo com as autoras, há uma "indiferenciação valorativa entre uma língua que representa a produção histórico-cultural de uma comunidade minoritária e o conjunto de recursos físicos, técnicos e materiais que constituem as tecnologias assistivas” (p. 64). O que revela, ainda de acordo com as autoras, uma ambiguidade e polarização dos sentidos atribuídos à educação bilíngue para surdos nos diferentes documentos.

Strümer e Thoma (2015), a partir de concepções de Foucault, analisam seis documentos disponíveis na plataforma do MEC, destinados a orientar a educação bilíngue para surdos e suas práticas pedagógicas, e documentos escritos pela Federação Nacional de Educação e Integração dos Surdos (Feneis) são eles: A Educação Especial na Perspectiva da Inclusão Escolar: abordagem bilíngue na escolarização de pessoas com surdez (2010), Nota Técnica $n^{\circ}$ 34/2012, Relatório do Grupo de Trabalho designado pelas Portarias $n^{\circ}$ 1.060/2013 e n 91/2013 (2014), Nota de esclarecimento da Feneis sobre a educação bilíngue para surdos (2011), Carta-denúncia dos surdos falantes da Língua de Sinais Brasileira ao

\footnotetext{
${ }^{4}$ Documento dispõe sobre o atendimento educacional especializado.
} 
Ministério Público Federal (2011) e Proposta para elaboração de uma Política Nacional de Educação Bilíngue para Surdos (2012).

Em suas análises, as autoras apontam algo muito semelhante ao encontrado nos documentos analisados nesse capítulo: a polarização de sentidos nas acepções de educação bilíngue para surdos. Nos documentos do MEC há um grande foco na importância do Atendimento Educacional Especializado (AEE) para a garantia da acessibilidade dos alunos surdos na escola regular, sendo que a língua portuguesa é tida, nesses documentos, não como uma segunda língua dos alunos, mas como uma língua de instrução junto a Libras. Em contrapartida, nos documentos produzidos pela Feneis há um foco na importância da identidade surda e da incapacidade da sala comum em assegurá-la, ou seja, destaca-se a importância da língua vinculada à cultura para a garantia de uma educação de qualidade. É possível perceber, ao longo das análises, que a educação bilíngue para surdos é reconhecida como o melhor modelo educacional para esses sujeitos, entretanto, esse reconhecimento nem sempre vem acompanhado da clareza sobre o que ele significa. Essas variações se dão por conta das diferentes concepções do papel da língua no processo de escolarização de surdos e de educação presentes nos documentos.

As divergências existentes nos documentos oficiais que regem a educação de surdos atualmente, no entanto, não podem ser compreendidas de forma desvinculada do contexto mais amplo da educação brasileira. Nesse sentido, Garcia (2016), em seu artigo, ao relacionar as transformações políticas ao longo das últimas décadas na área de educação especial a partir da consideração do contexto educacional em seu sentido mais abrangente, pode contribuir para pensarmos as contradições existentes nas propostas de educação de surdos. De acordo com a autora, entre 1995 e 2010 duas “gerações de políticas na base neoliberal” (p. 12) foram implementadas e desenvolvidas em favor da educação especial na perspectiva inclusiva:

cada qual com suas particularidades, permeadas por uma conjuntura de ampliação do acesso à educação escolar ancorada na gestão da pobreza e na privatização da/na educação, seja pela participação direta ou indireta do setor privado na oferta educacional, seja da participação do setor privado como formulador ideológico e programático de uma pedagogia do capital para a educação escolar pública brasileira (p. 12).

De acordo com a autora, essas políticas têm repercutido: sobre a ampliação da relação público-privado (mediante a venda de equipamentos e a atuação das instituições filantrópicas); sobre a formação docente em cursos de educação à distância, para atender a 
demanda de professores necessários ao crescente número de atendimentos nas salas de recursos multifuncionais; e sobre o próprio trabalho docente, na medida em que para suprir as necessidades criadas por essas políticas estabeleceu-se a abertura de cargos inéditos na área com suas respectivas formas de contratações.

Uma das principais propostas dessas políticas, capaz exemplificar as consequências expostas por Garcia (2016), foi em 2003, a implementação das salas de recursos multifuncionais (SRMs) como um espaço privilegiado para o atendimento educacional especializado (AEE), que viria a ser consolidada, em 2008, com a Política Nacional de Educação Especial na Perspectiva da Educação Inclusiva. A implementação desses espaços buscou combater e eliminar as concepções tidas como segregacionistas que surgiram junto ao movimento integracionista no final do século passado, por esse motivo, tem como seu principal objetivo trazer para dentro da escola os alunos que por conta de suas capacidades eram direcionados a escolas ou salas especiais. Entretanto, como aponta a autora, essa tentativa de modelo único de educação, capaz de atender seu público diversificado, acabou por direcionar o atendimento especializado às características específicas de seus alunos e não a uma reflexão ou uma reorganização do trabalho docente regular ou especializado (no caso dos profissionais da educação especial). Dessa forma, a escola passa a ser responsável pelo atendimento de um público cujo corpo de professores já atuantes não estava preparado (ou não tinha formação) para recebê-los, resultando em uma urgência na contratação e formação de novos profissionais.

Os alunos surdos, conforme foi possível perceber nos documentos analisados nesse capítulo e nos apontamentos realizados por Garcia (2016) referentes a transformação da educação especial, são compreendidos nas políticas e documentos oficiais como público do atendimento educacional especializado, visto que a complementação em Libras e em português devem ser realizadas na sala de recursos. Além disso, são concebidos enquanto deficientes auditivos, atendidos pela educação especial. Em uma tentativa de combater as práticas segregacionistas, os ideais da educação bilíngue para surdos foram reinterpretados de diferentes maneiras pelas legislações na tentativa de construir uma escola capaz de atender a todos.

Essas reinterpretações, entretanto, não levam em consideração que a educação bilíngue para surdos não se caracteriza como uma série de práticas e métodos de ensino; sua concepção é muito mais profunda e tem a ver com a forma de se compreender os surdos e o uso social da língua de sinais (HARRISON; LODI; MOURA, 2005). Em consonância a esta concepção, 
Skliar (1999) afirma que esse modelo de educação pode ser definido enquanto um processo de reconhecimento político da surdez enquanto diferença. Dessa forma, não se trata da convivência de duas línguas no ambiente escolar, mas sim de uma forma de pensar a educação e, consigo, formas de se compreender o mundo e os sujeitos que se constituirão nesse espaço, a partir da língua de sinais.

Contrário a séculos de repressão, a educação bilíngue procura romper concepções que enxergavam surdos a partir de perspectivas binárias (SKLIAR, 1999), não mais aceitando classificações como capazes/incapazes, deficientes/eficientes; mas assumindo a diferença linguística e, consequentemente, a língua de sinais como essenciais para a constituição desses sujeitos. Somente nessa perspectiva é que os direitos (reconhecidos mundialmente) dos surdos ao uso de sua língua, assim como a uma educação de qualidade, podem ser garantidos. Nesse viés, a educação bilíngue não deve ser compreendida como uma ramificação da educação especial, visto que o discurso da deficiência mascara a questão política da diferença. Ela deve ser considerada um "paradigma oposicional” à educação especial (SKLIAR, 1999), entendida sempre no contexto da diferença linguística.

É a partir dessa concepção de educação bilíngue para surdos que será, a seguir, problematizado o papel da Libras como primeira língua nos ambientes escolares e no processo contínuo de constituição do sujeito surdo. 


\section{CAPÍTULO II}

\section{Concepção de língua e suas possibilidades para a educação bilíngue para surdos}

Na completude de sua obra Bakhtin buscou, principalmente, compreender o homem na relação com seus muitos outros. Geraldi (2013) denomina de “princípio da alteridade” a constante presença do outro na obra bakhtiniana, enquanto ser vivo e falante que, por meio do diálogo, participa ativamente da relação constitutiva estabelecida entre indivíduos. A língua o diálogo - é o meio pelo qual os indivíduos são significados e, também, pela qual significam o mundo e seus pares sociais; estes processos ocorrem ao longo de nossas vidas, nas muitas esferas sociais das quais participamos, inclusive da escolar. Não surpreende, dessa forma, que tenham momentos em sua obra em que o autor se dedicou a reflexão da língua dentro de um contexto mais pedagógico, tal é o caso de seu artigo “Questões de estilística no ensino da língua” (2013) em, em sua prática docente no ensino de russo para alunos russos, é capaz de elaborar reflexões sobre as possibilidades de articulação entre as formas gramaticais e os aspectos semânticos e estilísticos na utilização da língua; ou ainda em "Questões de literatura e estética: a teoria do romance” (1988) o autor se debruça sobre os processos de transmissão da palavra alheia existentes na escola e suas implicações no desenvolvimento de nossas próprias palavras.

Dessa forma, apesar de não ter se debruçado sobre a educação de surdos ou a língua de sinais, a completude da obra de Bakhtin permite que, a partir da linguagem na relação entre sujeitos, realizemos uma discussão sobre a própria ação educativa (independente do contexto em questão), pois como afirma Geraldi (2013), “não há educação fora da relação entre o eu e o outro” (p.15). Dessa forma, esse capítulo tem por objetivo a realização de uma reflexão sobre as bases que podem sustentar uma educação bilíngue para surdos, a partir dos conceitos bakhtinianos de linguagem e interação. 


\section{II.1 Palavra como signo ideológico e a formação do discurso interior}

Nesta seção, busca-se esclarecer o papel da palavra na organização e socialização humana, assim como questões referentes à formação do discurso interior de cada indivíduo.

Volochínov/Bakhtin ${ }^{5}$, em Marxismo e Filosofia da Linguagem, definem a palavra como um fenômeno, um produto ideológico capaz de refletir e refratar outra realidade que lhe é exterior. Para os autores, tudo que é ideológico possui um significado e remete a algo fora de si mesmo, caracterizando-se como signo. Todo signo está sujeito aos critérios de avaliação ideológica, pois o domínio ideológico coincide com o domínio do signo, sendo mutuamente correspondentes. "Ali onde o signo se encontra, encontra-se também o ideológico. Tudo que é ideológico possui um valor semiótico" (VOLOCHÍNOV/BAKHTIN, 2014, p. 33. Ênfase do autor). Assim, é impossível pensar em um signo que não nos remeta a nada, pois todo signo ultrapassa suas próprias particularidades, sendo capaz de refletir ou refratar realidades as quais se refere, carregando sempre uma avaliação e intenção ideológica daquele que o utilizou.

Signos, de acordo com Volochínov/Bakhtin (2014), só podem ser constituídos no terreno interindividual; portanto, entre indivíduos que estejam socialmente organizados, na medida em que sua criação se dá a partir do curso das relações humanas ali estabelecidas. Nesse sentido, entende-se que a consciência individual é, portanto, também um fato socioideológico, que só pode surgir e se afirmar como realidade por meio da encarnação material em signos.

Compreender um signo significa aproximá-lo de outros signos já conhecidos, por meio de uma "resposta a um signo por meio de signos" (VOLOCHÍNOV/BAKHTIN, 2014, p. 34), formando-se assim uma cadeia de criatividade e compreensão ideológica capaz de se deslocar de signo em signo, de forma única e contínua. Essa cadeia ideológica:

\footnotetext{
${ }^{5}$ Faraco (2003) ressaltou, em seu livro, o persistente problema de autoria em três principais textos produzidos pelo Círculo de Bakhtin: Freudismo, Marxismo e filosofia da linguagem e o Método formal nos estudos literários. Isso ocorreu, de acordo com o autor, porque os dois primeiros livros foram originalmente publicados com o nome de Valentin N. Volochínov e o último de Pavel N. Medvedev. Após uma pausa de quase trinta anos, os trabalhos de Bakhtin voltam a circular nos círculos acadêmicos na Rússia, o que resultou na republicação de seus textos em 1963 e 1965. Foi nesse contexto, conforme discutiu Faraco (2003) que o linguista Viatcheslav V. Ivanov afirmou, sem argumentos consistentes, que a autoria do Marxismo e filosofia da linguagem era apenas de Bakhtin e não de Volochínov e, como demonstrou Faraco, apesar de haver certa similaridade no conjunto de textos do Círculo, é possível perceber as diferenças nos objetivos e interesses pessoais de cada autor. Dessa forma, nesse trabalho, embora tenha sido mantida a autoria de ambos os autores, conforme presente na edição brasileira, foi atribuída autoria principal deste livro à Volochínov. Entretanto, nas referências bibliografas desse trabalho, manteve-se a nomenclatura utilizada pelo livro: Bakhtin/Volochínov.
} 
estende-se de consciência individual a consciência individual, ligando uma às outras. Os signos só emergem, decididamente, do processo de interação entre uma consciência individual e outra. E a própria consciência individual está repleta de signos. A consciência só se torna consciência quando se impregna de conteúdo ideológico (semiótico) e, consequentemente, somente no processo de interação social (VOLOCHÍNOV/BAKHTIN, 2014, p. 34).

Assim, o produto ideológico possui lugar nos signos criados pelos homens, situandose entre indivíduos socialmente organizados. A forma mais clara de materialização do produto ideológico e de seu papel contínuo de comunicação social é a linguagem, pois para Volochínov/Bakhtin (2014), é na e por intermédio da palavra que se encontram as formas básicas da comunicação semiótica. Além disso, a palavra carrega consigo a característica de ser um signo neutro. Isso acontece porque, diferente de outros sistemas de signos que têm um campo particular de criação ideológica, a palavra se encontra desvinculada de tais espaços, sendo capaz de preencher qualquer função ideológica específica. Isso significa que as mesmas palavras podem trazer entoações completamente diferentes: uma mesma palavra é capaz de elogiar ou agredir a depender do sujeito e de seu contexto.

Assim, se a palavra é um signo ideológico em essência, ela se constitui na base de nossa vida interior (é o material semiótico privilegiado do psiquismo). Isso significa que a própria consciência individual é algo puramente social, influenciada constantemente por fatores sociais externos. Entender a atividade mental como signo é entendê-la na sua capacidade de significação do mundo exterior e dela própria, existindo para o próprio indivíduo sob a forma de signos.

Seguindo essa linha de pensamento, Volochínov/Bakhtin (2014) afirmam que, desde que nascemos, estamos sujeitos ao sistema ideológico que nos cerca, estamos subordinados à suas leis e, conforme nos desenvolvemos e utilizamos signos conhecidos para compreender novos signos, nossa consciência se torna, ao mesmo tempo, sujeita (e pertencente) a um sistema particular de meu próprio psiquismo, que possui suas próprias regras. Esse sistema particular não é algo inato ao organismo; pelo contrário, ele é determinado ao longo da vida do sujeito pela "totalidade das condições vitais e sociais em que esse organismo se encontra colocado" (VOLOCHÍNOV/BAKHTIN, 2014, p. 60).

Portanto, quando nascemos, encontramo-nos inseridos em sistemas ideológicos que nos cercam, imersos em uma cultura e, ao longo de nossas vivências, de nossas experiências sociais, desenvolvemos um sistema ideológico particular (que permanece em seu caráter social). Ao mesmo tempo em que nos submetemos às regras dos contextos que nos cercam, 
submetemo-nos também às nossas próprias regras, que surgem sempre a partir da interação com o outro.

Isso acontece porque a compreensão de um novo signo está intrinsecamente relacionada com a situação em que ele tomou forma dentro de mim. Todo signo interior é acompanhado de uma experiência exterior, de uma situação social capaz de esclarecê-lo. Assim, cada consciência e forma de compreensão de novos signos são únicas, alterando-se de indivíduo para indivíduo, apesar de sempre possuir caráter social.

Para completar esse raciocínio a respeito da consciência individual, o autor afirma que, como a palavra é a base da vida interior, o "discurso interior" é constituído por monólogos completos que se assemelham a réplicas de diálogos, que não seguem "regras da lógica ou da gramática, mas segundo leis de convergência apreciativa (emocional), de concatenação de diálogos, etc... e numa estreita dependência das condições históricas da situação social e de todo o curso pragmático da existência" (VOLOCHÍNOV/BAKHTIN, 2014, p. 65. Ênfase do autor).

Assim, tanto o sistema particular de nossa consciência quanto a nossa atividade mental casual estão relacionadas (sempre) a experiências e relações sociais. Está sempre relacionada aos muitos outros que encontro em minha vida, que estão presentes até quando me encontro fisicamente sozinha. Para Volochínov/Bakhtin (2014, p. 116), "vemos a 'cidade e o mundo' através do prisma social que nos engloba", e por este motivo, é preciso levar em consideração que cada expressão individual está sempre vinculada a um horizonte social definido, além de ter um auditório social particular. Desse modo, torna-se impossível pensar em língua/discurso sem a compreensão da natureza ideológica do signo.

\section{II.2 Libras como primeira língua e o papel dos outros no processo de constituição do sujeito}

Volochínov/Bakhtin (2014) discutem as formas de compreensão da língua para diferentes linhas de estudo. Os autores se posicionam contra a orientação por eles denominada subjetivismo individualista, por esta conceber a língua como resultado da consciência individual e, portanto, desvinculada de seu caráter social; do mesmo modo, opõem-se à que chamaram objetivismo abstrato, que compreende a língua como um sistema normativo que orienta as enunciações dos falantes. 
Para os autores, de forma contrária ao que ambas as vertentes acima assinalam, a língua só pode ser compreendida em seu caráter concreto e vivo, ou seja, sempre vinculada àqueles que a utilizam. Por este motivo, a língua se caracteriza como um fenômeno puramente histórico, em constante evolução, em constante transformação. As enunciações, que materializam a língua em discurso, são de natureza social, estão sempre orientadas em relação à um outro. Assim, um enunciado nunca é dito no vazio, ele se constitui em um elo da cadeia infinita de comunicação verbal. Um enunciado é sempre uma resposta a outro, ao mesmo tempo em que está sempre antecedendo uma resposta. Nesse fluxo contínuo a língua permanece sempre em movimento, sempre em evolução.

Essa orientação garante que a palavra não seja compreendida como imóvel e imutável (como quando inserida em dicionários), mas sim carregada de um conteúdo, de um sentido ideológico ou vivencial. Portanto, a língua se encontra sempre inseparável de seu conteúdo ideológico ou relativo à vida, podendo ser compreendida em sua realidade concreta, nas infinitas enunciações de diferentes sujeitos, em distintos contextos sociais. Consequentemente, por estar intrinsecamente relacionada à ideologia e à vida, ela se encontra inseparável de valores culturais, de sistemas ideológicos, de formas de compreender e significar o mundo que nos cerca.

Língua e cultura encontram-se, portanto, entrelaçadas. Ser usuário de uma língua significa possuir formas de significação de mundo intrinsicamente relacionadas às culturas daqueles que a utilizam. Mas como um indivíduo assimila essa língua?

Volochínov/Bakhtin (2014) discordam da concepção de que a língua é algo imutável transmitido de geração à geração, como se a língua se encontrasse fora do fluxo de comunicação verbal. Compreender e assimilar a língua, para os autores, está longe de ser algo inato ou passivo; muito pelo contrário, é algo sempre ativo, já que compreendemos o enunciado do outro ativamente com nossas próprias palavras. Entende-se assim, que ao sermos receptor do outro, simultaneamente, no ato de compreensão, elaboramos, com nossas próprias palavras, uma resposta (ainda que essa não seja sonorizada). É colocando nossas contrapalavras em relação às do outro, que somos capazes de compreender os sentidos particulares de cada enunciado e, consequentemente, de nos aproximarmos e dominarmos as diferentes formas de linguagem.

A língua, portanto, não se transmite aos indivíduos, 
ela dura e perdura sob a forma de um processo evolutivo contínuo. Os indivíduos não recebem a língua pronta para ser usada; eles penetram na corrente da comunicação verbal; ou melhor, somente quando mergulham nessa corrente é que sua consciência desperta e começa a operar (VOLOCHÍNOV/BAKHTIN, 2014, p. 111).

A assimilação da primeira língua durante a infância é, portanto, um processo de imersão progressiva da criança na comunicação verbal. Antes de nascermos, outros indivíduos já se encontram inseridos nesse fluxo e, pouco a pouco, por meio da interação dialógica, penetramos e nos constituímos na e pela língua.

A primeira língua é aquela por meio da qual o indivíduo significa o mundo ao seu redor e é significado por ela, constituindo-se, portanto, pela e na língua. É aquela com a qual ele se identifica e que outros o identificam. No caso dos surdos, a primeira língua não é, necessariamente, aquela que ele terá contato ao nascer, ou a língua de seus pais, considerando que a maior parte dos surdos são filhos de pais ouvintes que não (ou pouco) conhecem a Libras. Assim, apesar de estarem cercados de sujeitos falantes da língua portuguesa, de viverem situações e estarem imersos em contextos sociais que a utilizam, os surdos são incapazes de compreendê-la em sua plenitude nos anos iniciais de vida. Isso porque se trata de uma língua oral, cuja base se encontra no som. No entanto, não se pode negar que mesmo com uma compreensão reduzida da língua portuguesa, nas relações cotidianas entre pais e filhos, formas outras de comunicação acabam sendo desenvolvidas, muitas vezes pautadas em gestos e expressões de afeto que tomam como base a linguagem oral; e embora estas formas não se constituam língua, acabam por inserir a criança no mundo da linguagem, assegurando uma comunicação utilizada para a satisfação de necessidades e para o aconchego familiar.

Estas distintas maneiras de se comunicar, podem ainda propiciar que alguns surdos sejam capazes, por intermédio da oralização, de identificar algumas palavras e de se comunicarem, entretanto, dificilmente serão capazes de compreender a língua portuguesa no fluxo da comunicação verbal, da forma como é possível a um ouvinte. Ou seja, a criança surda pode ser capaz de identificar e reproduzir palavras dicionarizadas (imutáveis), entretanto não será capaz de compreendê-las enquanto signo ideológico social, com significações sempre construídas entre indivíduos, a depender do contexto e das intenções dos locutores. É apenas a partir da assimilação da Libras como primeira língua que a compreensão da palavra enquanto signo ideológico se dá. É a partir de uma língua de materialidade diferente que surgem possibilidades de penetração na corrente de comunicação verbal, de interações concretas mediadas pela linguagem. 
Nesse contexto, torna-se importante refletir ainda sobre a importância dos muitos “outros” envolvidos no processo de escolarização e de socialização das crianças surdas, em especial o papel que o sujeito professor assume na relação com o seu aluno, pois a forma como esse professor o enxerga (e vice-versa) terá consequências na forma como o aluno constrói conhecimento e se relaciona com o mundo que o cerca.

Freitas (2013) compreende a relação entre professor e aluno, também a partir de preceitos bakhtinianos, como uma relação dialógica, "em que se enfrentam dois sujeitos em processo de construção compartilhada de conhecimento" (p. 97). A autora define o ensino e a aprendizagem como partes de um mesmo processo, no qual professor e alunos participam ativamente. Isso ocorre porque, para Volochínov/Bakhtin (2014), o ato de compreender é algo ativo, diferente de uma transmissão de uma via a outra (sem barreiras). Para os autores, "qualquer tipo genuíno de compreensão deve ser ativo, deve conter já o germe de uma resposta" (p. 136). Isso significa que compreender a enunciação de outrem é opor à palavra do outro uma contrapalavra, é trazer o enunciado de outrem para nosso discurso interior (banhados durante toda a vida de discursos alheios) e contrapô-lo com nossas contrapalavras.

Freitas (2013) afirma que esse é um processo de significação que só é possível por meio do processo de compreensão responsiva ativa, que supõe dois sujeitos obrigatoriamente falantes, ambos com direito a voz. Para a autora, "essa compreensão ativa é criadora, pois completa o texto do outro, tornando-se um processo de co-criação dos sujeitos" (p. 98). Assim, tanto aquele que se encontra na posição de ensinar, quanto aquele que ocupa a posição de aprender, cria novos significados para o conhecimento produzido. Nessa interação, ninguém sai da mesma forma que entrou, sempre há a possibilidade de transformações ou reafirmações.

Isso não se resume unicamente aos saberes universais que a escola busca ensinar; pelo contrário, desde o nascimento estamos envoltos em um universo ideológico, estamos sempre cercados de palavras alheias. Para Freitas (2013), além de possuirmos nossas próprias palavras (que constantemente utilizamos para compreender a palavra do outro) nos encontramos imersos nas palavras do outro:

E toda a minha vida [...] é uma reação às palavras do outro (uma reação infinitamente diversificada), a começar pela assimilação delas (no processo inicial do discurso) e terminando na assimilação das riquezas da cultura humana (expressas em palavras ou em outros materiais semióticos). A palavra do outro coloca diante do indivíduo a tarefa especial de compreendêla (BAKHTIN, 2011, p. 379). 
Neste processo de compreensão responsiva ativa, ao longo da vida, as palavras alheias entram em conflito com as palavras já assimiladas pelo indivíduo, causando assim, transformações em sua forma de pensar, até que, eventualmente, as palavras alheias passam a fazer parte de seu novo discurso, dessa vez, com novas tonalidades volitivo-emocionais. Como consequência, as mais diversas formas que os outros o concebem são capazes de transformá-lo, em especial no período que ele está em processo de desenvolvimento da linguagem, considerando-se que a criança se encontra nos primeiros momentos de significação do mundo e de si, por meio da língua e das interações.

Ao enunciarmos, orientamos sempre nossas palavras em função de um interlocutor em um contexto específico, minha enunciação sempre responde a alguém e precede a resposta de alguém. Além de sua orientação, a palavra sempre é a expressão de um em relação a um outro; é apenas por meio e na enunciação que consigo definir quem eu sou em relação ao outro.

A palavra é sempre determinada pelas relações sociais e, sem essa orientação social, de caráter apreciativo, não existiria atividade mental. É a multiplicidade de sentidos existentes que faz da palavra uma palavra, que faz dela um signo ideológico capaz de habitar a consciência individual. Por este motivo, cada enunciação tem um sentido próprio (ainda que possua as mesmas "palavras") que sempre dependerá do tema (determinado por formas linguísticas e por elementos não verbais da situação) e da situação histórica concreta em que foi realizada. O significado de cada enunciado se encontra à mercê de uma significação para a realização do tema. Esses dois elementos da produção de sentido se encontram intrinsecamente relacionados, sendo impossível traçar uma fronteira entre eles. Há, no entanto, um terceiro elemento, que se encontra incluso na palavra: o acento de valor, de caráter apreciativo.

O acento de valor, ou a entoação expressiva, é sempre determinado pela situação imediata e suas circunstâncias. Segundo Volochínov/Bakhtin (2014, p.139), pode-se "pronunciar a mesma palavrinha favorita com uma infinidade de entoações diferentes, conforme as diferentes situações ou disposições que podem ocorrer na vida"; portanto, cada enunciação viva possui um sentido e uma orientação apreciativa, devendo-se sempre levar em conta a apreciação social para a compreensão de uma determinada enunciação.

Por fim, Bakhtin (1988), ao discutir o papel da assimilação das palavras de outrem para a evolução ideológica do ser humano, explicita os impactos dos encontros com discursos alheios ao longo de toda a vida do homem. Nas interações, de acordo com o autor, as palavras 
de outrem tentam “definir as próprias bases de nossa atitude ideológica em relação ao mundo e de nosso comportamento” (p.142) e isso acontece através da palavra autoritária e da palavra persuasiva.

A palavra autoritária possui seus valores ideológicos já historicamente reconhecidos (usualmente relacionadas a esferas extremamente hierárquicas como a religiosa, a política, a escolar, etc.); não há, nela, a possibilidade de confrontos, exigindo de nós apenas o seu reconhecimento e assimilação total ou a sua completa negação. Quando já assimiladas ou negadas, a palavra autoritária tem a capacidade de organizar, em torno de si, outras palavras, mas nunca a de misturar-se a elas. Ressoa, nela, uma única voz, a qual é impossível estabelecer um diálogo transformador.

A palavra interiormente persuasiva, por sua vez, é, de acordo com Bakhtin (1988), essencial para o desenvolvimento e transformação da consciência individual. Ao contrário da palavra autoritária, que permanece isolada e imóvel em nossa vida ideológica, quando assimilada, a palavra persuasiva, necessariamente, se entrelaça com as nossas palavras, organizando-as, transformando-as em um processo eterno e infinito. Esta palavra inacabada, logo, de sentidos inesgotáveis, permite que seja inserida em inúmeros contextos, gerando as mais criativas respostas à ela.

A palavra persuasiva se une as minhas palavras e transforma minha vida ideológica interior, ou seja, transforma as formas pela quais compreendo e significo o mundo ao meu redor. As palavras persuasivas não tem um fim em mim, ela continuam inacabadas, podendo sempre revelar novas possibilidades ao ser colocada em novos contextos dialogizados, ao se relacionar, inclusive, com novas palavras interiormente persuasivas.

Dessa forma, para Bakhtin (1988), essa possibilidade de autonomia da consciência individual é um tenso conflito em nosso interior, uma arena de lutas, na qual diferentes pontos de vista verbais e ideológicos buscam a supremacia.

Um exemplo, citado pelo autor, para explicitar o funcionamento dessas palavras envolve dois métodos de ensino tradicionais, ainda presentes nas aulas de ensino de primeira língua: a reprodução “de cor” - a repetição - e “com suas próprias palavras” - um exercício em que o aluno deve misturar suas próprias palavras com a voz do autor, criando um novo texto de caráter misto e bivocal, no qual as duas vozes se encontram presentes, sem que as originalidades dos autores se percam, ou seja, a palavra do outro deve entrelaçar-se em suas palavras, transformá-las, criando um texto inteiramente novo. 
Esta discussão remete aos muitos sentidos que podem estar presentes em sala de aula, em especial quando, não raramente, um professor "define" um aluno. Para Goulart (2013), a multiplicidade de sentidos implica que as palavras podem servir tanto à opressão quanto à libertação. Essas também são palavras persuasivas, capazes de transformar e definir a consciência individual do aluno, capaz de mudar, inclusive, a forma como este se enxerga, em especial nos anos iniciais de vida, visto que, de acordo com Bakhtin (1988), as diferenciações entre as nossas palavras e as palavras dos outros acontecem relativamente tarde. No cotidiano escolar, pode-se definir um aluno como incapaz, como deficiente, ainda que não se tenha a intenção de ofende-lo ou de menospreza-lo; constantemente, o professor mostra ao seu aluno o que ele pensa em relação a suas capacidades. A forma como enxerga e define o outro transversaliza os discursos, carrega suas palavras com valores apreciativos, ainda que de forma implícita e, nos sentidos em circulação nestes enunciados, o professor pode levantar barreiras que o aluno, dificilmente, consegue superar. Do mesmo modo, se o docente concebe seu aluno como capaz, se acredita em seu potencial, seus enunciados também carregam-se destes valores, que são percebidos pelos sujeitos, já que o outro está presente em todos os momentos de significação do mundo que o cerca.

Outro conceito de Volochínov/Bakhtin (2014) que permite pensar a importância do outro no processo de constituição do eu é o de excedente de visão. Amorim (2012), ao analisar o conceito de cronotopia e exotopia em Bakhtin, afirma que "ninguém é herói de sua própria vida" (p. 97). O outro é capaz de sempre me ver como um pano de fundo que me foge a visão, um pano de fundo que me é inacessível; o inverso também acontece: eu sou capaz de ver no outro algo que ele não vê. Amorim (2012) afirma:

O outro que está fora de mim é quem pode dar uma imagem acabada de mim e o acabamento, para Bakhtin, é uma espécie de dom do artista para seu retratado. O acabamento aqui não tem sentido de aprisionamento, ao contrário, é um ato generoso de quem dá de si. Dar de sua posição, dar aquilo que somente sua posição permite ver e entender (p. 97).

Para Freitas (2013), o lugar singular que cada um de nós ocupamos é uma contraposição entre o eu e o outro, pois "o outro é constitutivo do eu, sem o outro eu não posso Ser" (p. 104). É por meio do encontro com muitos outros (cada um deles único), do seu excedente de visão e da minha compreensão responsiva ativa dos enunciados alheios, que me torno quem sou. 
Ao se pensar em uma escola regular, os vários outros que me permitem tornar-me quem sou estão presentes em todos os momentos e em todos os enunciados em circulação na esfera; enunciados que são compartilhados na medida em que falamos a mesma língua. Compartilha-se também, neste contexto, culturas, representações e recortes de mundo que nos influenciam a nos tornarmos seres únicos. Nesse sentido, reafirma-se que a língua é a base pela qual se estabelecerão todas as relações no ambiente escolar, relações estas que servirão para a constituição do sujeito. Este mesmo processo deveria acontecer com os alunos surdos; no entanto, muitas vezes, eles se encontram em um ambiente no qual os outros não compartilham uma língua e, consequentemente, da mesma cultura.

Nesse sentido, a proposta educacional bilíngue torna-se o modelo educacional privilegiado para surdos, desde que se considere, na escola, a importância das interações entre os alunos e os demais sujeitos presentes neste espaço, e se tenha clareza da importância de se compartilhar a língua. Na educação infantil e nos anos iniciais de escolarização, o contato com a língua e com seus usuários é essencial para que a criança possa se inserir no fluxo de comunicação verbal. Portanto, o professor regente dos anos iniciais de salas bilíngues para surdos não pode ser qualquer um. É um pré-requisito que este docente possua formação inicial em pedagogia, esteja inserido no universo cultural constitutivo e constituído pela Libras, que ele se identifique como sujeito surdo e que consiga se relacionar, desta forma, com as crianças. Nesse sentido, seria preferível que este professor fosse surdo.

Entretanto, reconhece-se que apenas um professor seja insuficiente para o contato dos alunos com a língua, com a cultura ou com a comunidade surda. Concordamos com Geraldi (2013) sobre o fato de que a "a experiência humana diferente (não a desigualdade) favorece o processo de humanização" (p. 14) e que, com apenas um professor, o contato com a diversidade da experiência humana, mesmo com uma língua compartilhada, seja impossível. É importante que o aluno surdo não esteja isolado na escola, que não possua uma única referência sobre o ser surdo, mas sim várias, para que possa viver diferentes sentidos e significações de mundo, possibilitados por sua língua e pela convivência, e, assim, desenvolver-se de forma plena.

Como é possível perceber, pensar a educação em outra língua implica em muito mais do que apenas forçar o convívio de duas línguas no interior de uma mesma sala/escola. É apenas por meio da compreensão de que sem linguagem não há educação, não há desenvolvimento cognitivo ou social que se pode perceber o peso da história, o peso dos 
séculos em que surdos foram forçados por ouvintes a utilizar uma língua oral da qual não poderiam fazer parte.

\section{II.3 A Libras e os processos educacionais: a educação bilíngue para surdos}

Pensar em uma educação que tenha a Libras como primeira língua não é algo tão simples como pressuposto nos documentos oficiais. Para que isso realmente seja possível, a Libras deve ser concebida e assumida como o centro de todas as atividades realizadas no ambiente escolar, por meio de um currículo que pense a Libras como primeira língua e que reconheça a sua importância. Apenas com a constante presença da língua de sinais é possível perceber a escola enquanto, também, uma comunidade dessa língua (KYLE, 1999). É somente ao compreender a importância da língua no processo de desenvolvimento e constituição das subjetividades dos indivíduos, que se torna possível pensar a Libras como a língua primeira na escola e na vida. Isso não implica, entretanto, em uma adaptação das metodologias e propostas educacionais desenvolvidas para ouvintes, mas sim colocar a Libras como ponto de partida, pensar formas de ensinar, de compreender, de interagir a partir desta língua.

Apenas por meio da língua de sinais (e não apenas utilizá-la como um instrumento para se alcançar o ensino do português escrito) é que a escola será capaz de cumprir seu papel na vida do sujeito surdo, ao se considerar que a escola não tem como função a transmissão de conhecimentos imóveis e imutáveis. Nesse sentido, concordamos com Sposito (2004), quando a autora afirma que a instituição escolar tem uma função socializadora, que vai além de apenas garantir a transmissão sistemática da parcela da cultura humana acumulada e das competências necessárias à sua incorporação. A escola, enquanto instituição socializadora, ensina em seu cotidiano, nas relações interpessoais, como “estar junto” e como “viver junto”, dois aspectos essenciais para a vida em sociedade, para a convivência em qualquer esfera da atividade humana e, também, para as relações entre pares e grupos com os quais o aluno venha a se identificar.

Para Kramer (2013), a educação deve ser pensada como resposta responsável. Suas ideias vão ao encontro das de Sposito (2004), ao afirmar que é papel da escola garantir o conhecimento do mundo (em meio à ambivalência do ato educativo escolar, espaço em que, ao mesmo tempo em que se vive a pluralidade cultural, busca-se garantir a construção de um conhecimento universal) e o reconhecimento do outro. A autora não compreende a escola 
como uma mera transmissora ou reprodutora de saberes, mas como uma instituição que possui um importante papel no processo (eterno) de socialização de seus alunos.

Kramer (2013) afirma ainda a importância que o outro desempenha na produção de nossos próprios conhecimentos. Em sintonia com esses pensamentos, Geraldi (2013), que também ao pensar a educação a partir de princípios de Bakhtin, afirma ser o diálogo "a maneira criativa e produtiva do eu se aproximar com suas palavras às palavras do outro, construindo uma compreensão que, por não ser de mero reconhecimento dos signos usados, é sempre uma proposta, uma oferta, uma resposta aberta a negociações e a novas construções" (p. 15).

Assim, a língua assume papel central nos processos de compreensão e construção do conhecimento (tanto universal, quanto dos diversos contextos particulares em que estamos inseridos), mas também é por seu intermédio que é possível a interação entre indivíduos. Nos escritos do Círculo de Bakhtin, o caminho da aproximação possível entre o eu e o outro é o diálogo, e é nessa relação com o outro, por meio da linguagem, que somos capazes de criar novos sentidos. Essa é uma relação de alteridade, na qual ninguém sai exatamente como entrou, assim como os sentidos e as pessoas também são capazes de se transformar e transformar o outro (GERALDI, 2013). É, portanto, apenas na relação com o outro que sou capaz de, através do diálogo, transformá-lo e de me transformar.

O contato com a língua pode ocorrer no interior das comunidades surdas, mas é papel da escola assegurá-lo a partir do período de obrigatoriedade escolar da criança, visto que esta instituição se caracteriza como um espaço privilegiado de garantia de interações (o mais cedo possível) com e pela língua de sinais. Caso isso não ocorra, as crianças serão privadas de plenas interações linguísticas, relações estas que são asseguradas aos ouvintes desde o nascimento. É apenas pela garantia do desenvolvimento da linguagem, o mais cedo possível, que crianças surdas se desenvolvem em equidade aos ouvintes.

É importante ressaltar ainda que o desenvolvimento dos alunos não se restringe à sala de aula; as interações, as relações que constrói ao longo de seus anos na instituição, extrapolam os limites da sala de aula; assim sendo, parece-nos óbvio o fato de que a língua deveria acompanhar os estudantes em qualquer espaço. Entretanto, o que pode vir a acontecer, ao se considerar as contradições presentes em nossas legislações, é que o espaço destinado a essa língua muitas vezes se limite às salas de aula, ou salas de atendimento educacional especializado, nas interações entre alunos surdos e seus intérpretes. Um espaço que propõe o 
convívio de línguas precisa considerar que a relação entre elas nunca são harmônicas, pois envolvem relações de poder que influenciam nas interações entre falantes.

Pensar uma educação bilíngue para surdos envolve, portanto, pensar nas relações conflituosas e tensas entre a Libras e o Português. Nesse sentido, desenvolver uma educação que permita a reflexão em e da primeira língua para alunos surdos pressupõe ainda a consideração dos gêneros do discurso, aspecto que será discutido no capítulo a seguir. 


\section{CAPÍTULO III}

\section{Os gêneros do discurso}

\section{III.1 Os gêneros discursivos nas esferas escolares}

A língua, como discutido antes, está presente em todos os momentos da vida humana. Ao nascermos somos imersos na linguagem, e é por meio dela que os muitos outros de nossas vidas nos significam, significam inicialmente nosso mundo e, posteriormente, participam de nossas significações de mundo. Ideológica em essência, a língua se encontra, também, vinculada a todos os processos escolares e a todas as relações estabelecidas dentro e fora da escola.

A escola, em especial no caso dos surdos, exerce um papel privilegiado para uma vivência linguística em sua pluralidade, visto que nesta frequentarão sujeitos vindos de diferentes contextos de vida. Na educação infantil, a prioridade recai na assimilação da língua e, consequentemente, das muitas linguagens nas quais as crianças se encontram e se encontrarão inseridas. A brincadeira, seja ela dos primeiros meses de vida ou até os cinco anos de idade, é sempre perpassada pela língua, em especial nos jogos protagonizados ${ }^{6}$ ou nos jogos imaginários, cujo uso da língua se encontra mais avançado e permite que a criança assimile as diferentes linguagens, as diversas formas de se posicionar e de significar o mundo ao seu redor.

Góes e Lopes (2006) afirmam que é por intermédio dos jogos imaginários que as crianças podem experimentar os dizeres que caracterizam as relações humanas nas diferentes esferas sociais, experienciando, desse modo, distintos gêneros discursivos. Nessa vivência, a criança pode explorar enunciados e os modos de enunciar apropriados a certos espaços da cultura, exigindo que ela leve em consideração suas regras específicas do que e de como dizer. Nessa perspectiva, as autoras apontam a possibilidade de um trabalho com gêneros discursivos que tenha início desde a educação infantil, levando a criança a perceber, desde cedo, a pluralidade dos dizeres vinculados as muitas esferas de atividade humana.

Posteriormente, nos anos iniciais e finais do ensino fundamental, prioriza-se um exercício de reflexão sobre a primeira língua das crianças. Volochínov/Bakhtin (2014)

\footnotetext{
${ }^{6}$ Nomenclatura utilizada por Elkonin (2009) em seu estudo sobre a principal atividade de desenvolvimento de crianças de quatro a seis anos de idade.
} 
explicitam que, após ter assimilado sua primeira língua, ao "falante nativo" interessa o uso da língua em contextos possíveis e particulares, das várias enunciações em sua prática linguística nos diferentes contextos de vida e não um conjunto normativo de regras abstratas; afinal, para o aluno, "a língua, no seu uso prático, é inseparável de seu conteúdo ideológico ou relativo à vida" (p. 99).

Desse modo, a forma como é pensada historicamente o ensino de primeira língua baseia-se em concepções equivocadas, pois não se trata da transmissão mecânica da língua; na realidade, ao longo de sua vida, o sujeito assimilará a língua a partir das muitas interações que vive e, lentamente, penetrará na cadeia verbal interrupta de enunciações. O termo que se acredita ser mais coerente seria processo de reflexão da primeira língua, entender as escolhas que se faz ao enunciar e as infinitas possibilidades existentes para a construção do projeto enunciativo. Cabe, então, nos anos iniciais e finais do ensino fundamental e no ensino médio a realização dessa reflexão, para que o sujeito possa, na e por meio da língua, posicionar-se nas mais diversas situações sociais. Mais do que dominar o sistema normativo de regras, deve-se possibilitar, aos alunos, o saber utilizá-lo em contextos reais e em relação com a vida.

Nesse sentido, o conceito de gêneros do discurso desenvolvido por Bakhtin pode nos ajudar a refletir sobre um ensino de língua que considere o enunciado em sua completude. Para que possamos compreender o conceito de gêneros do discurso em Bakhtin, é preciso levar em consideração as discussões realizadas anteriormente neste trabalho a respeito da concepção de língua para este autor: do discurso enquanto a língua em sua integridade concreta e viva, que se materializa por meio de enunciações, sendo, em essência ideológica. Além disso, retomamos que nenhum enunciado se encontra isolado, sendo único ou monológico, visto que cada enunciado é um elo na cadeia de comunicação verbal. Todo enunciado, portanto, é uma resposta a outros e visa uma nova resposta.

Em seu texto Os Gêneros do Discurso, Bakhtin (2011) afirma que o uso da língua está sempre vinculado a situações concretas, que ocorrem em uma infinidade de esferas de atividade humana e que permite a criação de uma multiplicidade de sentidos atribuídos à um mesmo objeto, o plurilinguismo. Os falantes que circulam por essas esferas acabam por elaborar enunciados relativamente estáveis, os quais o autor denominou de gêneros do discurso. Relativos, ao se levar em conta que os gêneros do discurso se relacionam intrinsecamente com as esferas de atividade humana que os estabelecem, e que se encontram em constante transformação, fato que acaba por determinar também que os gêneros sejam infinitos e estejam em permanente mutação. 
Cabe ressaltar ainda que esses enunciados relativamente estáveis refletem as condições específicas e as finalidades das esferas de atividade por intermédio de seus conteúdos temáticos, estilo verbal e construção composicional. Esses três elementos se fundem no todo do enunciado (a partir das características específicas de construção do mesmo) e são marcados pela esfera da comunicação verbal. Entretanto, como afirma Sobral (2009), é preciso compreender que a participação do gênero e seus elementos só existe enquanto um ato sóciohistórico concreto, criando uma totalidade de sentidos muito maior do que apenas a soma dos componentes que convergem para a construção do enunciado.

Nessa inter-relação entre vida e língua, em que são formados enunciados relativamente estáveis (entendidos aqui como uma unidade aberta, sempre passíveis de sofrerem transformações ou se reafirmarem a partir do uso de seus falantes), é que a língua é capaz de penetrar a vida e, simultaneamente, por meio deles, a vida é capaz de penetrar na língua (BAKHTIN, 2011, p. 265).

Machado (2012) ressalta ainda que os gêneros não devem ser compreendidos como uso com uma intenção deliberada, mas dimensionado como uma manifestação da própria cultura. Nessa perspectiva, a autora afirma que os gêneros são elos de uma cadeia capaz de unificar e dinamizar as relações interpessoais, assim como os sistemas de linguagens. A autora afirma ainda que o conceito de gênero do discurso não pode ser pensado desvinculado de sua dimensão "espaçotemporal" (p. 158), ou seja, fora das situações cronotópicas particulares e recorrentes.

Ao pensarmos que os gêneros são formados nas infinitas esferas de comunicação humana e enquanto um elemento indissociável da cultura, podemos concluir que eles, assim como a língua (e vinculados à ela), também perpassam todas as relações comunicativas entre sujeitos. Dessa forma, Bakhtin (2011) afirma que todos os enunciados dispõem de uma forma padrão e relativamente estável de estruturação de um todo. Isso significa dizer que nos utilizamos de gêneros do discurso sem suspeitar de sua existência e influência na construção dos enunciados. Inclusive, para o autor, somos capazes de usá-los muito antes de começarmos os estudos das formas prescritivas da língua (como a gramática). Pode-se afirmar, portanto, que o processo de desenvolvimento de linguagem implica, necessariamente, na aprendizagem das formas de estruturação dos enunciados e, logo, dos gêneros do discurso.

No entanto, algumas características da construção dos enunciados precisam ser levadas em conta. Por meio do enunciado, somos capazes de expressar e exteriorizar nosso universo interior e a compreensão desses enunciados só pode se dar por intermédio da 
compreensão responsiva ativa. Assim, ao se analisar um enunciado é preciso entendê-lo sempre na relação entre sujeitos, em contextos específicos, que respondem a algo.

Entretanto, apesar de serem elos da cadeia ininterrupta de comunicação verbal, é possível perceber fronteiras claramente delimitadas entre os enunciados concretos: a alternância de sujeitos falantes permite que eles tenham um começo e um fim. Nessa alternância (e, consequentemente, na relação entre o locutor e seus parceiros da comunicação verbal, em uma esfera específica) é possível perceber o acabamento específico do enunciado, assim como o tratamento exaustivo e a apreciação valorativa do locutor. No intuito, no querer dizer do locutor em relação a um objeto, é que se determinará o gênero em que o enunciado será estruturado, o que Bakhtin (2011) chamará de estilo do enunciado.

Assim, estruturar um enunciado é, para o autor, diferente de se estruturar uma oração. No segundo caso, basta haver uma completude gramatical para garantir esta formação. A oração é entendida totalmente desvinculada da realidade, logo de seus falantes, e não abrange a construção de um real sentido. Em contrapartida, o enunciado não é resultado de uma junção de formas prescritivas da língua; ao contrário, ele é construído na relação entre interlocutores, em um contexto de comunicação verbal específico, e traz consigo a relação valorativa que o locutor estabelece com o objeto, além de sua intenção específica para o enunciado. A oração é incapaz de gerar uma atitude responsiva ativa, pois ela é desprovida de uma situação e de um falante concretos.

Essa apreciação valorativa do locutor sobre o objeto é o que Bakhtin (1988; 2011; 2014) denomina de entoação ou entonação. Bakhtin (1988) afirma que o caminho entre o sujeito e seu objeto é composto de um meio flexível, difícil de ser penetrado, repleto de discursos alheios sobre o mesmo objeto. É em meio a essa relação mútua (indivíduo - objetos - discursos alheios) que o discurso pode se individualizar e elaborar-se estilisticamente. É nesse percurso e nessa relação dialógica com o discurso de outrem que o locutor realiza a escolha dos recursos linguísticos e do gênero, de forma a lhe permitir exteriorizar seu discurso interior e manter sua individualidade.

Nesse sentido, Faïta (1997) afirma que todo enunciado "se dirige prioritariamente para a atividade do outro em função do que a orientação apreciativa do locutor permite julgar ou pré-julgar" (p. 170. Ênfase do autor). Dessa forma, podemos reafirmar a importância de se compreender o enunciado sempre em suas condições concretas de uso e de sentido, realizada na relação com o outro, considerando o modo como os locutores se relacionam com seus temas e com seus parceiros da comunicação verbal. 
É na vivência com a diversidade das formas de dizer que somos capazes de construir um enunciado único, repleto de individualidade. Bakhtin (2011) afirma ainda que, ao utilizarmos a língua, não o fazemos por meio de palavras "isoladas", dicionarizadas; ao elaborarmos um enunciado buscamos palavras em contextos reais de uso, com sentidos específicos presentes em enunciados concretos (produzidos em seus respectivos contextos e dentro de relações específicas) e essa seleção ocorre sempre levando em consideração às especificidades dos gêneros ligados as esferas de comunicação verbal.

Todo enunciado é materializado por meio dos gêneros discursivos, entretanto, essa característica não resulta em uma normatização da língua. Faïta (1997) problematiza a ideia errônea de que todos os sujeitos adquirem os gêneros de formas idênticas, quando, na realidade, cada um os assimilará de acordo com suas experiências e situações específicas, garantindo formas particulares de se enunciar nos diferentes gêneros, marcadas pelas colorações sociais de cada encontro com outros locutores.

Os gêneros do discurso se caracterizam, portanto, como formas normativas da língua a partir das combinações que o enunciado realiza, mas, conforme Faïta (1997), ele também se exprime em individualidades resultantes da livre concepção que cada locutor faz de seu "projeto discursivo" (p. 171). O autor discute ainda que é nessas normas, nas restrições que regem as formas, que se materializa a multiplicidade de trocas constitutivas de toda atividade humana. Dessa forma, é possível afirmar que a descoberta de nossa individualidade se dá de acordo com o grau de clareza das relações entre o uso da linguagem e o campo em que se exerce essa atividade e, a partir do domínio desses gêneros, é que o locutor é capaz de submetê-los à seus objetivos específicos na construção enunciativa: "a norma, as formas prescritivas não funcionam mais só como referência à vinculação social, mas como meio de pensar, e, ao mesmo tempo, como coação para o pensamento" (FAÏTA, 1997, p. 171. Ênfase do autor).

Compreender os diferentes gêneros e poder submetê-los à intenções valorativas particulares, em situações cronotópicas específicas, permite novos processos de mutação, de hibridização de linguagens, o que pode contribuir para a evolução do próprio gênero (FAÏTA, 1997).

Os gêneros permeiam nosso pensamento e, conforme Machado (1997), modulam o contato entre a vida e o enunciado. Nessa perspectiva, os gêneros são essenciais às forças de dinamização da língua e constituem elementos fundamentais para a construção do enunciado. Como discute Bakhtin (1988), essas forças não se caracterizam enquanto entidades 
metafísicas independentes da realidade; pelo contrário, elas se constituem a partir do uso, a partir da organização social. O uso da língua, por seus falantes, geram forças contrárias que garantem as constantes mudanças e, simultaneamente, certa estabilidade na língua, que permite, nesse fluxo, que ela permaneça viva.

Denominadas, respectivamente, de forças centrífugas e forças centrípetas, estas não devem ser compreendidas como polos positivo ou negativo, visto que no interior de uma língua, ambas são responsáveis por garantir a "estática da vida da língua, mas também sua dinâmica” (BAKHTIN, 1988, p. 82). As forças centrífugas se classificam enquanto ininterruptos processos de descentralização e desunificação; em cada momento da vida da língua, a linguagem se diferencia não apenas em dialetos linguísticos (caracterizados pelas diferenças fonéticas), mas especialmente, em línguas socioideológicas relacionadas a contextos sociais (BAKHTIN, 1988). O autor denominou de plurilinguísmo a diversificação de linguagens existentes. Bakhtin (1988) ainda afirma que "a estratificação e o plurilinguismo ampliam-se e aprofundam-se na medida em que a língua está viva e [se] desenvolvendo” (p. 82) e essas transformações, responsáveis pela evolução da língua, se dão por conta do cruzamento entre línguas/linguagens.

Em contrapartida, as forças centrípetas atuam em meio ao plurilinguismo real encarnadas através da “língua comum” (BAKHTIN, 1988, p. 82). Esta não está dada indefinitivamente; pelo contrário, ela se estabelece em cada momento de sua vida linguística, em oposição ao discurso diversificado. É uma força que busca superar o plurilinguismo, opondo-lhe certas barreiras, “assegurando um certo maximum de compreensão mútua e centralizando-se na unidade real, embora relativa, da linguagem falada (habitual) e da literária ‘correta”” (p. 81). Dessa forma, uma língua, quando em contato com outras línguas, não se dissolve ou se transforma completamente; caso isso ocorresse seria impossível a comunicação entre seus usuários. As forças centrípetas garantem que o plurilinguismo seja “contido”, suficientemente, para que os falantes de uma língua possam ter um maximum de compreensão mútua em todas as esferas da vida ideológica.

Assim, enquanto a língua viva, concreta e fluída, constrói sentidos novos por meio dos diferentes cruzamentos de linguagens em suas respectivas esferas sociais, simultaneamente há o restabelecimento de sentidos únicos, já aceitos e estabilizados. Assim, cada "enunciação que participa de uma 'língua única’ (das forças centrípetas e das tendências) pertence também, ao mesmo tempo, ao plurilinguismo social e histórico (às forças centrífugas estratificadoras)” 
(BAKHTIN, 1988, p. 82). Toda enunciação se constitui, portanto, enquanto uma unidade contraditória e tensa de duas tendências opostas da vida verbal.

Pensar a relação entre o plurilinguísmo constitutivo da Libras e da língua portuguesa, a partir dessa perspectiva, traz novas possibilidades para se compreender as tensões e conflitos entre línguas em um mesmo espaço e tempo. Considerando as forças linguísticas, é possível afirmar a existência de influências recíprocas entre as línguas; entretanto, a posição hierárquica determinará em que grau a língua será transformada ou apenas se reafirmará em sua posição de prestígio. Tudo irá depender das relações históricas entre elas.

Esse processo de cruzamento de línguas e de hibridização foi descrito por Bakhtin (1988) como:

\begin{abstract}
A mistura de duas linguagens sociais no interior de um único enunciado, é o reencontro na arena deste enunciado de duas consciências linguísticas, separadas por uma época, por uma diferença social (ou por ambas) das línguas. (...) uma hibridização involuntária, inconsciente, é uma das modalidades mais importantes da existência histórica e das transformações das linguagens. Pode-se dizer que, no fundo, a linguagem e as línguas se transformam historicamente por meio da hibridização, da mistura das diversas linguagens que coexistem no seio de um mesmo dialeto, de uma mesma língua nacional, de uma mesma ramificação, de um mesmo grupo de ramificações ou de vários, tanto no passado histórico das línguas, como no seu passado paleontológico, e é sempre o enunciado que serve de cratera para a mistura (p. 156 -157).
\end{abstract}

Essas misturas linguísticas, assim como discutido anteriormente, são ideológicas e carregam consigo concepções de mundo e uma multiplicidade de vozes - polifonia - que mantém um contínuo diálogo. Como língua e cultura se encontram ligadas intrinsicamente, há uma mistura de línguas e, consequentemente, de culturas. O que resulta desse processo são novas construções linguísticas e culturais essenciais para a vida da língua. Entretanto, esses cruzamentos não são totalmente aceitos. Há resistências, por parte dos usuários e das instituições sociais, em manter a integridade da língua nativa. Criam-se, para tal, elementos que buscam unificar as linguagens.

As línguas de sinais foram ignoradas ou desconsideradas enquanto línguas durante séculos e, apesar das lutas das comunidades surdas, infelizmente, muitas vezes a Libras acaba por ser submetida a uma classificação de língua inferior ou até mesmo de “não língua”. Nessa relação histórica é possível afirmar que o português (a língua da maioria e dos historicamente “dominantes”) assume a posição de prestígio, de valor em relação a Libras (a língua da 
minoria e dos historicamente dominados) e, nas possíveis misturas entre línguas, a língua de sinais é quem acaba por sofrer fortes influências do português, e não o contrário. Isto ocorre nas diferentes esferas de atividade, historicamente ocupadas por ouvintes, em que há também a participação dos surdos, logo da Libras. Além disso, é importante ressaltar que os surdos só recentemente $^{7}$ começaram a participar ativamente de muitas das esferas de atividades que já se encontravam ocupadas por ouvintes, entre elas as referentes aos espaços políticos e escolares.

Assim, nos contatos entre estas línguas, é possível perceber o encontro das vozes que significam mundo e sujeito próprias da Libras e do português, uma intersecção que acontece no encontro entre indivíduos que compartilham um mesmo espaço (social) e tempo (histórico); um encontro entre línguas e culturas e, portanto, conflituosa e tensa. Os sentidos que virão a prevalecer nas esferas dependerão da "força" dos indivíduos envolvidos: dificilmente em um grupo de surdos prevalecerá formas ouvintes de interpretar o mundo; da mesma forma em um grupo com maioria ouvinte os sentidos próprios da Libras ficarão em segundo plano. Entretanto a situação se torna um pouco mais complexa quando pensamos nos ambientes escolares frequentados por surdos.

As escolas oralistas para surdos possuíam currículos e métodos de ensinos pensados por ouvintes que tinham a intenção de normalizar seus alunos e, apesar de serem compostas por uma maioria de sujeitos surdos (alunos), possuía todos os cargos administrativos e pedagógicos (professores, assistentes, coordenadores, diretores, etc.) ocupados por ouvintes. A ocupação de tais cargos hierárquicos garantia que os sentidos instaurados na escola partissem sempre do português, o que implicava em significações sobre o ser surdo e sobre a língua de sinais com base na "falta”, na deficiência. Os enunciados produzidos nesse ambiente, seja em português ou clandestinamente (escondido dos professores e autoridades escolares) em Libras, eram híbridos - não como uma mistura de linguagens próprias à língua de sinais, mas sim como uma mistura de línguas/culturas: o encontro de vozes e significações em ambas as línguas.

Felizmente, a escola não se restringia como o único espaço possível de trocas e de constituição dos alunos surdos, e fora dela era possível experimentar outros sentidos, outras possibilidades de ser no mundo em lugares de igualdade entre os indivíduos nos encontros de

\footnotetext{
${ }^{7}$ Ainda que a educação de surdos tenha tido seu início décadas atrás, esta era pensada a partir de concepções que compreendiam o surdo a partir da deficiência, buscando, através da oralização transforma-lo em um pseudoouvinte. Dessa forma, é possível afirmar que dificilmente, nesse período, os surdos poderiam participar ativamente nas esferas escolares.
} 
surdos. Nesse caso, a influência do português no interior dos grupos de surdos existia (pois os indivíduos compartilhavam histórias de oralização e opressão), mas insuficiente para instaurar sentidos baseados nessa língua.

Quando pensamos nessa relação no contexto da educação inclusiva proposta pelas políticas brasileiras atuais, podemos perceber que o simples convívio entre línguas não é a solução, e este compartilhar do espaço físico pode trazer implicação para os processos de constituição dos alunos surdos. Colocados em situações que apresentam a língua portuguesa como predominante e tendo, na maioria dos casos, o único contato com a língua por meio do tradutor e intérprete, os discursos com os quais os alunos surdos conviverão carregarão consigo sentidos próprios da língua portuguesa (mesmo materializados na Libras) e sobre o que é ser surdo em um mundo de ouvintes.

Em contrapartida, se pensarmos em um modelo de educação bilíngue que concebe os surdos a partir de sua diferença linguística, estar-se-á assumindo a Libras e sua importância na constituição dos sujeitos surdos. Esse modelo poderá, assim, se constituir em um espaço em que a língua de sinais predomine e, portanto, os discursos que ali circulam, enunciados a partir da posição sociocultural daquele que enuncia em Libras. Nesse sentido, a escola enquanto esfera de atividade humana estará produzindo enunciados relativamente estáveis constituindo diferentes gêneros discursivos; entretanto, diferente do que foi citado nos exemplos anteriores, as vozes e os sentidos em língua portuguesa, ainda que se encontrem misturados no interior dos enunciados, desde que haja a presença de professores surdos, terão, potencialmente, uma menor força e uma menor influência na constituição dos gênero,.

É importante ressaltar que, embora as construções híbridas sejam essenciais para a evolução da Libras, é imperativo garantir espaços em que a Libras e a língua portuguesa não sejam postas em uma relação hierárquica, mas que venham a ser consideradas com status linguísticos igualitário. A garantia desses espaços é essencial, visto que as construções híbridas refletem direta ou indiretamente na constituição dos gêneros discursivos na esfera escolar (e na forma como os docentes, junto aos alunos, utilizarão os gêneros na relação cotidiana). Os gêneros estarão presentes em todas as relações estabelecidas no interior da escola, além de exercerem um importante papel no processo de reflexão da primeira língua, pois é a partir do domínio de diferentes gêneros que o sujeito conseguirá submetê-los à sua individualidade. Este também deveria ser o ponto de partida para o ensino, de forma que o aluno seja capaz de posicionar-se e expressar-se no mundo, sendo capaz de se relacionar com os discursos alheios e, por meio de uma atitude responsiva ativa, fazer ecoar sua própria voz. 
Para que isso seja possível, entretanto, é preciso ter claro a forma pela qual esses gêneros nos são dados. Como ressaltado anteriormente, a partir do momento em que nascemos já estamos inseridos em um mundo permeado de linguagem e, consequentemente, por gêneros discursivos. Isso implica, portanto, que assimilamos esses gêneros da mesma forma como o fazemos com nossa primeira língua: na vivência. Por meio de enunciados concretos (de outrem) que ouvimos, vemos e reproduzimos nas relações com o outro.

Dessa forma, nos posicionamos contra as práticas atuais de ensino de gêneros nas escolas que, ao tentarem torná-los mais didáticos para seus alunos, os resumem a "gêneros textuais" (ensino de como se escreve/estrutura uma carta, um bilhete, entre outros) retirandoos de seus contextos concretos e reduzindo-os, unicamente, a suas formas composicionais e estilo. Nesse processo, é possível que o objetivo histórico social dos gêneros se perca. Muitas vezes, em busca de metodologias que permitam um acesso mecânico mais "rápido", as práticas educacionais de "ensino" da primeira língua esquecem que o uso de determinados gêneros está sempre vinculado a uma esfera específica de atividade humana, ainda que sejam utilizadas de formas diversas e por sujeitos com valores apreciativos distintos. Ensinam-se regras de como organizar gramaticalmente orações, sem explicar os "porquês", as intenções das escolhas realizadas a partir do projeto discursivo daquele que utiliza o gênero.

Não estamos aqui defendendo que se pare de ensinar as formas prescritivas da língua, em especial a gramática, nas escolas; entretanto estas deveriam ser consideradas nas condições concretas de uso, considerando-se as intenções do autor ao se utilizar desta ou daquela forma linguística. Fiorin (2014) ao discutir o ensino de português como primeira língua, levanta questões muito próximas ao exposto aqui. Para o autor,

no ensino de língua materna, o aluno deveria ser levado a compreender a natureza e a função da linguagem humana: as línguas variam, as línguas mudam, o uso de determinadas variedades linguísticas são marcas de uma identidade social, a linguagem é uma forma de agir no mundo e assim por diante (p. 37).

O uso linguístico, para o autor, possui uma dimensão social que implica no uso de variedades em função do gênero utilizado para um determinado contexto. Assim, o ensino do “jeito certo de falar” é tão importante quanto as variedades linguísticas são no processo de reflexão. Entretanto, o que é possível perceber atualmente é que há uma limitação de pouquíssimos gêneros previstos nos currículos escolares, escolhidos como formas de escrita de valor, valor este que ignora a diversidade e a pluralidade de linguagens e formas de utilizá- 
las. Isso, entretanto, não significa dizer que alunos e professores não vivam uma multiplicidade de gêneros (não previstos no currículo) em suas relações cotidianas e nos processos de aprendizagem, mas sim que poucos deles ganham espaço nos momentos de reflexão da língua.

Para que haja a garantia do uso e reflexão das multiplicidades de linguagens existentes, ao mesmo tempo em que se tenta auxiliar os profissionais que trabalham nas diferentes áreas do conhecimento, foram elaborados os Parâmetros Curriculares Nacionais PCNs (BRASIL, 1997). Destaca-se, neste estudo, o referente ao ensino de língua portuguesa nos anos iniciais do ensino fundamental, que embora tenha sido construído para a educação de ouvintes, por voltar-se ao ensino de primeira língua, pode auxiliar na reflexão da educação de surdos desde que seja feito um deslocamento para a Libras como primeira língua.

Rojo $(2000)^{8}$, ao analisar este documento, o descreve como fontes de referências nacionais para as práticas educativas, tendo como principal objetivo fomentar reflexões sobre os currículos propostos nos diferentes níveis educacionais. Ainda de acordo com a autora, este documento deveria servir como base de reflexão para que cada escola elabore seu próprio currículo, de acordo com sua realidade, ao mesmo tempo em que garanta o acesso ao básico estipulado nos documentos. Dessa forma, acredita-se ser possível a transposição dos PCNs de língua portuguesa para o ensino e reflexão da primeira língua dos surdos considerando sua realidade educacional particular e as especificidades da Libras.

Inicialmente, neste documento, são apresentados os objetivos gerais para auxiliar o professor na execução de seu trabalho, de forma a possibilitar "que as crianças dominem os conhecimentos de que necessitam para crescerem como cidadãos plenamente reconhecidos e conscientes de seu papel em nossa sociedade” (BRASIL, 1997, “Ao Professor”). O texto não expõe métodos obrigatórios, mas apresenta parâmetros para auxiliar os docentes e as instituições a refletirem sobre sua prática. Na apresentação do documento, observa-se a importância da língua portuguesa, em suas modalidades oral e escrita, para a efetiva participação social do sujeito na sociedade, como forma de levá-lo a se posicionar e a expressar seus pontos de vista. Ao longo do documento é possível perceber a compreensão de

\footnotetext{
${ }^{8}$ A autora, em seu texto, se refere ao documento "Parâmetros Curriculares Nacionais - Língua Portuguesa. Terceiro e Quarto ciclos do ensino fundamental” de 1998. Entretanto, o PCNs de 1997 possui uma estruturação e uma base teórica bastante semelhante ao de 1998, além de ter um grupo de elaboração com muitos membros em comum. Por este motivo, foi realizada uma aproximação das discussões realizadas pela autora sobre o documento de 1998 em relação ao de 1997.
} 
que a língua perpassa todas as esferas e relações da vida dos sujeitos, assim como sua importância para a interação com o outro.

Observa-se ainda, no decorrer do texto, um embasamento teórico que leva em consideração alguns conceitos que tem, como base, as concepções de Bakhtin: o de discurso, entendido como o uso da língua em seu contexto concreto, e o de gêneros do discurso. Essa perspectiva teórica permite, portanto, a aproximação aqui realizada para se pensar no trabalho com a Libras, por pressupor e enfatizar a interação verbal, sem limitá-la a oralidade ou a escrita.

No tópico "Linguagem, atividade discursiva e textualidade", algumas concepções referentes ao que é língua tornam-se claras, embora seja possível perceber o diálogo com diferentes posicionamentos teóricos ao longo do texto. Entre eles, está o conceito de gêneros do discurso como concebido por Bakhtin: "Todo texto se organiza dentro de um determinado gênero. Os vários gêneros existentes, por sua vez, constituem formas relativamente estáveis de enunciados, disponíveis na cultura" (BRASIL, 1997, p. 23). Essa mesma concepção de gêneros torna a aparecer nos tópicos "Que fala cabe à escola ensinar" e "Que escrita cabe à escola ensinar".

No primeiro, voltado ao uso da linguagem oral, há uma séria questão a respeito do preconceito referente ao falar "certo" e ao falar "errado", relacionando esta discussão ao saber utilizar a língua considerando as características específicas do contexto. Apesar de não nomear essa compreensão como gêneros, é possível esta aproximação, na medida em que, para Bakhtin (2011), todos os nossos enunciados são modulados por gêneros discursivos, mesmo que não tenhamos consciência de seu uso. Saber falar em determinados contextos implica, portanto, em dominar seus respectivos gêneros. Dessa forma, há a necessidade dos alunos assimilarem esses gêneros na relação com usuários da língua.

No segundo tópico, relacionado ao ensino da escrita, a questão do gênero do discurso torna a aparecer, porém, dessa vez, reduzindo-o ao conceito de textos escritos: "Todo texto ${ }^{9}$ pertence a um determinado gênero, com uma forma própria, que se pode aprender" (BRASIL, 1997, p. 28). Aprender esses gêneros também implica em saber utilizá-los em contextos concretos e, nesse sentido, enfatizam-se práticas voltadas à identificação e produção de textos a partir de determinados gêneros.

\footnotetext{
${ }^{9} \mathrm{O}$ conceito de "texto" utilizado no documento refere-se à escrita, distanciando-se daquele utilizado por Bakhtin (2011), no qual texto se aproxima do conceito de discurso, o que permite sua materialização em textos orais, escritos, vídeos, etc.
} 
Em ambos os tópicos, pressupõe-se, portanto, que é a partir do domínio dos gêneros que o aluno é capaz de utilizar a língua em diferentes contextos e de submetê-la aos sentidos pretendidos em relação ao seu projeto enunciativo.

Dos conteúdos previstos para o primeiro ciclo (anos iniciais do ensino fundamental) é possível encontrar a possibilidade de trabalhos com diferentes gêneros, divididos entre:

\section{Gêneros adequados para o trabalho com a linguagem oral:}

- contos (de fadas, de assombração, etc.), mitos e lendas populares;

- poemas, canções, quadrinhas, parlendas, adivinhas, trava-línguas, piadas;

- saudações, instruções, relatos;

- entrevistas, notícias, anúncios (via rádio e televisão);

- seminários, palestras.

Gêneros adequados para o trabalho com a linguagem escrita:

- receitas, instruções de uso, listas;

- textos impressos em embalagens, rótulos, calendários;

- cartas, bilhetes, postais, cartões (de aniversário, de Natal, etc.), convites, diários (pessoais, da classe, de viagem, etc.);

- quadrinhos, textos de jornais, revistas e suplementos infantis: títulos, lides, notícias, classificados, etc.;

- anúncios, slogans, cartazes, folhetos;

- parlendas, canções, poemas, quadrinhas, adivinhas, trava-línguas, piadas;

- contos (de fadas, de assombração, etc.), mitos e lendas populares, folhetos de cordel, fábulas;

- textos teatrais;

- relatos históricos, textos de enciclopédia, verbetes de dicionário, textos expositivos de diferentes fontes (fascículos, revistas, livros de consulta, didáticos, etc.) (BRASIL, 1997, p. 72-73. Ênfase adicionada).

Brait (2000), ao analisar o documento de PCNs de 1998 (referente aos anos finais do ensino fundamental $)^{10}$, discutiu que os conceitos de gêneros do discurso e tipologias textuais ${ }^{11}$ foram utilizados sem uma devida diferenciação, uma mistura do conceito de gêneros de Bakhtin (que será discutida mais profundamente adiante) com uma forma de organização interna do texto a partir de sequências discursivas pré-estabelecidas. Sobral (2009), em seu artigo, aponta que os tipos textuais não se encontram diretamente ligados as esferas de atividades humanas, ao contrário dos gêneros do discurso que os organizam, e destaca a existência de apenas quatro grandes tipos de textos: descritivo, narrativo, dissertativo e institutivo, que podem ser combinados de diferentes maneiras. O autor compreende as formas textuais como o "plano material de realização dos discursos e gêneros, não como uma

\footnotetext{
${ }^{10}$ Assim como no caso de Rojo (2000), o mesmo se aplica a Brait (2000).

11 A palavra texto quando utilizada no sentido de tipologia textual terá um significado diferente do explicitado anteriormente, quando empregado à luz da teoria bakhtiniana, referindo-se apenas a sua materialidade de textos escritos.
} 
possível 'essência’ do gênero” (p. 4, ênfase do autor), dessa forma, o que mobiliza os tipos textuais são estratégias discursivas, formas de realização do projeto discursivo do interlocutor.

A não clareza sobre o sentido de texto presente no documento faz parecer que gêneros do discurso e tipologias textuais dizem respeito à mesma coisa. Por este motivo, ressaltamos que, no contexto dessa pesquisa, consideraremos apenas os gêneros que reconhecemos enquanto tal à luz da concepção de Bakhtin. Assim, discordamos da divisão realizada nos PCNs de língua portuguesa entre gêneros orais e escritos visto que, em muitos exemplos citados no documento, nos deparamos com gêneros que podem se constituir tanto na oralidade quanto na escrita, como os contos, poemas, canções, piadas, instruções, entrevistas, notícias, anúncios, instruções de uso e parlendas.

No entanto, apesar de não apresentar uma clareza sobre as concepções que utiliza, é possível perceber que os PCNs apresentam uma grande preocupação relacionada ao fato do aluno ser capaz de se posicionar e expressar suas opiniões em diferentes esferas da vida. Nesse sentido, a escola torna-se um local privilegiado para tal prática, visto que cada aluno que a frequenta vive em um contexto específico e possui distintas experiências e, portanto, relaciona-se com diferentes esferas e gêneros. Entretanto, ao elaborar um currículo (ou um documento que oriente currículos, como é o caso dos PCNs) a escola procura diminuir essas diferenças ao tentar garantir que todos os alunos conheçam e construam conhecimentos e gêneros, produzidos historicamente pela humanidade, do mesmo modo. Por este motivo, o documento propõe práticas com gêneros discursivos nos processos de reflexão da primeira língua.

É, portanto, considerando o reconhecimento que os PCNs realizam a respeito da importância da apropriação dos gêneros discursivos para se posicionar no mundo, assim como o papel da escola como espaço que garanta sua vivência, junto às discussões realizadas nesse capítulo sobre o conceito de gêneros do discurso, que propomos a transposição dessa proposta também para o ensino bilíngue para surdos, contanto que as especificidades da Libras sejam respeitadas.

Para a transposição dessa proposta é preciso compreender como os gêneros discursivos são constituídos. Para tal, retomaremos as discussões realizadas por Bakhtin (2011), o autor realiza a diferenciação entre gêneros primários e gêneros secundários. Os gêneros primários se constituem a partir das circunstâncias de comunicação verbal cotidiana, nas diferentes esferas de atividade humana, no encontro e interação entre sujeitos que elaboram enunciados relativamente estáveis próprios de cada esfera. São as várias formas de 
dizer relacionadas, necessariamente, com o tempo e o espaço em que me encontro, juntamente com a quem direciono meu enunciado. Visto que a Libras é utilizada por um grupo social em sua vida cotidiana em diferentes contextos, é possível afirmar que existem enunciados relativamente estáveis vinculados a estas esferas de atividade, ou seja, que existem gêneros discursivos primários. Esses gêneros se constituem, assim, como recortes ideológicos de mundo, intrinsecamente vinculados às esferas de sua criação.

Os gêneros secundários, entretanto, possuem uma formação diferente. Eles são característicos de circunstâncias de uma comunicação cultural mais complexa e relativamente mais evoluída; em especial, mas não unicamente, nas formas escritas. Ao serem constituídos, os secundários incorporam e absorvem os gêneros primários, que "perdem sua relação imediata com a realidade e com os demais discursos” (BAKHTIN, 2015, p. 263), e são submetidos a unidade dos secundários, conservando sua forma e seu significado cotidiano apenas em seu conteúdo. Em Questões de Literatura e de Estética, Bakhtin (1988), ao estudar a constituição do discurso romanesco (gênero secundário), exemplifica essa incorporação e absorção dos gêneros primários:

Essas unidades estilísticas heterogêneas, ao penetrarem no romance, unemse a ele num sistema literário harmonioso, submetendo-se à unidade estilística superior do conjunto, conjunto este que não pode ser identificado com nenhuma das unidades subordinadas a ele (p. 74).

Dessa forma, o desenvolvimento dos gêneros secundários não pode ignorar a existência dos gêneros primários, vinculados ao cotidiano.

Cabe, portanto, neste momento, problematizar a formação desses gêneros secundários em Libras. A existência de gêneros primários garante a possibilidade de os secundários sejam estabelecidos. Entretanto, em consonância com Lodi (2014b), questionamos como está se constituindo alguns gêneros secundários nas esferas educacionais (em especial, dos gêneros previstos nos documentos oficiais) em Libras, considerando a relação histórica entre a língua de sinais e o português nesses espaços.

Lodi (2014b) indica a possibilidade de haver influência da língua portuguesa na elaboração de alguns gêneros do discurso secundários em Libras, considerando que essas línguas compartilham das mesmas esferas de atividade, no mesmo espaço/tempo. Essas implicações levam em conta a relação de valores nada harmoniosas e assimétricas entre as línguas nos diferentes espaços que compartilham. Esse diálogo assimétrico entre os contextos 
socioculturais compartilhados entre a Libras e a língua portuguesa permite inferir que há, na constituição dos gêneros secundários em Libras, uma possível hibridização (inevitável no convívio entre línguas) entre a Libras e a língua portuguesa (LODI, 2014b), uma mistura de vozes e significações de mundo (particulares de cada língua) que podem se contradizer, conviver ou sobrepujar umas às outras, em especial porque os gêneros em Libras, que se encontram relativamente estabilizados ou que ainda estão em formação, compartilham o mesmo espaço e tempo que o português.

Assim, considerando o que está previsto nos PCNs de língua portuguesa e a importância dos gêneros discursivos nos processos de reflexão da primeira língua, optou-se por investigar e analisar como estão sendo constituídas as fábulas ${ }^{12}$ em Libras na esfera virtual - principal loci de comunicação dos surdos e uma esfera privilegiada para a perpetuação de discursos nessa língua.

\section{III.2.1 Fábulas: transformações de um gênero na história}

Como discutido na seção anterior, gêneros do discurso são enunciados relativamente estáveis e, portanto, considerados unidades culturais essencialmente abertas sempre vinculadas às esferas de atividades humanas. Por este motivo, os gêneros sempre estão suscetíveis a transformações que acompanharão as mudanças discursivas, ideológicas e sociais das esferas nos quais são enunciados. Assim, essa seção tem como objetivo investigar as principais alterações e características do gênero fábula e das esferas nas quais ele se vinculou no decorrer da história.

A fábula é um dos poucos gêneros que, segundo Rodriguéz Adrados (1979), representa uma continuidade ao longo dos séculos: há registro de gêneros semelhantes em diferentes regiões do mundo (a Suméria e a Índia são alguns dos exemplos citados pelo autor), entretanto, as mais conhecidas e difundidas no Brasil possuem origem greco-latina (Grécia e Roma, a partir do século VI a.C.). Nesse período histórico de mais de dois mil anos, a fábula sobreviveu, passou de língua para língua e sofreu transformações, derivações e recriações, considerando-se o espaço e o tempo em que eram/são enunciadas. Rodriguéz Adrados (1979) afirma que essa sobrevivência apenas foi possível devido ao fato das fábulas serem um gênero essencialmente abertos (p. 11), isto é, apesar do surgimento de infinitas variações, em sua essência, a fábula continua possibilitando a crítica vinculada à sabedoria popular, fato que permite sua constância. Dessa forma, como será possível perceber adiante, apesar de ter sido

\footnotetext{
${ }^{12}$ A justificativa para a escolha deste gênero se dará na seção seguinte.
} 
enunciada em contextos históricos e sociais extremamente distintos e por sujeitos com objetivos discursivos diferentees, a fábula permaneceu vinculada à sabedoria popular, ainda que sua forma composicional e seu estilo tenham sido alterados para melhor expressar o posicionamento de seus enunciadores.

Este aspecto camaleônico, apontado por Rodriguéz Adrados (1979), se da pela falta de autores marcantes na história da fábula, assim como a falta de textos em “estados originais”, em um período em que as únicas cópias possíveis eram realizadas por copistas ou tradutores que possuíam liberdade para inserirem suas interpretações ou ideias nas obras. Desse modo, não é possível afirmar uma única constituição desse gênero: em sua origem ele se manifestou por meio da prosa, mas também há registros de fábulas na forma de versos, tanto na oralidade quanto na escrita. Destacamos, entretanto, a importância da escrita para difusão, tradução e perpetuação do gênero além de suas futuras transformações e variações no que diz respeito ao seu uso.

Apesar da existência desse gênero em diferentes países, atualmente, no Brasil, as fábulas mais conhecidas possuem origem greco-latina, em especial àquelas escritas por Esopo e Fedro, datadas a partir do século VI a.C. Gómez (2014) afirma que, nos contextos grecolatinos, a fábula nasceu para se fazer ouvir a voz dos fracos em oposição aos poderosos, com fortes elementos políticos e sociais, vinculados a crítica e a sátira de uma sociedade com morais próprias de suas épocas e culturas.

Esopo era um escravo que viveu na Grécia antiga, no século VI a.C.; ele era uma espécie de orador popular "que inseria, em seus discursos, histórias inventadas ou reais como meio atraente e eficaz de persuasão” (PORTELLA, 1983, p. 120). Gómez (2014) afirma que Esopo ficou conhecido como um fabulista por excelência e um modelo a ser seguido, por ser responsável por compilar a primeira coleção de fábulas (“La vida de Esopo”, p. 1 apud GOMES, 2014), obra que se difundiu na Europa tardiamente; a ele também é atribuída a forma como se estrutura o gênero, cujas principais características mantiveram-se tal qual as conhecemos hoje. A autora ainda afirmou que Esopo compôs suas fábulas para confrontar aqueles que zombavam dele, compartilhando ensinamentos morais provindos de sua experiência própria ou da sabedoria popular com seus companheiros.

Esopo contou suas fábulas tanto por meio da oralidade quanto pela escrita. Na oralidade a relação autor/interlocutor acontecia face a face, aquele que narrava tinha o papel de levar seus ouvintes à uma reflexão a respeito de suas próprias vidas, ocupando uma posição de mestre ou professor perante seus interlocutores. Esses momentos de ensinamento 
ocorriam na esfera do cotidiano, nos quais Esopo incorporava as fábulas em seu discurso para persuadir seus iguais, e, apesar de trazerem um caráter pedagógico, não se encontravam, exclusivamente, em situações próprias para tal. No caso da escrita, a relação autor/interlocutor era mediada pelo texto, não necessariamente permitindo uma interação entre os sujeitos pósleitura. Entretanto, a posição que o autor ocupava não era muito diferente, visto que ele permanecia como “detentor” do conhecimento levando o leitor à reflexão. Esses textos, entretanto, não eram acessíveis a todos, pois apenas uma pequena parte da população era letrada; desse modo, sua leitura restringia-se a pessoas que ocupavam grandes cargos na sociedade e em espaços de formação, entre filósofos e sábios da época.

Fedro, por sua vez, era um "ex-escravo, perseguido e oprimido pela sanha dos poderosos políticos de sua época” (PORTELLA, 1983, p. 127), e a ele é atribuída a responsabilidade pela introdução das fábulas esópicas em Roma, durante o século I d. C. Essa introdução pode ser descrita mais como uma adaptação do que como uma tradução, visto que as fábulas de Fedro possuem um teor diferente das de Esopo, em especial por sua intenção discursiva. Segundo Gómez (2014), isso ocorreu porque, diferentemente de Esopo, que buscava confrontar aqueles que eram mais fortes e prevenir seus iguais de um sofrimento por ele já vivido, Fedro estava mais interessado em denunciar os "vícios” da sociedade em que vivia. A fábula permitiu que o ex-escravo denunciasse as injustiças de seu tempo de forma mascarada, na medida em que precisava tomar cuidado com seus perseguidores e inimigos políticos.

Diferente de Esopo (o orador popular), a escrita de Fedro não apenas buscava que seus iguais refletissem sobre a opressão que sofriam, mas era dedicada, implicitamente, aos seus opressores. Ao contrário de seu antecessor, Fedro não se encontrava na esfera do cotidiano, mas sim em um contexto muito mais político; seu objetivo não era o confronto com aqueles que zombavam dele, mas sim contra toda sua sociedade.

No caso desses dois autores, o principal foco das fábulas era, de acordo com Portella (1983), a moral e, para que esta pudesse chegar ao interlocutor sem desvios, seus textos eram curtos e densos, sacrificando, por vezes, a ação, o drama, a vivacidade de suas narrativas, para que, dessa forma, pudessem levar o leitor ao alvo pretendido: o ensinamento moral (Esopo) e a crítica (Fedro).

A fábula, entretanto, não permaneceu desvinculada de outras esferas. Durante o período Helenístico (entre 323 a.C. e 146 a.C.), Goméz (2014) destacou sua inclusão entre filósofos, sábios e igrejas (as principais figuras responsáveis pela formação escolar da época) 
como um exercício retórico, a progymnasmata (p. 3), que visava o aprimoramento da escrita e da memória.

Goméz (2005) explicou que a progymnasmática podia realizar-se de três maneiras: escrevendo, lendo ou falando. Em especial, os exercícios de escrita podiam influenciar o desenvolvimento do vocabulário ou de composição e redação de textos. Em relação ao segundo elemento, o autor expôs que os exercícios visando seu desenvolvimento podiam ser realizados de três formas: por intermédio da tradução, do parafraseamento dos modelos literários, ou de um tratamento diferenciado a um mesmo texto. É neste último que se encontra, de acordo com o autor, o coração da progymnasmática.

Esse tratamento diferenciado a um mesmo texto se relaciona, de acordo com Goméz (2005), com o proposto por Aftonio $^{13}$ : uma prática que permitiria ao orador, independentemente de seu ofício ou de seu objetivo enunciativo, adquirir um conjunto de métodos, que possibilitaria ao falante, por meio do uso e da experiência, uma base necessária para produzir a convicção, a aprovação ou a desaprovação, de convencer com base na inteligência, mas também de saber seduzir seu interlocutor com a imaginação. Para tal, era necessário que a pessoa que praticava este exercício fosse capaz de assimilar um texto e transformá-lo de diferentes formas.

Posteriormente a esse período, com o início da Idade Média (entre os séculos V e XV), a fábula deixou de ser prioridade nos exercícios retóricos para dar espaço à outros gêneros, em especial aqueles com forte teor moralizante e religioso (por exemplo, a anedota e a parábola) ${ }^{14}$. Isso ocorreu devido à forte influência que a Igreja exercia, por ser o único órgão com autoridade para realizar a mediação entre a palavra de Deus e seus seguidores. Por deter o acesso que a população poderia ter sobre os textos sagrados e outras escritas, o clero acabou por ficar responsável, durante muitos séculos, pelo ensino da leitura e da escrita, assim como pela difusão de textos (por meio dos monges copistas). Por ser um gênero utilizado na educação das classes sociais mais elevadas, mas por também ser utilizada por instituições religiosas para que o povo mais “simples” pudesse entender os ensinamentos divinos, a fábula acabou por ser incorporada às inúmeras coleções que reuniam diferentes tipos de gênero em um mesmo livro com objetivos pedagógicos/doutrinadores/religiosos.

\footnotetext{
${ }^{13}$ Diretor de uma instituição de ensino que deixou uma coleção de 40 fábulas com intenções claramente didáticas.

${ }^{14}$ Portella (1983), em seu texto, levanta semelhanças e diferenças entre estes gêneros e a fábula tal qual a conhecemos na atualidade. Importante ressaltar que todos são gêneros que permitem um ensinamento, além de, em alguns casos, fazer-se uso de alegorias no corpo da narrativa.
} 
Apesar da maior presença de outros gêneros, Goméz (2015) destacou que as fábulas esópicas ${ }^{15}$ prevaleceram, entretanto com um teor bastante distinto ao de sua origem. Apesar de conservarem a função pedagógica, o caráter político (o de ensinar pessoas a lutar, em situações semelhantes ao que autor vivia) cedeu seu lugar a uma intenção moralizante. Entretanto, a autora citou variações de fábulas esópicas usadas com intenções de desvelar os problemas da sociedade da época, como é o caso de Roman de Renart ${ }^{16}$, considerado um retrato satírico do sistema feudal e de suas principais características. Essa mesma fábula incorporou também outros sentidos e foi utilizada por diferentes autores ao longo da Idade Média.

No Renascimento (século XVI), de acordo com Goméz (2015), as fábulas desviaramse das intenções didáticas e religiosas e seu uso, novamente, relacionou-se ao exercício retórico. Foi apenas com La Fontaine que as fábulas, mais semelhantes ao seu formato grecolatino, tornaram a aparecer na Europa.

La Fontaine viveu em Paris, durante o século XVII (1621-1695). Filho de nobres, La Fontaine contou grande parte de suas fábulas nos luxuosos salões de Luís XIV, com a função de entreter os cortesões e nobres do local. Como o autor se relacionava com pessoas letradas e com mais acesso a estudos, a contação e/ou escrita das fábulas tinham a narrativa como elemento dominante, pois ele acreditava que apenas por meio de uma narrativa longa e bem enfeitada, ele poderia atingir seus objetivos (PORTELLA, 1983). Dessa forma, La Fontaine também deixou sua marca na constituição das fábulas.

Portella (1983) exemplificou e diferenciou as características discursivas dos três autores por meio da análise da moral ${ }^{17}$ da fábula “O Parto da Montanha”: “É melhor prometer menos e fazer mais”. Em sua análise, o autor buscou reconhecer as diferenças nas escolhas enunciativas realizadas por Fedro e La Fontaine, expondo que elas estão relacionadas, principalmente, com o contexto em que os sujeitos viviam. Apesar de utilizarem o mesmo gênero e a mesma moral, Portella (1983) identificou formas muito específicas de enunciar esta fábula, marcadas por diferenças linguísticas, culturais, de espaço e de tempo, além das diferentes intenções discursivas de cada autor.

\footnotetext{
${ }^{15}$ Goméz (2015) tem como objetivo em seu artigo discutir as transformações das fábulas esópicas desde o período gregolatino (com o surgimento das fábulas de Fedro) até o século XV (fim da Idade Média).

${ }^{16}$ A fábula em questão é baseada na “A partilha do Leão”, escrita por Esopo. Nessa história, um leão, um chacal, uma raposa e um lobo fazem um acordo: caçariam juntos e em seguida partilhariam o que conseguissem encontrar. O leão se autoproclama líder do grupo e se torna responsável pela partilha, entretanto, o mesmo decide que, por ser o rei da selva, deveria ficar com todas as partes.

${ }^{17}$ Compreendida pelo autor como uma verdade geral, ou a alma da fábula, ao qual o interlocutor deve ser levado
} 
Com base em suas análises sobre as diferentes formas de enunciar as fábulas e utilizando como base os textos de Esopo, Fedro e La Fontaine, Portella (1983) assim estabeleceu as características das fábulas greco-latinas:

Como forma literária específica, a fábula é uma narração breve, em prosa ou em verso, cujos personagens são, via de regra, animais e, sob uma ação alegórica, encerra uma instrução, um princípio geral ético, político ou literário, que se depreende naturalmente do caso narrado. (p. 121)

Considerando que atualmente no Brasil as fábulas mais conhecidas utilizam como base os textos de Esopo e as recriações realizadas por La Fointaine, utilizaremos a definição acima para discutirmos, mais adiante, como se constitui o gênero do discurso fábula, a partir das esferas em que elas foram enunciadas, ou seja, seu tema, forma composicional e estilo.

Após a aparição de La Fontaine, as fábulas tornaram a ser popular, voltaram a ser foco da literatura europeia e também dos exercícios de leitura, escrita e educação. O resgate à sua origem permitiu o ressurgimento do exercício retórico utilizado durante o período Helenístico: a progymnasmata ou “exercícios preparatórios” (Goméz, 2005, p. 35). De acordo com o autor, essa prática se tornou responsável pela inserção definitiva da fábula como um recurso de aprendizagem escolar, inclusive na atualidade.

Esse exercício foi principalmente dirigido às crianças e adolescentes, prática que se popularizou principalmente entre os pedagogos e gramáticos que lidavam com as primeiras experiências dos alunos ${ }^{18}$ com a literatura. Para tanto, a fábula se caracterizava como um gênero privilegiado, visto que, em sua maioria, se constituam enquanto textos curtos e densos e carregavam uma moral que se encaixava aos objetivos pedagógicos. Goméz (2005) destacou a memorização e repetição de fábulas esópicas, principalmente com crianças que estavam ingressando na escola, visto que os textos de Esopo se constituiriam como uma referência moralizadora.

A respeito das práticas escolares envolvendo a fábula, Pereira (2005) discutiu que ela foi utilizada como um instrumento pedagógico que permitia à criança adquirir elementos próprios da língua (como reflexões linguísticas), mas também as levava ao conhecimento dos valores históricos humanos. É possível reconhecer a memorização e a repetição como práticas que se perpetuaram e que se encontram presentes até os dias atuais, ainda que não mais vinculadas unicamente à fábula. Concordamos com Pereira (2005) que, no caso deste gênero

\footnotetext{
${ }^{18}$ Importante ressaltar que a educação e a aprendizagem das letras ainda eram restritas a uma pequena parte da população: à nobreza e ao clero.
} 
específico, sua sobrevivência até atualidade tenha se dado em especial na esfera escolar. Acreditamos, entretanto, na possibilidade de trabalhos que vão além da repetição e que permitam uma reflexão mais aprofundada da fábula: de sua forma e de seu ensinamento (não enquanto uma verdade a ser obedecida, mas sim como um questionamento, uma reflexão dos sentidos por trás dessa moral).

No Brasil, as fábulas utilizadas são, quase que exclusivamente, textos de autoria ou adaptações de Esopo ou de La Fontaine, muitas vezes sem a devida diferenciação entre os autores; seu uso implica ainda no ensino da "forma" milenar desse gênero que, nos livros didáticos, apresenta-se engessada e presa na história. No caso brasileiro, as fábulas foram traduzidas de suas línguas de origem para o português, mas não permaneceram inalteradas. Em seu uso, esse gênero sofreu alterações no interior de nossa cultura, ganhando novos sentidos e até novas formas de serem contadas. Algumas ganharam mais espaço, como é o caso de A Cigarra e a Formiga, A Raposa e o Lobo e A Lebre e a Tartaruga, conforme discutiu Pereira (2005); outras, apesar de conhecidas, raramente são lembradas por alunos ou adultos. É preciso considerar que as fábulas em Libras estão, muito provavelmente, sendo traduzidas do português e, por este motivo, pode, ou não, acompanhar as mudanças que esse gênero sofreu.

\section{III.2.2 A escolha do gênero: aspectos da fábula}

Compreender o contexto histórico da fábula nos ajuda a enxergar os determinados contextos e situações que permitiram o surgimento e transformações desse gênero. Inicialmente, é possível afirmar que a fábula se constituía um gênero do cotidiano, em específico em situações de ensinamento dos mais velhos ou mais sábios aos mais novos, com um intuito pedagógico não formal. Apesar de já possuir uma forma escrita, foi apenas posteriormente, com sua popularização, que esse gênero foi se aproximando de uma esfera mais formalizada, como é o caso de La Fontaine e a utilização desse gênero por estudiosos.

Em relação à sua temática, à fábula sempre esteve intrinsicamente relacionada à uma sabedoria popular; é, portanto, com base na moral, na "alma" ou "verdade geral" (PORTELLA, 1983, p. 121) que a narrativa - ou seja, a forma composicional e o estilo - foi pensada. Como é o caso da verdade "É melhor prometer menos e fazer mais” e as narrativas de Esopo, Fedro e La Fontaine, apresentados anteriormente neste tópico.

Para alcançar o seu objetivo social e ideológico (transmitir o ensinamento, defender-se dos mais fortes, criticar a sociedade em que vive) a fábula possui uma forma composicional 
bastante específica. Comumente possui uma narrativa densa e curta (podendo variar a depender da intenção discursiva daquele que enuncia): como o foco deve ser o ensinamento ou a crítica, o estilo da narrativa deve ser criada e pensada em sua função; por este motivo, a fábula dispensa muitos detalhes ou grandes quantidades de personagens ${ }^{19}$. A narrativa deve partir de um único ponto de desequilíbrio/conflito, que deve ser desenvolvido sem muitas delongas, para que o foco do ouvinte se mantenha na moral.

Outro aspecto da forma composicional da fábula está justamente relacionado à narrativa de uma ação alegórica que oculta um ensinamento. Portella (1983) justifica que a verdade relacionada ao ensinamento precisa sempre estar camuflada por trás de uma alegoria; dessa forma, aquele que ouve a fábula não se sentirá diretamente atingido por ela, ainda que consiga identificar-se com as situações (as qualidades ou defeitos dos personagens) presentes no texto. Essa ação alegórica se dá, majoritariamente (mas não obrigatoriamente, visto a utilização de personagens oriundos da natureza viva, da natureza morta, homens, divindades e até de seres imaginários) por meio da presença de animais como protagonistas das narrativas. O tipo de personagem pouco importa à fábula, contanto que essa escolha respeite dois principais motivos apontados por Portella (1983): a sensação de “maravilhoso” ou de “encantamento” ao trazer animais que assumem características humanas.

A escolha de animais também não é aleatória, pois na sabedoria popular, o comportamento de muitos animais já se encontra estipulado, ainda que não sejam verídicos e, a partir dessa premissa, o autor da fábula é capaz de poupar detalhes de descrição dos personagens: a raposa é tida como um animal esperto e ágil, assim, o leitor ao se deparar com ela, já reconhecerá suas características ainda que elas não estejam explícitas no texto.

Por fim, o estilo está relacionado com os recursos lexicais, fraseológicos e gramaticais que serão escolhidos a fim de respeitar os objetivos do gênero. Dessa forma, dificilmente veremos uma fábula que se utilize de muitos adjetivos como forma de melhor detalhar o texto, pois isso contradiz seu objetivo de não deixar o leitor se distrair do ensinamento.

Esses três aspectos indissociáveis caracterizam o gênero fábula e poderão variar a depender da esfera em que ela foi/será enunciada, como é o caso de Esopo, Fredo e La Fontaine, mas também como seria o caso de uma fábula enunciada em contexto escolar nos dias de hoje: haverá diferenças, mas esta permanecerá sendo uma fábula se mantiver sua essência: um gênero de fundo popular e crítico que permite ao seu interlocutor refletir sobre

${ }^{19}$ Portella (1983) também ressaltou que não há fábulas com apenas um único personagem. Ainda que o personagem secundário seja um objeto inanimado, ele é indispensável para o estabelecimento de um conflito. 
situações reais de sua vivência. Ainda que haja variações, estas ocorrem sempre a depender do objetivo e do contexto daquele que enuncia e, portanto, sua essência se mantém a mesma.

Finalizamos este tópico com a citação de Rodrigues Arados:

Poucos gêneros literários, se é que existiu algum, apresentam uma maior continuidade que a fábula ao longo de sua história, esta está presente desde a Suméria até os dias atuais. Foi transmitida de literatura em literatura, de língua em língua, produzindo incessantes derivações, imitações, recriações. Sempre igual e sempre diferente, absorveu religiões, filosofias e culturas diversas, que lhe serviram de expressão. Mas também de contraste, pois a fábula carregou sempre um elemento de crítica, realismo e popularismo... Assim, a fábula é um gênero popular e tradicional, essencialmente "aberto", que vive em infinitas variações, como tantos outros gêneros populares. Mesmo os copistas dos manuscritos se viram autorizados a introduzir variações intencionadas de conteúdo, estilo ou língua. Há incontáveis contaminações, prosificações, versificações. As fábulas passam indefinidamente de exemplos soltos a coleções, e vice-versa. E as coleções aumentam ou diminuem seus materiais, se dividem, etc... Para os cínicos, a fábula era uma arma ao mesmo tempo de ensino e de ataque, uma mescla de seriedade e comicidade. Mas logo a fábula voltou a se prosificar, em meio a um conjunto de redações múltiplas, sendo moralizada e usada no ensino geral, não só por parte dos cínicos, mas também por parte das escolas (RODRÍGUEZ ADRADOS, 1979, p. 11-12, tradução nossa) ${ }^{20}$

Como aponta o autor, a fábula se constitui como um dos gêneros que mais foi traduzido entre línguas e culturas, carregando sentidos novos e diferentes, mas, em essência, permanecendo a mesma. Sempre diferente, pois cada língua criará/desenvolverá suas determinadas formas de contar a fábula, a partir de sua lógica, entretanto, os aspectos citados acima dificilmente se alterarão, pois o uso social desse gênero está ligado à um fundo popular e crítico, ainda que tenha sido utilizada com intenções muito diferentes.

Por suas características e por ser um gênero historicamente relacionado à educação (formal ou não formal), seja como ensinamentos no cotidiano ou como exercícios retóricos e,

\footnotetext{
${ }^{20}$ No original: Pocos géneros literarios, si es que existe alguno, presentan una mayor continuidad a lo largo de su historia que la fábula, desde Sumeria hasta nuestros días. Ha pasado de literatura en literatura, de lengua en lengua, produciendo incesantes derivaciones, imitaciones, recreaciones. Siempre igual y siempre diferente, ha absorbido religiones, filosofías y culturas diversas, a las que ha servido de expresión. Pero también de contraste, pues la fábula ha comportado siempre un elemento de crítica, realismo y popularismo...Y es que la fábula es un género popular y tradicional, esencialmente "abierto", que vive en infinitas variantes, como tantos otros géneros populares. Los mismos copistas de los manuscritos se creen autorizados a introducir variantes intencionadas de contenido, estilo o lengua. Hay infinitas contaminaciones, prosificaciones, versificaciones. Las fábulas pasan de los ejemplos sueltos a las colecciones y al revés, indefinidamente. Y las colecciones aumentan o disminuyen su material, se escinden, etc.... Para los cínicos la fábula era un arma al tiempo de enseñanza y de ataque, mezcla de serio y de broma. Pero luego la fábula volvió a prosificarse, en medio de un pulular de redacciones múltiples, moralizándose y usándose en la enseñanza en general, no sólo por parte de los cínicos, sino en las escuelas (RODRÍGUEZ ADRADOS, 1979, p. 11-12).
} 
atualmente, como gênero previsto nos Parâmetros Curriculares Nacionais, o gênero fábula foi escolhido para ser estudado e analisado em Libras.

Cabe, agora, investigar como esse gênero está sendo enunciado pelos reais usuários da língua de sinais, os surdos, em seu principal loci de comunicação: a esfera virtual ${ }^{21}$.

${ }^{21}$ Nessa pesquisa, a esfera virtual é considerada como uma esfera de atividade humana, pois os diferentes espaços que constituem a internet, ou como denominou Martuccelli (2015) a "galáxia internet" (p. 49), são capazes de permitir o encontro e interação entre diferentes sujeitos que, ao enunciarem, se voltam às mais variadas temáticas, a depender do objetivo dos indivíduos e da atividade em que se encontram vinculados. Alguns desses espaços são capazes de replicar esferas já existentes na realidade, o que significa dizer que os gêneros discursivos presentes neles são utilizados de forma semelhante no espaço virtual. Esses espaços, normalmente, como mostraram Martuccelli (2015) e Sorj (2015) são capazes de mediar as relações (assim como as constituições ideológicas e linguísticas) entre o mundo on-line e off-line. Os autores, ao analisarem as transformações nas esferas públicas e nos movimentos sociais na América Latina nas últimas décadas, explicitam possibilidades de ativismo em que seus atores circulam entre o virtual e o real, mas também daqueles que são capazes de realizar ações apenas a partir do virtual. Esse segundo caso nos auxilia a pensar que há espaços e atividades humanas que são específicas do mundo on-line, cujos objetivos dos sujeitos são voltados ao virtual e que resultam em novos enunciados e até gêneros que o mundo off-line, até então, não havia produzido. Sorj (2015) destaca a ação dos “ciber-ativistas” (p. 27) hackers, sujeitos que se utilizam de uma linguagem altamente técnica (própria de sua área de atuação) e, muitas vezes, restrita à internet (como são as linguagens e códigos próprios da programação) e, em coletividade, planejam ações que se voltam para o próprio mundo virtual (como a ação de "derrubar" grandes sítios). Nesse e em outros casos (como programadores ou de comunidades que se voltam para atividades próprias do mundo virtual) é possível perceber que, conforme discutiu Volochínov/Bakhtin (2014), esses campos possuem uma forma própria de compreender e de se orientar para que realidade, forma essa que estará refratada nos sentidos e nos discursos produzidos nesses espaços, podendo inclusive desenvolver enunciados relativamente estáveis. Essa pesquisa, apesar de não se voltar a esses espaços/atividades, se situa na "galáxia internet" e, por esse motivo a considerará enquanto um espaço capaz de abarcar inúmeras esferas de atividade humana. Apesar de utilizar a nomenclatura "esfera virtual” reconhecemos que é impossível pensar na internet como apenas uma única esfera. 


\section{CAPÍTULO IV}

\section{Procedimentos Metodológicos}

Essa pesquisa teve como objetivo saber como se constitui o gênero fábula em Libras na esfera virtual, considerando ser este o principal espaço utilizado pelos surdos para o compartilhamento de textos nesta língua. Dessa forma, o material de análise dessa pesquisa é o discurso, tratando-se, assim, de uma pesquisa qualitativa desenvolvida no âmbito das Ciências Humanas e que assumirá a teoria discursiva e enunciativa de Bakhtin para seu desenvolvimento. Para isso, é preciso entender o discurso como o objeto específico das Ciências Humanas e, de acordo com Amorim (2002), esse objeto que se pretende estudar estará sempre relacionado a um sujeito que é "produtor de discurso e é com seu discurso que lida o pesquisador” (p. 10). Isso implica no encontro entre sujeitos, em encontros com outros e com suas palavras, que não serão percebidas, nesta pesquisa, em seu caráter objetal, enquanto objeto fundamental do conhecimento (BAKHTIN, 1988, p. 151).

Não se pensará ou se estudará os enunciados com o intuito de se identificar o seu sentido original ou único, visto que nesse objeto é possível perceber vozes que carregam sentidos variados. Reconhece-se, no entanto, que construir ou compreender o sentido ali impregnado não é algo simples ou confortável (AMORIM, 2002), pois a pesquisa de situações e interações, não pode ser entendida como uma mera transcrição, na qual se busca manter a originalidade e transparência das enunciações vividas em campo. Ao serem deslocados para o texto científico, os discursos enunciados ganham novos sentidos, pois ao serem trazidos pelo autor da pesquisa, eles aparecem a partir de outro lugar enunciativo e de outro olhar.

Pensar que o discurso é algo transparente é ignorar a instabilidade do próprio objeto e do próprio saber que se constrói no texto de pesquisa; é tomá-lo como uma variável controlável e ignorar o que há de humano na linguagem. O processo de tradução das enunciações vividas em campo para o texto, conforme discutido por Amorim (2004), deve 
sempre ter em vista o lugar enunciativo de onde fala o autor, uma base ideológica e teórica que orienta seu trabalho do início ao fim.

Além disso, nas interações estabelecidas com o outro no campo de pesquisa, o pesquisador deve compreender o sentido da alteridade, deve se envolver, intensamente, no campo para que seja capaz de compreender os modos de ação do outro, inscritos em linguagem. Porém, cabe ao pesquisador também manter uma distância, retomar ao seu lugar enunciativo, para que a compreensão adquirida seja mediada para a interlocução dos sentidos vividos no contexto do campo.

Cabe ao pesquisador transitar entre o que lhe é estranho e familiar, assumindo uma posição exotópica, que é exterior ao seu lugar discursivo. Esse movimento é essencial para a construção do conhecimento na produção do texto científico. Os sentidos construídos na pesquisa carregam consigo, portanto, o lugar teórico de onde o pesquisador fala, sempre considerando e retomando os objetivos de pesquisa, transitando entre as experiências vividas no campo e o seu lugar discursivo.

Nessa postura do pesquisador, é preciso sempre considerar que o fenômeno estudado possui uma dimensão histórica e social das situações e fenômenos que se pretendem estudar, entendida por Góes (2000) como o "curso de transformação que engloba o presente, as condições passadas e aquilo que o presente tem de projeção para o futuro” (p. 13). Como cada enunciação se dá em um contexto vivo, torna-se necessário levar em consideração os sujeitos falantes e as condições concretas de enunciação. Em especial, nesse contexto de pesquisa, que tem como objeto o discurso vivo, ou seja, o estudo da própria língua, torna-se impossível pensa-la separada de seus contextos concretos de enunciação, assim como é impossível analisá-la desconsiderando que ela possui um passado, um presente e um futuro, estando, assim, sempre em constante transformação, em evolução.

No caso de um estudo que busca estudar os gêneros discursivos, ressaltamos o que discutiu Machado (2012): é impossível pensar o conceito de gênero desvinculado de sua dimensão “espaçotemporal”, em suas situações cronotrópicas particulares e recorrentes. Dessa forma, é impossível um estudo genérico que não leve em consideração as esferas e o momento histórico em que as enunciações foram realizadas. 


\section{IV.1 Coleta de Dados}

Para o desenvolvimento desta pesquisa foi realizada, inicialmente, uma pesquisa na plataforma YouTube, por meio da qual buscou-se videogravações produzidas em Libras, por sujeitos surdos, sobre textos de um dos gêneros previstos no Parâmetros Curriculares Nacionais - Língua Portuguesa, para os anos iniciais: a Fábula. Essa escolha considerou que já existem textos e pesquisas que discutem gêneros secundários presentes no espaço escolar (como conto de fadas e histórias infantis); entretanto, no caso da Fábula, o mesmo não pode ser dito.

Para a busca destes textos foram utilizadas as seguintes palavras-chaves: "Fábulas Libras”, “Fábulas em Libras” e “Surdo Fábula”. A variação no número de vídeos a partir das palavras de busca não trouxe resultados diferentes, razão pela qual não foi necessário categorizar os dados segundo este critério.

A seleção dos vídeos foi realizada no segundo semestre de 2016, e, portanto, não foram incluídos na amostra vídeos publicados posteriormente a esse período. Vale ressaltar ainda que, durante o processo de tratamento dos dados, um dos vídeos selecionados foi deletado da plataforma YouTube o que resultou em sua exclusão do corpo da análise.

A aproximação com o objeto de estudo visou conhecer como esse gênero tem sido compreendido e utilizado pelas pessoas surdas, usuárias da Libras, nos espaços que constituem a esfera virtual, principal loci em que os surdos compartilham informações nesta língua. Compreende-se, desse modo, a esfera virtual como um espaço de possibilidade de registro e de perpetuação de enunciados em língua de sinais. Nos espaços dentro da esfera virtual, não há uma restrição de temática ou de objetivos em relação aos conteúdos produzidos; sua função é, principalmente, a divulgação e o registro dos discursos, fato que permite a submissão de textos em Libras envolvendo diferentes temas - entre ele, fábulas. Por esses motivos, consideramos o virtual como um local privilegiado para perceber as transformações e estabilizações relativas de determinados gêneros secundários em Libras.

Visto a especificidade da esfera virtual, a seleção e exclusão de vídeos para a análise foi feita pensando na "orientação" dos textos, ou seja, se eles foram ou não produzidos para a internet ou para alguma outra forma de mídia que tivesse por objetivo a divulgação de textos de fábulas em Libras.

Para a identificação dos sujeitos dos vídeos, a fim de garantir enunciados produzidos unicamente por surdos, após a seleção do texto em vídeo, buscou-se os perfis sociais on-line 
dos autores. Foram encontrados um total de 25 vídeos sinalizados por sujeitos surdos; os demais, enunciados por ouvintes, foram descartados das análises.

Observou-se, durante a seleção dos vídeos, que alguns textos eram enunciados por apenas um sujeito, enquanto outros eram construídos por meio da participação de mais de um participante; por este motivo, a quantidade total de vídeos é diferente da quantidade total de sujeitos encontrados. Um total de 27 sujeitos participou dos vídeos selecionados: 14 homens e 13 mulheres. A faixa etária dos autores dos textos também diferiu: 24 sujeitos eram adultos, com idades que variavam entre 20 e 50 anos, e 3 eram menores de idade. Como estes últimos se encontravam em situação de escolarização, dentro de salas de aula e na presença de professores ou colegas de turma, foram identificados como sendo alunos.

Os vídeos foram selecionados, inicialmente, por possuírem o título fábulas. Descartaram-se vídeos que, mesmo apresentando alguma das palavras-chaves, não se constituíam como a narrativa de fábulas em Libras (como vídeos de narrativas de fábulas unicamente em língua portuguesa, ou textos voltados a temáticas sobre a Libras, os surdos e a surdez de forma geral).

Na seleção realizada, buscou-se observar se havia ou não a existência de formas relativamente estáveis de enunciados nos textos produzidos, de forma a responder se os textos poderiam ser reconhecidos por suas características genéricas, ou se ainda se encontram em um estágio inicial de formação. As fábulas mais presentes nessa seleção foram "O Leão e o Ratinho” e “A Lebre e a Tartaruga”. Ambas possuem autoria atribuída à Esopo e se constituem como narrativas tradicionais da leitura em língua portuguesa.

\section{IV.2 Vídeos selecionados e critérios de exclusão}

Na tabela a seguir serão apresentados os dados relativos à quantidade de vídeos encontrados, diferenciando-os em aqueles enunciados por surdos e por ouvintes.

TABELA 1 - Vídeos encontrados

\begin{tabular}{l|l}
\hline \multicolumn{2}{c}{ Vídeos Encontrados } \\
\hline Vídeos & Quantidade \\
\hline Surdos & 25 \\
\hline Ouvintes & 49 \\
\hline Não identificados & 2 \\
\hline Total & 76 \\
\hline
\end{tabular}


No total de 76 vídeos encontrados, que correspondiam à temática estipulada pelas palavras-chaves, 25 foram identificados como sendo enunciados por sujeitos surdos e 49 por ouvintes. Dois (2) vídeos foram categorizados como “não identificados” devido a impossibilidade de encontrar perfis on-line que identificassem os sujeitos enquanto surdos ou ouvintes. Estes vídeos de sujeitos não foram incorporados à amostra e, portanto, não foram analisados.

A esfera virtual constitui-se em um local de convivência de muitas línguas, culturas, idades, gêneros etc; em especial, a plataforma YouTube, que não apresenta restrições ${ }^{22}$ quanto aos tópicos citados. Neste convívio entre línguas, encontram-se também textos enunciados em Libras e em língua portuguesa, por falantes de ambas as línguas.

Chamou a atenção, no levantamento realizado, a grande quantidade de vídeos produzidos por ouvintes enunciando em Libras. Embora seja se trate de uma esfera virtual, nele são produzidos enunciados concretos por sujeitos reais, sendo assim, torna-se possível afirmar que as relações entre surdos e ouvintes, que compartilham esferas concretas de atividade, sejam também estabelecidas neste espaço. Nela, portanto, instauram-se também tensões e assimetrias de poder linguístico e de relações no convívio de enunciados que carregam culturas distintas; além de haver a possibilidade da hibridização na produção de enunciados da Libras, processo este esperado quando se há contato entre línguas.

Os objetivos dos vídeos produzidos também variaram no interior e entre os grupos de ouvintes e surdos. A fim de melhor apresentar estes contextos, foram organizadas outras duas tabelas: na primeira serão apresentados os propósitos dos discursos produzidos por ouvintes para, em seguida, serem mostrados e discutidos os textos enunciados por surdos.

\section{TABELA 2 - Categorização dos vídeos enunciados por ouvintes}

\begin{tabular}{l|l}
\hline \multicolumn{2}{c}{ Vídeos Enunciados por Ouvintes } \\
\hline Contexto & Quantidade \\
\hline Tradutores e Intérpretes de Libras & 7 \\
\hline $\begin{array}{l}\text { Trabalhos de Conclusão de } \\
\text { Cursos/Disciplinas }\end{array}$ & 42 \\
\hline Total & 49 \\
\hline
\end{tabular}

\footnotetext{
${ }^{22}$ As restrições previstas nos termos de uso do YouTube dizem respeito ao seu uso por menores de idade sem a permissão dos pais (logo, sem possuírem conta) e à conteúdos não autorizados.
} 
Na tabela 2, é possível observar que 7 vídeos foram identificados como “Tradutores e Intérpretes de Libras”, por ser esta a ocupação dos sujeitos que enunciam nesses textos e, cumprindo seu papel, propuseram-se a traduzir/interpretar fábulas da língua portuguesa para a Libras, conforme constava nas descrições dos vídeos. Essas produções resultaram, em sua maioria, em um acompanhamento da narrativa por meio de imagens e escritas da história original. Não foi possível identificar, entretanto, se esses trabalhos foram construídos em parceria com sujeitos ou organizações surdas, mas, ao terem um ouvinte como enunciador, tais vídeos foram desconsiderados, visto que esses, embora produzidos em Libras, por mais fluentes que fossem os produtores dos textos, os estava enunciando em uma segunda língua (L2), carregando, involuntariamente, sentidos e concepções de mundo que não são iguais as enunciações própria de surdos que têm a Libras como primeira língua (L1).

Os vídeos restantes, num total de 42, foram categorizados como trabalhos de conclusão de disciplinas voltadas para o ensino de Libras. Não foi identificada, entre os alunos participantes, a coautoria de surdos. Tais vídeos apresentavam tentativas de interpretação de fábulas do português para a Libras propostas com fins avaliativos dos cursos e, portanto, foram enunciados por aprendizes da língua, que, por este motivo, deixavam fortes marcas da língua portuguesa ao se preocuparem com uma correspondência termo a termo entre palavras do português e sinais, além de desconsiderarem especificidades da Libras fundamentais para a construção de sentidos nesta língua, como por exemplo, expressões faciais e referências espaciais.

\section{TABELA 3 - Categorização dos vídeos enunciados por surdos}

\begin{tabular}{l|l}
\hline \multicolumn{2}{c}{ Vídeos Enunciados por Surdos } \\
\hline Contexto & Quantidade \\
\hline Surdos Enunciando & 17 \\
\hline Professores de Escolas/Cursos & 2 \\
\hline Trabalhos Conclusão de Curso & 3 \\
\hline Alunos Narrando & 3 \\
\hline Total & 25 \\
\hline
\end{tabular}

Na terceira tabela, os 25 vídeos produzidos por surdos foram categorizados também a partir de diferentes contextos de enunciação. Foram observados textos que foram, para esta análise, denominados “Surdos Enunciando”: vídeos produzidos por surdos com as intenções de registro e divulgação de narrações de fábulas em Libras, produzidos em diferentes períodos 
e associados a diferentes objetivos; textos narrados por "professores de escolas/cursos” e que, portanto, visavam, com o vídeo, levar os alunos à aprendizagem/reflexão da Libras (não foi possível identificar se o ensino da Libras era voltado a surdos ou ouvintes, e nem em que nível de ensino); vídeos de alunos ou professores surdos identificados como sendo trabalhos de conclusão de cursos de Letras/Libras; e vídeos de alunos surdos, em situações de aula, narrando/recontando/apresentando fábulas em Libras.

Na primeira categoria de vídeos, "Surdos Enunciando”, foi possível perceber que estes não pertenciam à um contexto pedagógico; eram vídeos elaborados por surdos na esfera virtual com objetivos e períodos distintos. Desta categoria, foram selecionados para a análise 11 (onze) textos e excluídos 6 (seis) por se tratarem de dramatizações, contos e parábolas.

No que diz respeito às dramatizações, três vídeos assim narravam as fábulas. Os autores se encontravam caracterizados (com roupas e maquiagens) e encenavam as falas e ações dos personagens em meio a um cenário; as histórias tornavam-se longas e traziam certa leveza se em comparação ao que se é esperado em uma fábula. Reconhece-se que há diferentes formas de se contar um fábula, entretanto, considerando as especificidades deste gênero discutidas no Capítulo III deste trabalho, compreendeu-se que essa forma de narrativa aproximou-se mais de um teatro do que de uma fábula, visto que há um maior foco nos detalhes narrativos e o esquecimento de seu caráter pedagógico. Além disso, as morais típicas da fábula não foram encontradas de forma implícita ou explícita nos textos; espera-se, portanto, que o interlocutor conclua por conta própria, quais qualidades e defeitos estão presentes nos personagens e/ou quais atitudes seriam positivas/negativas.

Outros dois vídeos transformaram a narrativa das fábulas em textos muito mais próximos de contos: são vídeos longos (chegam a ter quase 10 minutos de narrativa) que tem como foco o contar a história. Em sua construção, deixam marcas explicitas de serem adaptações/aproximações da história com outras histórias construídas por meio de imagens ou vídeos $^{23} \mathrm{e}$, da mesma forma como ocorria com as dramatizações, ignoravam o ensinamento oculto por trás da narrativa, por trás da ação alegórica.

Foi encontrado ainda um vídeo que foi categorizado pelas pesquisadoras como parábola. Não foi possível identificar a autoria do texto em português, intitulado “O Escorpião e a Tartaruga”, que deu origem a enunciação do vídeo selecionado. Entretanto, a partir das diferenciações, apontadas por Portella (1983), entre as características de uma fábula e de uma

\footnotetext{
${ }^{23}$ Um vídeo que se propõe a contar a fábula “O Leão e o Ratinho” o faz da seguinte maneira: narra-se um trecho da história e, logo em seguida, traz a cena de um filme infantil para ilustrá-la.
} 
parábola, foi possível reconhecer que o ensinamento implícito nesse texto não está relacionado à sabedoria popular (à uma sabedoria efêmera que pode ser compreendida de formas diferentes em contexto diferentes), mas sim trazia com ele um valor que "vale sempre" (p. 125), tal qual a real natureza das pessoas e, no caso do texto em questão, do escorpião. Por este motivo, este vídeo foi excluído do corpo das análises.

A segunda categoria de vídeos selecionados, "Professores de Escolas/Cursos", constituiu-se em um conjunto de textos produzidos em situações de sala de aula, nas quais o docente que enuncia foi filmado, provavelmente, por um de seus alunos. Identificou-se, dessa forma, que os textos são pertencentes à esfera escolar e que, portanto, seus interlocutores são seus alunos. Pela especificação do contexto em que se encontravam os sujeitos, foi possível perceber que o objetivo do enunciador não era, unicamente, o registro da narração de fábulas, mas também possibilitar aos alunos a aprendizagem da Libras, razão pela qual usavam a língua de forma vagarosa, com pausas e/ou repetições desnecessárias de sinais. Por este motivo, esses vídeos foram também excluídos do escopo da análise. Dois dos vídeos inicialmente incluídos nessa categoria foram re-categorizados como "Surdos Enunciando", pois apesar dos sujeitos se encontrarem em ambientes escolares, eles não assumiam a posição de professor em contexto de aula.

A terceira categoria diz respeito à três vídeos identificado como produções de professores e alunos voltadas para disciplinas de "literatura surda” do Curso de Letras: Libras. Assim, encontrou-se um texto denominado “Arara Surda e Boi surdo”. Por não ter sido possível encontrar alguma fábula semelhante em português, que pudesse ter servido como base para a elaboração do vídeo, considerou-se que o mesmo se tratava de uma criação do autor do vídeo. Apesar de se identificar enquanto fábula, a temática do vídeo era voltada para a narração da história dos personagens, não possuindo um ensinamento; a sua forma composicional também difere do esperado, o foco da narrativa se encontra nas formas de enunciar de cada personagem e não em um conflito propriamente dito. Por este motivo, esse vídeo não foi também analisado. Os demais vídeos, apesar de serem narrativas de fábulas esópicas, foram narrados em contextos escolares, apresentando problemas semelhantes ao da categoria anterior.

Por fim, a quarta categoria, “Alunos Narrando”, foi constituída por vídeos de alunos menores de idade, em situações escolares, contando fábulas. Nesse caso, esses vídeos foram compreendidos como sendo realizados por sujeitos que ainda se encontram em processos de assimilação da Libras (em diferentes níveis), enunciando a fábula a partir do modelo de um 
professor. Embora não tenha sido possível identificar se, no caso, os professores envolvidos eram ouvintes bilíngues ou surdos, inferiu-se serem ouvintes ao se perceber as fortes marcas da língua portuguesa na organização discursiva dos alunos, assim como descrito anteriormente. Por esse motivo, os vídeos dessa categoria não foram analisados.

Os vídeos selecionados para análise no Capítulo V deste trabalho foram organizados e separados a partir de seus objetivos, sendo divididos em duas seções: "vídeos com fins de divulgação de língua” e “vídeos com fins políticos”.

\section{IV.3 Transcrição de dados}

Considerando que os objetivos desse trabalho se voltam para a constituição de enunciados em Libras, optou-se por uma transcrição que conseguisse respeitar, dentro do possível, as especificidades discursivas desta língua, pois uma tradução dos dados coletados para o português, poderia alterar a forma e as características observadas na forma como as fábulas foram enunciadas.

Para a realização das transcrições foi utilizado o padrão descrito por Lodi (2004), que, em função dos objetivos desta pesquisa, foi adotado de forma simplificada.
a) Sinais: EM LETRA MAIÚSCULA;
b) Gestos e direcionamento de olhar: (descritos entre parênteses);
c) Linguagem oral: em itálico;
d) Alfabeto manual: EM NEGRITO E EM LETRA MAIÚSCULA;

Outros elementos propostos pela autora também foram utilizados:

1. A transcrição dos verbos em Libras para o português foi realizada sempre na forma infinitiva;

2. Na transcrição, foram mantidos os pronomes da forma como enunciados em português, inclusive quando estes forem incorporados nas flexões verbais (neste caso, apareceram em subscrito);

3. Foram mantidas as marcações de número e gênero com base no contexto da enunciação;

4. Artigos e preposições, por serem incorporados na organização gramatical espacial dessa língua, não constaram das transcrições; 
5. No caso do uso do alfabeto manual, as letras foram separadas por hífen. Naqueles casos em que mais palavras foram digitadas em sequência, essas foram separadas por \#;

6. Para enunciados envolvendo interrogações e exclamações, foi utilizada a pontuação do português (? e !).

7. A notação de negativa, quando essa ocorrer por movimentação de cabeça sem estar inserida no sinal, foi realizada pelo símbolo (...ñ...) transcrito acima de seu sinal correspondente;

8. Quando forem utilizadas duas ou mais palavras em português para a expressão de um conceito que, em Libras, é enunciado por um único sinal, as palavras apareceram ligadas por hífen;

9. No caso de uso de classificadores foi indicado o sentido do sinal seguido da sigla (Cl);

10. Para a indicação de ações realizadas simultaneamente foi utilizado ( [ ) entre as transcrições;

11. A indicação de que a fala foi tomada ou interrompida em determinado ponto e não em seu início foi indicada por: (...).

\section{IV.4 Análise dos dados}

Essa pesquisa buscou responder a quatro questões principais:

1. Com quais propósitos estes gêneros foram enunciados?

2. Quais os processos enunciativos constitutivos do gênero em Libras a partir do contexto de produção investigado?

3. Quais as especificidades discursivas encontradas no tema, estilo e forma composicional das fábulas?

4. Eles diferem da forma como o concebemos em português?

Visto que este é um estudo dos processos enunciativos da língua e que esta vive e evolui historicamente na comunicação verbal, foram utilizados os princípios descritos por Volochínov/Bakhtin (2014) ao discutir a ordem metodológica para o estudo da língua que considere o seu caráter vivo e a natureza das enunciações: 
Disso decorre que a ordem metodológica para o estudo da língua deve ser o seguinte:

1. As formas e os tipos de interação verbal em ligação com as condições concretas em que se realiza.

2. As formas das distintas enunciações, dos atos de fala isolados, em ligação estreita com a interação de que constituem os elementos, isto é, as categorias de atos de fala na vida e na criação ideológica que se prestam a uma determinação pela interação verbal.

3. A partir daí, exame das formas da língua na sua interpretação lingüística habitual.

É nessa mesma ordem que se desenvolve a evolução real da língua: as relações sociais evoluem (em função das infra-estruturas), depois a comunicação e a interação verbais evoluem no quadro das relações sociais, as formas dos atos de fala evoluem em conseqüência da interação verbal, e o processo de evolução reflete-se, enfim, na mudança das formas da língua (VOLOCHÍNOV/BAKHTIN, 2014, p. 128).

Dessa forma, as análises realizadas nesse trabalho partiram das condições reais em que as enunciações ocorreram, para a análise dos detalhes e das condições de criação ideológica em que tais enunciações foram produzidas para, enfim, examinar as formas da língua e os sentidos que ali se instauraram. Para isso, tornou-se necessário considerar não apenas aquilo que estava sendo dito verbalmente, mas também o extraverbal (BAKHTIN, 2014, p. 129), as expressões, as tensões ou conflitos e a forma como o indivíduo posiciona seu corpo e direciona seu olhar. Todos esses detalhes auxiliaram na compreensão das diferentes vozes presentes e, logo, contribuíram para a construção de sentidos dos textos.

Em alguns casos, não foi possível a identificação da situação de produção do texto ou a quem o discurso se dirigia; no entanto, os sentidos neles em circulação possibilitaram a compreensão da intenção da criação do vídeo e, portanto, da possível intenção do autor na elaboração de tais enunciados. Essa intenção poderá ser percebida ao se considerar que ela reflete diretamente nas escolhas discursivas e na maneira como o sujeito enunciava.

O estudo de um gênero exigiu, ainda, que o compreendêssemos como uma unidade aberta e em constante transformação (MACHADO, 2012), e que, apesar de possuir formas relativamente estáveis de enunciado, estão sempre suscetíveis a mudanças toda vez que são utilizados. Nessa pesquisa em especial, foi preciso ainda considerar que a fábula é um gênero histórico e que seus textos em língua portuguesa sofreram, nos vídeos analisados, um processo de tradução para a Libras, o que implicou em um deslocamento de seus contextos, sentidos e interlocutores. Nesse sentido, as análises consideraram que as escolhas enunciativas 
dos sujeitos surdos seriam distintas daquelas produzidas em língua portuguesa, visto que os textos foram enunciados a partir das especificidades discursivas e da materialidade da Libras.

Nesse processo, buscou-se, ainda, observar as maneiras pelas quais os sujeitos transmitiram a palavra citada (VOLOCHÍNOV/BAKHTIN, 2014) ao assimilarem a palavra de outrem (BAKHTIN, 1988), fato que determinou formas distintas de construção e estabelecimento de sentidos nas obras. 


\section{CAPITULO V}

\section{Análise dos dados}

Neste capítulo serão analisadas 11 (onze) fábulas enunciadas por sujeitos surdos, em vídeos, para a esfera virtual. É importante ressaltar que todos os vídeos tiveram como base, ainda que não explicitem a fonte, fábulas já existentes em língua portuguesa e que são de autoria de Esopo ou de La Fontaine. Dessa forma, tratam-se de traduções realizadas do português (língua fonte - LF) para a Libras (língua alvo - LA) ${ }^{24}$.

Sobral (2008), em seu livro sobre o papel e exercício do tradutor, discutiu questões bastante interessantes sobre o ato de traduzir que colaboraram para a compreensão das escolhas discursivas realizadas pelos surdos para a elaboração dos vídeos analisados. Entretanto, é preciso destacar que os sujeitos surdos não são tradutores (ou não se autoidentificaram como tal) no sentido profissional da palavra; mas, ao proporem a narrativa de fábulas históricas em Libras, foram assim compreendidos nesta dissertação. Nesse sentido, torna-se necessária uma discussão, mesmo que breve, sobre como a prática de tradução foi entendida neste estudo.

Para Sobral (2008), traduzir implica sempre em uma transfiguração, em uma interpretação, em uma recriação; significa ocupar o lugar de autor a fim de reorganizar as ideias para um novo fim, em uma nova lógica linguística. Dessa forma, o ato de traduzir, para o autor, não significa copiar ou repetir um texto enunciado anteriormente na LF para a LA; não pode ainda ser compreendido, a partir do que Bakhtin (1988) chamou de exercício de reprodução “de cor” (p. 142), ao mesmo tempo em que não se reduz a uma reprodução "com suas próprias palavras” (p. 142), ainda que no texto traduzido seja possível perceber a bivocalidade. Ao traduzir, o sujeito se encontra em um meio termo, pois apesar de realmente criar um novo discurso, deve garantir que os sentidos presentes no texto da LF se estabeleçam a partir dos sentidos existentes e da lógica de uma nova língua. É nesse contexto que Sobral (2008) defende que o tradutor deve ser capaz de dizer o "mesmo” a outras pessoas.

Assim, quando o tradutor retira um texto de um contexto histórico e linguístico específico, no qual ele foi produzido, para integrá-lo em outro, cabe ao profissional buscar correspondências entre as línguas, “definidas como recursos de criação de sentido de uma

\footnotetext{
${ }^{24}$ Nomenclatura utilizada por Sobral (2008).
} 
língua que podem ser recriados por meio de recursos de outra língua, para produzir efeitos de sentido semelhantes” (p. 76). Isso só é possível, pois, como demonstrou o autor, as línguas não são completamente semelhantes (pois nesse caso a tradução seria dispensável) e também não o são completamente diferentes (visto que nesse caso a tradução seria impossível), mas são constituídas a partir de um mesmo material: o signo ideológico. Dessa forma, os efeitos de sentido são criados a partir de uma cultura, ou seja, a partir de formas singulares de significar o mundo. O tradutor, portanto, não buscará traduzir os sentidos, mas sim encontrar formas correspondentes de expressar o "mesmo" a partir da lógica discursiva e semiótica da LA.

No que diz respeito à maneira de se analisar um texto traduzido, Sobral (2008), com base na teoria enunciativa de Bakhtin, propôs que ela seja feita a partir da completude do texto, ou seja, que ele seja compreendido enquanto um discurso que tem uma intencionalidade, uma direção (à outros) e uma avaliação valorativa; apenas ao se considerar esse discurso em sua situação de uso concreto, será possível perceber os processos de negociação e estabilização de sentidos no interior dos textos.

Cabe ainda ressaltar que, como apontou Sobral (2008), os textos traduzidos não se constituem enquanto o gênero da LF, mas sim enquanto uma derivação desse gênero. Dessa forma, não será um gênero inteiramente novo, mas também não será o gênero da LF, pois trará, necessariamente consigo, as concepções de mundo intrínsecas a LA.

Desse modo, a partir das considerações realizadas nos Capítulos II e III, sobre a natureza da língua compreendida a partir da teoria enunciativa de Bakhtin, e sobre as particularidades dos processos de tradução apontadas por Sobral (2008), os vídeos das fábulas em Libras foram analisados nesta dissertação.

Observou-se, no conjunto dos vídeos analisados, a existência de dois projetos enunciativos distintos, fato que determinou que as análises fossem divididas em duas sessões. A primeira foi composta por 9 (nove) fábulas que foram enunciadas com o propósito de divulgação e/ou ensino da Libras; a segunda foi composta por 3 (três) vídeos, que foram produzidos a fim de chamar a atenção dos surdos sobre problemáticas envolvendo questões políticas relativas à comunidade surda, o que possibilitou um maior diálogo entre a fábula e a vida. 


\section{V.1. Vídeos com fins de divulgação e/ou ensino da Libras}

\section{V.1.1 Apresentação dos vídeos}

Foram analisados, neste tópico, 9 (nove) vídeos que, no processo de categorização, foram identificados como desenvolvidos para fins de divulgação e ensino da Libras, com a intenção de criar textos que pudessem servir como base para o conhecimento da língua, ou servir para a criação de materiais didáticos pedagógicos voltados à educação de surdos.

Seis dos nove textos encontram-se agrupados em um único vídeo (que será chamado de compilação ao longo das análises) e foram enunciados por um mesmo sujeito. Originalmente, esse material foi produzido em VHS e sua produção data do início dos anos $2000^{25}$. Há alguns anos ele foi disponibilizado na plataforma YouTube. Importante destacar que, no período em que ele foi filmado, as discussões a respeito dos surdos e de sua língua ainda estavam começando a ganhar forças no contexto brasileiro, visto que o vídeo foi produzido em um momento posterior à criação do documento "A educação que nós surdos queremos”26, de abril de 1999, ao mesmo tempo em que antecede grandes marcos políticos para este grupo sociocultural, como a Lei ${ }^{\circ} 10.436 / 02$ e o Decreto $n^{\circ} 5.626 / 05$. Tratava-se, portanto, dos primórdios das discussões sobre educação bilíngue para surdos no Brasil, vinculada à uma forte luta voltada ao reconhecimento linguístico da Libras.

A produção do vídeo foi realizada por uma empresa com fins comerciais, que tem como objetivo produzir materiais didáticos pedagógicos dedicados a pessoas surdas ou ouvintes interessadas na aprendizagem da língua de sinais, visando, de acordo com a descrição que se encontra no site da empresa, a difusão da língua com a intenção de “contribuir para a melhoria de vida e da educação dos surdos”27. Por não ser um material produzido unicamente para surdos, o vídeo foi constituído também por legendas em língua portuguesa. Estas, porém, foram elaboradas a partir da escrita de um livro ${ }^{28}$ sobre as "Fábulas

\footnotetext{
${ }^{25}$ O título do vídeo na plataforma YouTube é “6 Fábulas de Esôpo em Libras”; em sua versão original ele foi denominado “6 Fábulas de Esopo em Língua de Sinais Brasileira”.

${ }^{26}$ Trata-se de um documento elaborado pela comunidade surda, no qual foram realizadas propostas para se pensar uma educação de surdos que respeite a língua brasileira de sinais (fundamental para a educação e desenvolvimento dos alunos surdos), e que privilegie a presença de profissionais surdos nos espaços escolares. $\mathrm{O}$ documento foi organizado a partir de três grandes tópicos: "Políticas e práticas educacionais para surdos", “Comunidade, cultura e identidade” e "Formação do profissional surdo”.

${ }^{27}$ Trecho retirado do site da empresa. Disponível em: https://www.lsbvideo.com.br/lsb-video. Acesso em julho de 2017.

${ }^{28}$ A introdução da compilação e a ordem de narração das fábulas se assemelham à escrita do livro "Fábulas de Esopo” (ASH; HIGTON, 2016). Apesar de a edição encontrada ser de 2016, esta se trata da 34 reimpressão do livro; sua primeira edição data de 1994. Dessa forma, apesar de não ser referenciada como fonte, essa possibilidade não pode ser descartada.
} 
de Esopo”, não retratando, em diferentes momentos, o que está sendo enunciado em Libras. Outro aspecto que chamou a atenção, foi o fato de as narrativas das fábulas serem entremeadas por imagens que visam retratar o momento do texto que foi enunciado.

Apenas duas pessoas surdas enunciam no vídeo: o sujeito A, responsável pela introdução, pela narração das fábulas e pela explicação/comentários sobre a moral; e o sujeito B, responsável pela explicação do que é uma fábula e pela apresentação de glossários.

Na introdução há a explicitação dos objetivos para a elaboração do material: a necessidade de se contar mais histórias em Libras, ao se considerar a não existência de materiais nesta língua (no vídeo se afirma ser aquele um trabalho inédito de narração de fábulas em língua de sinais). Tem-se aqui, portanto, a intencionalidade do vídeo: a de aproximar surdos e ouvintes da Libras. Esta informação foi ainda complementada pelo sujeito A quando ele explicitou à quem este vídeo foi "endereçado": à pessoas surdas e ouvintes, instrutores ou professores, ou ainda à ouvintes que sabem Libras e que ensinam/trabalham com crianças surdas ${ }^{29}$. Posterior à esta introdução, houve uma pequena apresentação do que é uma Fábula, realizada pelo sujeito B, assim como do que é uma moral. Durante essa explicação, foi contada as origens da fábula, diferenciando-se o que é “corpo” - a forma composicional e o estilo - e a "alma” da fábula - o tema.

O gênero foi descrito como sendo histórias simples, engraçadas e curtas ${ }^{30}$, que podem ser comparadas com a vida; apresentam uma moral ao final, com o intuito de fazer com que o interlocutor perceba as comparações possíveis entre a história e a vida ${ }^{31}$. Além disso, foram explicitadas as características alegóricas da fábula, ou seja, a presença de animais com qualidades e comportamentos humanos. Em seguida, o sujeito A destacou que, após a narrativa de cada fábula haveria um glossário (palavra-sinal) dedicado especialmente aos ouvintes que estão aprendendo Libras ${ }^{32}$.

\footnotetext{
${ }^{29}$ No vídeo, o sujeito A enuncia: "[VIDEO] BOM APRESENTAR PESSOAS SURDAS OU OUVINTES OU AMIGOS OU FAMÍLIAS OU OUVINTES SABER LIBRAS ENSINAR SURDO CRIANÇA TRABALHAR OU INSTRUTORES PROFESSORES DIVERSOS” ([o vídeo é] bom para ser apresentado a pessoas surdas ou ouvintes ou amigos ou familiares ou ouvintes que sabem Libras para o ensino da criança surda ou a instrutores e professores diversos)

${ }^{30}$ Na versão do livro "Fábulas de Esopo" (2016), essa explicação é feita da seguinte forma: “As fábulas de Esopo costumam ser curtas e bem humoradas, transmitindo em linguagem simples mensagens relacionadas ao comportamento no cotidiano, com singelos conselhos sobre lealdade, generosidade e virtudes do trabalho" (ASH; HIGTON, 2016, p. 6).

${ }^{31}$ No original: F-A-B-U-L-A-S CONTAR HISTÓRIAS SIMPLES ENGRAÇADAS CURTAS MOSTRAR COMPARAÇÃO VIDA, TAMBÉM MORAL FIM. MORAL É VOCÊ PERCEBER VIDA, COMPARAR COMO VIDA.

${ }^{32}$ No vídeo, o sujeito A enuncia “(...) BOM VOCÊ OUVINTE APRENDER AJUDAR LIBRAS”, não havendo referências, dessa forma, de que o vocabulário possa servir também aos surdos.
} 
Finalizada a apresentação do vídeo, o sujeito A realizou a narração de seis fábulas ${ }^{33}$ : “A Lebre e a Tartaruga”(1) $)^{34}$, “O Sapo e o Boi”(2), “O Lobo e a Cegonha”(3), “A Reunião dos Ratos”(4), “O Leão Apaixonado”(5) e a “Queixa do Pavão”(6) ${ }^{35}$; ao término de cada fábula houve a apresentação da moral em língua portuguesa, uma pequena explicação sobre a moral em Libras e, por fim, o glossário de sinais.

O sétimo vídeo, foi narrado pelo indivíduo denominado nesse trabalho por sujeito $\mathbf{C}$ e é datado de $2016^{36}$. O vídeo pertence a um canal específico destinado a divulgação da Libras e nele é possível encontrar textos que versam sobre os mais variados temas, "visando colocar a língua de sinais em primeiro plano” (trecho extraído da descrição do canal na plataforma YouTube). O canal ainda disponibiliza legendas em português, com o intuito de auxiliar ouvintes aprendizes da Libras.

O vídeo trata da narração da fábula denominada “O Jovem Pastor e o Lobo”(7) ${ }^{37}$ que, nesse contexto, foi utilizada para ilustrar uma explicação e contextualização sobre o "dia da mentira” ( $1^{\circ}$ de abril). O enunciador explicitou que as imagens que também constituem o texto possuem como fonte o vídeo produzido pelo canal do Discovery Kids - Brasil ${ }^{38}$, que narra esta mesma fábula em língua portuguesa. É importante ressaltar que, mesmo que o texto em si não seja referenciado, foi possível perceber seu uso para a construção das legendas em português e para a apresentação da moral ao final do vídeo.

Como características comuns aos sete vídeos pode-se destacar a constante interrupção das narrativas dos vídeos por imagens para exemplificar o que acabava de ser narrado e a apresentação dos títulos das fábulas em português escrito. Observa-se assim que a estrutura dos textos se assemelhou a dos livros infantis, nos quais a narrativa de uma situação sempre vem acompanhada de uma imagem explicativa e/ou complementar; entretanto, no caso dos vídeos em Libras, avaliou-se que essa prática prejudicou a fluidez dos vídeos, na medida em que os autores foram obrigados a interromper e a retomar suas falas após as imagens.

Por fim, os últimos dois vídeos analisados foram enunciados pelo sujeito $\mathbf{D}$ e são datados de outubro de 2013. O autor se encontrava na Associação de Surdos do município

\footnotetext{
${ }^{33}$ As fábulas em língua portuguesa se encontram nos anexos desse trabalho.

${ }^{34}$ Cada número representará uma fábula nas análises desta seção.

${ }^{35}$ Essa mesma ordem de fábulas compõe as seis primeiras fábulas do livro "Fábulas de Esopo” (ASH; HIGTON, 2016).

${ }^{36}$ Ou seja, posterior a todos os marcos legais de educação bilíngue discutidos do Capítulo 1 dessa dissertação.

${ }^{37}$ Essa fábula possui variações de título em português, tal qual "O Garoto do 'Olha o Lobo”” (ASH; HIGTON, 2016).

${ }^{38} \mathrm{O}$ vídeo encontra-se disponível em: https://www.youtube.com/watch?v=gY6mvFfsDoc
} 
onde mora, conforme descrição que consta no vídeo, em um espaço físico voltado ao ensino da Libras ${ }^{39}$; no entanto, o vídeo não foi realizado em situação de ensino da língua, visto que o autor encontrava-se de costas aos presentes, não estabelecendo nenhum diálogo com as pessoas que se encontravam sentadas na sala. Entretanto, ao se considerar a instituição onde ele foi realizado, inferiu-se que seu objetivo fosse também o de divulgação e ensino desta língua.

Nos vídeos foram narradas duas fábulas de Esopo: “O Leão e o Rato” (8) e "O Cão e o Naco de Carne” (9). Não há, no vídeo ou na descrição deste, referências à utilização de textos base e, diferentemente dos demais analisados, os vídeos de autoria do sujeito $\mathbf{D}$ não possuem legendas ou a utilização de imagens. De todos os textos analisados nesta seção, os do sujeito D foram os mais curtos e densos, possuindo 41 segundos (8) e 25 segundos (9).

Todos os textos apresentaram as principais características do gênero fábula tal como o concebemos em língua portuguesa: são curtos (o maior foi enunciado em 3 minutos e 54 segundos e o menor em 25 segundos), com a presença de uma ação alegórica - personagens com qualidades humanas que vivem um conflito - ocultando um ensinamento. Essa lição foi incorporada de diferentes formas pela compilação, pelo sétimo e pelos oitavo e nono vídeos: nos seis primeiros optou-se por apresentar a moral do texto da LF, ou seja, em português e, em seguida, realizar uma breve explicação dos acontecimentos da fábula; no sétimo, o ensinamento foi apresentado no final da narrativa do conflito, expondo o que o personagem teria aprendido com a situação vivida; nos dois últimos foi realizada a tradução da moral em Libras ao final da narrativa.

\section{V.1.2 Aspectos enunciativos e discursivos da forma composicional e estilo das fábulas}

No que diz respeito à enunciação da narrativa constitutiva do gênero, foi possível perceber que, em todos os textos, os sujeitos A, C e D assumiram a voz do narrador da história, entretanto de formas diferentes. Nos textos da compilação e naqueles enunciados pelo sujeito D, os autores dos vídeos diferenciaram as vozes do narrador e dos personagens por meio da utilização do discurso indireto e direto respectivamente. Esta maneira de estruturação discursiva torna-se, portanto, muito próxima às características discursivoenunciativas constitutivas dos gêneros contos de fadas descritas por Lodi (2004b). Ou seja, ao assumir a voz do narrador, o enunciador mantém-se posicionado no centro do raio do

\footnotetext{
${ }^{39}$ Nele é possível perceber tratar-se de uma sala de aula, equipada com carteiras, lousa branca, armário e móvel para datashow.
} 
semicírculo do espaço de enunciação e, ao enunciar, seu corpo e seu olhar direcionam-se para frente, de modo a dirigir-se ao seu interlocutor. Esta maior fixidez espacial se em comparação com os personagens, "possibilita garantir certo distanciamento da dinâmica interdiscursiva instaurada entre os personagens, mas, no entanto, não [o] impede de posicionar-se discursivamente apresentando sua avaliação apreciativa da situação” (LODI, 2004b, p. 307). Além disso, a voz do narrador se fez presente por meio do discurso indireto, sendo, no entanto, possível perceber a voz do outro, em uma "interação discursiva constante entre os personagens, as situações e o todo textual” (Idem).

Na compilação, o narrador apareceu no início das fábulas com propósitos bastante específicos: para indicar o tempo, apresentar/caracterizar os personagens e contextualizar a história, como pode ser observado nos exemplos abaixo:

Ex1: Indicação de Tempo: HÁ-MUITO-TEMPO-ATRAS (2, 3, 5 e 6); HISTÓRIA HÁ-MUITOTEMPO-ATRÁS (4); TEMPO-PASSADO (5 e 6).

Ex2: Apresentação dos personagens e suas características: BOI ORGULHOSO PERFEITO IMPONENTE (Cl) MUSCULOSO (Cl) (2); SAPO (realiza o sinal antes de assumir a voz do personagem) (2); C-E-G-O-N-H-A CEGONHA (realiza o sinal antes de assumir a voz do personagem) (3); RATO VELHO (Cl: caracteriza o rato com as orelhas e olhos caídos) EXPERIÊNCIA VIDA (4); (...) AVE P-A-V-Ã-O PAVÃO LINDO, ELEGANTE (Cl: bico, papa e penacho) CAUDA CORES BOLAS VARIADAS VERDE R-O-X-O AZUL BRILHANTE (6).

Ex3: Contextualização da história: LEBRE CONTAR ANIMAIS ELEFANTE ANIMAIS DIFERENTES (1); TARTARUGA (realiza o sinal antes de assumir a voz do personagem) (1); (...) LO-B-O PROCURAR-COMIDA FOME PROCURAR-COMIDA (3); (...) RATOS (Cl: realiza com as mãos as características dos ratos, como as orelhas e bigodes) GRUPO ELES GRUPO MEDO MUITO MEDO PORQUE GATO GRANDE PEGAR ELES $_{\text {PROVOCAR }}$ ELES (4); (...) LEÃO APAIXONAR FILHA LENHADOR FILHA DELE (5).

Para dar voz aos personagens, o sujeito A optou por utilizar o discurso direto, que, de forma diferente do narrador, conforme observou Lodi (2004b), há, na organização discursiva do texto, a presença de um diálogo, compreendido em seu sentido estrito, por meio do qual os interlocutores podem apresentar a palavra e a contrapalavra. Estas vozes se fazem presentes no texto por meio do uso das $1^{\mathrm{a}}$ e $2^{\mathrm{a}}$ pessoas do singular; pelo direcionamento do olhar, que 
pode se voltar ao outro personagem ou para a marcação referencial dos interlocutores; e pelo direcionamento dos sinais em relação aos referentes. Desse modo, as vozes dos diferentes personagens e deles em relação ao narrador não se misturam ou se sobrepõe.

A utilização do discurso direto, nos estudos realizados por Volochínov/Bakhtin (2014) a partir do gênero romance, foi identificada, pelos autores, como uma forma mais rígida de transmissão da palavra de outrem, a qual, por meio do estabelecimento de fronteiras fortes e claras, visa a conservação da autenticidade da palavra do outro. Nos narrativa das fábulas da compilação, tais fronteiras também foram encontradas, entretanto, essa escolha enunciativa permitiu ao autor uma maior liberdade para se expressar a partir da materialidade da Libras, sendo capaz de garantir uma melhor exploração das dinâmicas entre os diálogos e ações dos personagens a partir das escolhas enunciativas permitidas pela língua. Essa dinamização se tornou possível pela utilização do jogo de olhares para a marcação de referentes e pelo uso de classificadores para a realização das ações.

Importante destacar ainda que a maneira pela qual a marcação de referência dos personagens foi realizada constituiu-se como um importante elemento para a diferenciação das vozes presentes no texto. Segundo discutiu Ferreira Brito (1995), é possível diferentes formas de se referenciar pessoas e objetos em língua de sinais: ela pode ser realizada por meio do uso de pronomes pessoais, demonstrativos e possessivos, mas "também através do uso do termo comparativo, da mudança de posição do corpo, do uso de classificadores e, até mesmo, do uso de olhadelas” (p.116).

Nos vídeos presentes na compilação, foi possível observar que a troca de olhares e a alteração das posições do corpo do sujeito A foram as formas mais utilizadas por ele. Este processo pode ser observado, por exemplo, na narrativa da fábula “A Lebre e a Tartaruga”:

\section{Ex4: Fábula (1) - A Lebre e a tartaruga}

(...)

Narrador: TARTARUGA.

Tartaruga: (o sujeito A curva seu corpo para frente, posiciona-se à esquerda do espaço de enunciação, ergue as mãos, com a configuração das patas de uma tartaruga, até a altura do peito). OI (direciona o olhar para cima) ${ }_{\mathrm{EU}} \mathrm{DESAFIAR} \mathrm{V}_{\mathrm{VOCE}}$ (direcionando o sinal para cima em direção à lebre).

Lebre: (altera a posição do seu corpo, se posiciona a direita do espaço de enunciação, e direciona o olhar para baixo) vocÊDESAFIAR ${ }_{\mathrm{EU}}$ ?

(...) 
Observa-se assim, que os personagens se fazem presentes no semicírculo enunciativo por meio da mudança de localização do corpo do enunciador, que se posiciona ora a direita, ora a esquerda do centro do espaço de enunciação, e também pelo jogo de olhar entre a tartaruga e a lebre (para cima e para baixo respectivamente). Essas mudanças de posição do sujeito no espaço estabeleceram claras fronteiras entre as vozes de cada personagem, além de lhes garantir uma dinâmica interdiscursiva para a construção da narrativa.

Entretanto, não foi apenas nos diálogos entre os personagens que foi possível perceber as fronteiras entre as vozes das personagens. Na fábula "O Leão Apaixonado”, o lenhador estabeleceu um diálogo consigo próprio, a fim de resolver o conflito causado pela declaração do leão de estar apaixonado por sua filha.

\section{Ex5: Fábula (5) - O leão apaixonado}

Logo ao início da fábula, o leão revela ao lenhador que gostaria de casar com sua filha, pois se encontra apaixonado por ela.

Lenhador para o Leão: (olha para a direita e para baixo, com expressão de estranhamento) VOCÊ LEÃO MINHA FILHA CASAR?

Lenhador para o Lenhador: (posiciona seu corpo à direita do espaço de enunciação, coça a cabeça, olha para a direita e para baixo; em seguida direciona seus olhos para cima, com expressão de preocupação) ELE PERIGOSO PRESAS (Cl), GARRAS (Cl) PEGAR (com movimento para baixo) MINHA FILHA MORRER, NÃO-QUERER (expressão de negação) COMO? (toca os dedos das duas mãos sequencialmente, com expressão pensativa). AH! (realizado por meio de expressão facial e movimento dos lábios). DISFARÇAR. VERDADE NÃO (olhando para frente com o corpo ainda posicionado à esquerda do espaço de enunciação). DISFARÇAR. ACEITAR.

Lenhador para o Leão: ACEITAR (posiciona-se à direita do espaço de enunciação e olhar para baixo, balançando a cabeça positivamente) EU ACEITAR MINHA FILHA CASAR VOCÊ

(...)

Pode-se observar, portanto, nesse exemplo, que o sujeito A foi capaz de apresentar o diálogo interior do lenhador em conflito, por meio da mudança no posicionamento do corpo (direciona o corpo para o lado direito, “dando as costas” ao leão referenciado no mesmo lado) e do direcionamento do olhar (olha para a direita e para baixo em direção ao leão, em seguida, após mudar o posicionamento do corpo, olha para cima e, posteriormente, para frente, onde não havia nenhum referente). Desse modo, os aspectos extraverbais constitutivos do enunciado, corroboraram para que o texto deixasse perceber que o lenhador tinha a si mesmo como interlocutor, demonstrando sua reflexão sobre a maneira que ele usaria para enganar o leão a fim de proteger sua filha e, portanto, de resolver o conflito. 
Outro elemento que auxiliou o enunciador a estabelecer fronteiras entre as vozes e as formas de ser dos personagens, no decorrer das narrativas, disse respeito ao uso de Classificadores (Cl). Segundo Ferreira Brito (1995), o classificador é um morfema que se encontra presente tanto nas línguas orais quanto nas de sinais; entretanto, em função da possibilidade de simultaneidade ${ }^{40}$ na utilização de elementos lexicais, eles se tornam mais frequentes nas línguas de sinais.

No caso da Libras, ainda segundo Ferreira Brito (1995), os Cls constituem-se em morfemas comumente afixados a um item lexical, o que lhe possibilita pertencer à uma classe gramatical determinada, como é o caso de assumirem a função de nome, adjetivos, advérbios de modo ou locativo, mas, como aponta a autora, é mais comum o seu uso nessa língua quando incorporados aos verbos de movimento ou de localização, sendo estes que permitem, ao enunciador, localizar onde ou a quem está sendo realizado o sinal, ou, ainda, o movimento em que as ações vinculadas aos sinais ocorrem. Em sua função de advérbio, a autora explica o uso dos Cls como uma forma de veicular informações/sentidos sobre a maneira como as ações ocorrem no enunciado. Dessa forma, por meio do uso de Cls, o locutor pode, simultaneamente, expressar um sinal, mostrar a relação espacial entre pessoas e coisas, a intensidade de sensações ou sentimentos, entre outros aspectos.

O uso dos Cls é comum ao se narrar uma situação ou uma história, na medida em que ele pode vir a facilitar, ao interlocutor, uma maior percepção das situações e das personagens por intermédio da forma como eles realizam ações e se posicionam. Nos vídeos que compõem a compilação, foi possível perceber o uso de Cls em suas variadas formas:

\section{Função de nome:}

\section{Ex6: Fábula (2) - O Sapo e o Boi}

\section{(...)}

\section{Narrador: SAPO}

Sapo: (posiciona-se a direita do espaço de enunciação, dobrando os joelhos de forma a ficar mais baixo que o boi) ABRIR BOCA $_{\text {FECHAR }}$ BOCA $(\mathrm{Cl})$; ABRIR OLHO $_{\text {FECHAR }}$ OLHO $(\mathrm{Cl}$ ), VER (olha para cima e para a esquerda; expressão de estar surpreso)

$(\ldots)$

2. Função de adjetivo:

\footnotetext{
${ }^{40}$ A possibilidade de, por meio do uso das duas mãos, enunciar duas ações ou duas pessoas ao mesmo tempo.
} 


\section{Ex7: Fábula (2) - O Sapo e o Boi}

(...)

Narrador: BOI (olha para a frente) ORGULHOSO CORPO-PERFEITO IMPONENTE (Cl) MUSCULOSO (Cl)

(...)

3. Função de advérbio de modo:

Ex8: Fábula (2) - A lebre e a tartaruga

(...)

Lebre: (corpo posicionado no local de referência à lebre) CORRE-RAPIDAMENTE (Cl), ORELHAS-PARA-TRAS (Cl) ÁRVORES-FICAM-PARA-TRÁS (Cl)

(...)

4. Simultaneidade de ações:

Ex9: Fábula (3) - O Lobo e a Cegonha

Narrador: L-O-B-O PROCURAR-COMIDA FOME PROCURAR-COMIDA

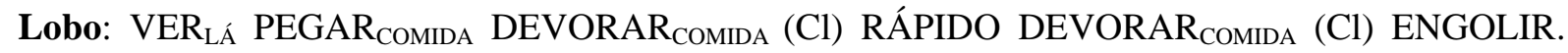

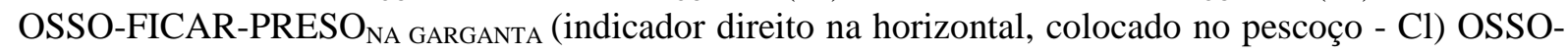
FICAR-PRESO NA GARGANTA $_{(\mathrm{Cl})}$

[ (...)

SOCORRO (com a mão esquerda) ${ }_{\mathrm{ME}}$ AJUDAR (mantendo o indicador)

Complementar a essas funções, destacamos também o uso de classificadores na caracterização dos personagens, como por exemplo, sua forma de andar e de correr:

\section{Ex10: Fábula (5) - O Leão Apaixonado}

(...)

Leão: CORRER ( $\mathrm{Cl}$ - sinal realizado com as mãos em garras) LONGE. CORTAR-GARRAS $S_{\text {DE-TODos- }}$ OS-DEDOS-UM-A-UM (Cl) ARRANCAR-PRESA-ESQUERDA, ARRANCAR-PRESA-DIREITA (expressão de estar banguela) ANDAR SEM-GARRAS $_{\text {( }} \mathrm{Cl}$, com expressão de estar banguela). BATERPORTA (sinal realizado com as mãos fechadas).

\section{(...)}

\section{Ex11: Fábula (7) - A Queixa do Pavão}

\section{(...)}

Pavão: ANDAR (Cl) (sinal realizado com as duas mãos com apenas o polegar, o indicador e o médio) (...) 
O uso do discurso direto e de classificadores permitiu, portanto, que o sujeito A explorasse uma melhor caracterização e diferenciação das vozes dos personagens e destes com a do narrador; entretanto, observou-se que o locutor não elaborou, por meio deles, o que Volochínov/Bakhtin (2014) denominou de elaboração de regras sintáticas, estilísticas e composicionais dos personagens. Ou seja, as escolhas enunciativas do locutor, se analisadas na totalidade dos personagens das seis fábulas por ele enunciadas, mostraram-se bastantes semelhantes, não havendo uma caracterização discursiva específica, mas sim momentos em que demonstram apreciações valorativas/variações de tonalidade e diferenças de intensidade na realização dos sinais. Tais casos foram reconhecidos nos seguintes exemplos:

\section{Ex12: Apreciação valorativa/tonalidade - Fábula (2) - A lebre e a tartaruga \\ (...)}

Tartaruga: CONSEGUIR VENCER (ergue o braço direito, com expressão de alegria)

Animais: CONSEGUIR! ERGUER TARTARUGA

Tartaruga: (o sujeito ergue as mãos para indicar que a tartaruga está sendo erguida pelos animais, além de direcionar seu olhar para baixo) MEDALHA VIVA! (expressão de muita alegria)

Lebre: (olha para frente inconformado) PUXA-VIDA! (continua com a expressão de inconformado e bufa)

(...)

\section{Ex13: Apreciação valorativa/tonalidade - Fábula (6) - A queixa do pavão}

(...)

Pavão: (posiciona-se a direita do espaço de enunciação e dirige o olhar para cima à esquerda) EU HORRÍVEL VOZ (expressão de incomodo), VOZ LINDA ROSTO LINDO, EU-QUERER! INCOMODAR (expressão de incomodo).

Deusa: (posiciona-se a esquerda do espaço de enunciação e dirige o olhar para baixo à direita) OK CALMA VOCÊ (aponta para baixo e para a direita) TER BELEZA, PAVÃO TER.

Pavão: PARAR. BAJULAR PRECISAR-NÃO (balança a cabeça negativamente) PARAR. EUQUERER VOZ LINDA! EU-QUERER!

(...)

Nos exemplos 12 e 13, os personagens se encontravam em conflito e apresentavam apreciações distintas: a vitória da tartaruga é algo muito bom para ela, entretanto causa frustração à lebre; a voz que é um fardo para o pavão não é vista da mesma maneira pela deusa. As apreciações valorativas foram identificadas tanto pelo uso dos sinais, mas, 
principalmente, pelos aspectos extraverbais vinculados a eles, nestes casos em especial, pelas expressões faciais dos personagens.

\section{Ex14: Intensidade na realização dos sinais - Fábula (2) - A lebre e a tartaruga}

\section{(...)}

Lebre: (corpo posicionado no local de referência à lebre) CORRE-RAPIDAMENTE (Cl), ORELHAS-PARA-TRAS (Cl) ÁRVORES-FICAM-PARA-TRÁS (Cl)

Tartaruga: TONTA (realiza o sinal na frente do rosto) LEBRE-SUMIR DA-DE-OMBROS (Cl)

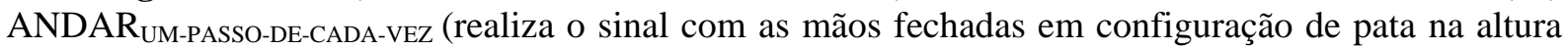
da cintura)

(...)

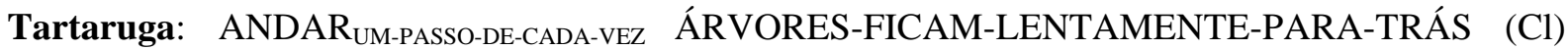
ANDAR $_{\text {UM-PASSO-DE-CADA-VEZ }}$ CAMINHO (realiza o sinal lentamente)

$(\ldots)$

No exemplo 14, a lebre e a tartaruga realizaram a mesma ação, correr/andar pelo caminho na floresta, entretanto, devido a diferença entre os personagens, o sujeito optou pela alteração da intensidade do modo como as ações foram realizadas, o que permitiu demonstrar as características dos animais ao correrem/andarem.

Processo muito próximo ao descrito em relação às escolhas discursivas realizadas pelo sujeito A puderam ser observadas nos vídeos (8) e (9), enunciados pelo sujeito D, no que diz respeito à forma pela qual as vozes dos personagens se fizeram presentes nas fábulas: posicionamento de corpo no espaço de enunciação, direcionamento do olhar e uso de classificadores em suas diferentes formas. No entanto, se em comparação com o sujeito A, essas vozes se sobressaíram no todo do corpo das fábulas, havendo, de forma bastante reduzida, a presença do narrador, que se limitou à apresentar/contextualizar a história: “TODOS-OS-DIAS LEÃO” (8); “TODOS-OS-DIAS TEMPOS-ATRÁS” (9).

De forma diferente foi enunciado a forma composicional da fábula “O Jovem Pastor e o Lobo” pelo sujeito C, que optou por narra-la apenas sob o ponto de vista do narrador, que se tornou responsável pelos mesmos processos descritos na compilação (indicação de tempo, apresentação/caracterização dos personagens, contextualização da história), mas também por enunciar os discursos dos personagens, realizados, portanto, por meio do uso da $3^{\text {a }}$ pessoa do singular ou plural (o jovem pastor, os moradores do vilarejo, o lobo, as ovelhas), e por descrever suas ações e os lugares onde eles se encontravam, como é possível perceber nos exemplos abaixo: 
Ex15: Indicação do Tempo: MAIS-TARDE;

Ex16: Apresentação dos personagens e suas características: ELE PASTOR DESANIMADO

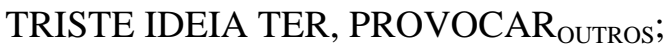

Ex17: Contextualização da história: JOVEM PASTOR TRABALHAR TODO-DIA JUNTAR OVELHAS JUNTAR; GRUPO CASAS; LUGAR-FICAR-OVELHAS;

\section{Ex18: Discurso dos personagens, ações e locais onde se encontravam}

(...)

Narrador: ELE (aponta para a direita) PASTOR CORRER IR GRUPO CASAS (posicionadas à esquerda do espaço de enunciação) GRITAR LÁ (aponta para a direita) LOBO, LOBO, LOBO (mantendo a indicação, com a mão direita, do local onde estaria o lobo). PESSOAS MORAR CASAS ASSUSTAR CORRER (em direção ao local indicado pelo pastor)

(...)

Ex19:

(...)

Narrador: PASTOR CONTINUAR GARGALHAR. LOBO (com olhar de espanto) CHEGAR (inicia o sinal, realizado com o dedo indicador, do lado direito da cabeça, movendo-se para frente; acompanha movimento do dedo com a cabeça) LOBO DE-VERDADE. ELE (aponta para a direita) LOBO PEGAR MUITAS-OVELHAS. ELE (aponta para a direita) PASTOR DESESPERADO E-

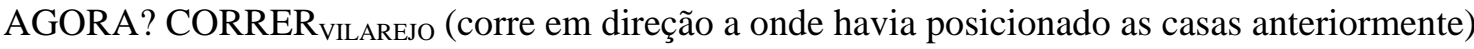

(...)

Ao estudar as formas de discurso no romance, Volochínov/Bakhtin (2014) levantaram a problemática da palavra de outrem, mas especificamente da palavra citada que se faz presente por meio discurso direto, do discurso indireto e do discurso indireto livre nas obras romanescas; a constituição dessas formas foi compreendida pelos autores como reflexos das relações sociais estáveis entre falantes de uma língua. Como discutido anteriormente nesse capítulo, o discurso direto foi descrito por Volochínov/Bakhtin (2014) como uma orientação mais rígida, que permite uma maior conservação do discurso de outrem; o indireto, por sua vez, se utiliza de meios enunciativos mais sutis e versáteis que permitem ao locutor infiltrar suas réplicas e suas apreciações valorativas no discurso citado. Nessa segunda orientação, Volochínov/Bakhtin (2014) ainda observaram que na relação entre palavras do autor e 
palavras de outrem, o contexto narrativo se esforça para desfazer a estrutura compacta e fechada próprias do discurso citado com o objetivo de absorver e apagar suas fronteiras.

Esse apagamento de fronteiras só é possível, pois, como descreveram Volochínov/Bakhtin (2014), a transmissão da palavra de outrem por meio do discurso indireto (no caso desse trabalho das vozes dos personagens por meio da voz do narrador) ocorreu simultaneamente com uma análise, o que resultou no que o autor denominou de "transmissão analítica do discurso de outrem” (p. 165. Ênfase dos autores). Em suas análises, os autores identificaram que essa orientação do discurso exige que o locutor elabore formas enunciativas distintas das do discurso direto, visto que os elementos emocionais e afetivos dos personagens não podem ser transpostos literalmente, eles são relativizados e incorporados em uma nova construção no enunciado do narrador. No decorrer deste processo, a voz citada do personagem se mistura com a voz do narrador, resultando em um enunciado bivocal, que possui uma nova tonalidade.

No caso da fábula enunciada pelo sujeito C, foi possível perceber um processo semelhante ao descrito por Volochínov/Bakhtin (2014), na medida em que não foram encontrados no texto enunciados pertencentes especificamente/unicamente aos personagens; suas falas, expressões e avaliações se fizeram presentes por meio dos enunciados do narrador, que, por sua vez, realizou a transmissão das palavras dos personagens juntamente com sua análise/avaliação. Dessa forma, em alguns momentos da narrativa, foi possível perceber uma força maior das vozes dos personagens, enquanto, em outros momentos, estas se encontraram mais “apagadas”, como é o caso, por exemplo, da ênfase dada pelo narrador à gargalhada do menino (ex19), ou mesmo quando ele se desesperou por não saber o que fazer em relação ao lobo (ex19); em outros momentos, essas mesmas apreciações dos personagens foram deixadas em segundo plano, como é o caso dos moradores da vila que se assustaram.

Nesse sentido, a opção discursiva feita pelo sujeito $\mathbf{C}$ exigiu ainda dele uma mudança na forma de dizer dos personagens, sendo necessário, para a transmissão de suas vozes, o uso da terceira pessoa do singular e do plural, assim como indicações espaciais para referenciar os personagens.

A única fábula da compilação cujas escolhas enunciativas se aproximaram do sétimo vídeo foi o texto "Reunião dos Ratos", no qual o sujeito A, ao contextualizar e explicar o motivo da organização de uma reunião pelos ratos, fê-lo por meio da voz do narrador, que apresentou o medo e os conflitos vividos pelos personagens, assim como a necessidade dos ratos se mobilizarem para deterem as ações do gato. Entretanto, posteriormente na história, o 
narrador cedeu lugar para que os três personagens principais - o rato jovem, o rato velho e o coletivo dos ratos - ganhassem voz na história:

\section{Ex20: Fábula (4) - A Reunião dos Ratos}

Narrador: HISTÓRIA ANTIGA RATO (com as duas mãos caracteriza as orelhas e bigodes do animal) GRUPO (posiciona as duas mãos à direita do espaço de enunciação referenciando o grupo de ratos) ELE GRUPO MEDO MUITO-MEDO PORQUE GATO GRANDE PEGAR RATOS PROVOCAR $_{\text {RATOS }}$ PEGAR $_{\text {RATOS }}$ PEGAR $_{\text {RATOS }}$ GRUPO MEDO FUGIR FUGIR MUITO-MEDO.

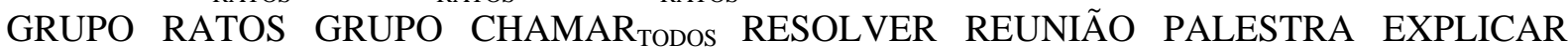
PARAR MEDO.

$(\ldots)$

\section{Ex21: Fábula (4) - A Reunião dos Ratos}

(...)

\section{Narrador: JOVEM}

Rato Jovem: EU (posiciona-se à direita do espaço de enunciação, direciona o olhar para a esquerda e levanta uma das mãos) EU MUITO-INTELIGENTE EU EXPLICAR IDEIA ÓTIMA, PERFEITA

(...)

Coletivo de ratos: MUITO-INTELIGENTE! (ao realizar o sinal o direciona para a esquerda) BOM! VIVA!

(...)

Rato Velho: (posiciona-se no centro do espaço de enunciação, direciona o olhar para frente) PARABÉNS ORGANIZAR BOM

(...)

No caso dessa fábula, foi possível observar que, inicialmente, há uma mescla entre as vozes do narrador e do coletivo de ratos, por meio da qual as fronteiras entre as falas se encontraram quase completamente apagadas; para isso, o sujeito usou a terceira pessoa do plural, referindo-se ao coletivo de ratos e, ao invés de posicionar seu corpo em lugares diferentes, localiza-os no espaço de enunciação e dirige os sinais para o local antes referenciado. Entretanto, posteriormente, ao trazer as vozes dos ratos no discurso direto, as fronteiras são novamente retomadas mediante o uso da primeira e segunda pessoas do singular e do plural, do posicionamento corporal e do direcionamento de olhares.

Dessa forma, nessa seção foi possível perceber nas narrativas, ou como denominou Portella (1983), no “corpo” da fábula, as diferentes possibilidades de se enunciar as vozes e ações dos personagens dentro de seus respectivos contextos narrativos. 


\section{V.1.2.1 Algumas considerações sobre a forma composicional e estilo das fábulas}

A forma composicional da fábula, ou seja, sua narrativa breve em função de um ensinamento, adquiriu, nos vídeos em Libras analisados nessa seção, uma forma bastante semelhante aos textos desse gênero em português. Os textos na língua de sinais se constituíram enquanto narrativas curtas, desenvolvidas por intermédio de personagens animais com características/qualidades/defeitos humanos (ou até mesmo personagens humanos, como é o caso das fábulas 5 e 7) e, em seu ápice, ocorre um conflito que deve esconder ou desencadear um ensinamento.

Foi possível perceber, nas narrativas dos textos enunciados pelos sujeitos A e D, que os autores foram capazes de dar uma maior ênfase aos detalhes, caracterizando os personagens e suas ações em função da materialidade da língua de sinais ser visual, espacial e gestual. Esta particularidade da Libras permitiu ainda que o enunciador realizasse mais de uma ação simultaneamente; ou ainda, que incorporasse nas ações dos personagens formas e movimentos que lhes são próprios.

Nas fábulas escritas com base nas línguas orais, tal aproximação não é possível, visto que o gênero exige que o autor realize uma narração com o menor número de detalhes possíveis, caso contrário o texto acaba se tornando muito extenso e o foco no conflito acaba se dissipando. Este é, inclusive, o motivo pelo qual as fábulas, segundo Portella (1983), utilizam animais como protagonistas da história - para facilitar a contextualização e caracterização dos personagens sem que seja necessário explicar, explicitamente, suas qualidades ou defeitos, pois, na sabedoria popular, os animais já se encontram marcados por características humanas: tartaruga - calma/persistência; raposa - esperteza/inteligência; leão - força/prepotência; etc, conforme discutido no Capítulo III. No caso das fábulas em Libras, o uso de animais também serviu a este propósito, mas devido a materialidade da língua, os locutores tiveram a possibilidade de trazer mais detalhes para a narrativa, sem que o foco no conflito fosse perdido.

Além da ênfase aos detalhes, foi possível perceber, em nossas análises, as diferentes estilos materializados nas escolhas enunciativas dos sujeitos ao narrarem a fábula: o uso do discurso indireto e do direto ou apenas o uso do discurso indireto. No primeiro caso, pudemos encontrar fábulas que utilizaram o discurso indireto apenas para uma breve contextualização ou apresentação da história, como é o caso, principalmente, das fábulas do sujeito D; assim como textos em que o narrador se fez presente também para apresentar e caracterizar os personagens, como realizado pelo sujeito $\mathbf{A}$, em cinco das seis fábulas por ele enunciadas. No 
segundo caso, o sujeito C optou pela construção do “corpo” da fábula trazendo a voz dos personagens apenas por meio do narrador, utilizando-se, para tal, da $3^{\mathrm{a}}$ pessoa do singular e/ou do plural para a realização destes enunciados. Seja qual tenha sido a escolha do locutor, tornou-se possível observar, que nas narrativas que constituíram as fábulas, não houve uma limitação imposta pelo gênero quanto ao tipo de discurso que o enunciador deveria utilizar, da mesma forma como pode ser observado em fábulas escritas em português.

Entretanto, para pensarmos sobre as escolhas enunciativas dos sujeitos, é importante ressaltar que, conforme discutido nos Capítulos II e III deste trabalho, com base na teoria de enunciativa de Bakhtin, tais textos e as escolhas dos sujeitos não foram realizados fora do contexto específico de enunciação; estes enunciados estiveram inseridos na cadeia ininterrupta de comunicação verbal, sendo antecedidos por outros discursos e respondendo a eles, assim como, a eles, também se espera uma resposta.

Além disso, não são discursos alheios às forças linguísticas, pelo contrário, como apontou Bakhtin (1988), “cada enunciação que participa de uma 'língua única’ (das forças centrípetas e das tendências) pertence também, ao mesmo tempo, ao plurilinguismo social e histórico (às forças centrífugas e estratificadoras)” (p. 82); por este motivo, os textos enunciados devem também ser compreendidos como unidades contraditórias e tensas de duas tendências da vida verbal.

Nesse sentido, as escolhas por trazer as vozes dos narradores e dos personagens por meio do discurso indireto ou direto, conforme apontou Volochínov/Bakhtin (2014), podem ser entendidas como reflexos das relações estáveis vividas pelos sujeitos falantes de uma mesma língua. No caso dos surdos, essas relações ocorrem na medida em que eles compartilham esferas sociais diversas nas quais se faz presente a Libras e a língua portuguesa, línguas que ocupam posições linguísticas e hierárquicas distintas e que se relacionam de forma conflituosa e tensa.

Pensar o uso do discurso direto nos vídeos em Libras, remeteu-nos, novamente, aos estudos de Volochínov/Bakhtin (2014), quando os autores afirmam que esse modo de transmissão da palavra de outrem busca conservar sua integridade e autonomia, ou seja, o falante não se sente autorizado a alterá-las. Nos textos em Libras, destacamos que os locutores foram capazes de trazer mais detalhes aos personagens por conta da materialidade da língua, entretanto, não podemos desconsiderar que, em questão de conteúdo e até mesmo do sentido, as vozes dos personagens se aproximaram muito daquelas produzidas na forma composicional 
das fábulas da LF, discursos que abordam uma "temática” que já havia sido avaliada, contestada, discutida historicamente nas e pelas palavras de outrem.

Deve-se considerar ainda que, entre a personalidade do sujeito surdo e o objeto a ser criado (a forma composicional e estilo da fábula em Libras), existe o que Bakhtin (1988) denominou de um "meio flexível, frequentemente difícil de ser penetrado, de discursos de outrem, de discursos 'alheios' sobre o mesmo objeto, sobre o mesmo tema” (p. 86), um jogo complexo no qual o sujeito deve fazer ressoar suas próprias "facetas semânticas e estilísticas" (Idem). Nesse meio de sentidos alheios, encontram-se discursos em Libras e em língua portuguesa, sentidos mais rígidos e mais flexíveis, os quais os sujeitos podem silenciar ou assimilar aos seus discursos. Em questão de semântica, acreditamos que os sentidos das vozes dos personagens se aproximaram muito dos das fábulas na LF, o que implica que, nas narrativas, as apreciações valorativas dos sujeitos A e D pouco ficam aparentes. Em questão de estilística, podemos apenas ressaltar uma maior liberdade dos locutores em seus processos enunciativos, por conta da materialidade da língua.

Entretanto, também não é possível afirmar que essa penetração no discurso de outrem tenha sido efetiva pelo uso restrito do discurso indireto, como foi o caso do sétimo vídeo. Apesar de essa forma de transmissão permitir que o sujeito transmita a palavra alheia junto a réplicas e apreciações, foi possível perceber a elaboração de uma narrativa que se aproximou muito daquela realizada em seu texto fonte, inclusive, com escolhas discursivas bastante próximas, o que tornou o estilo e os sentidos presentes no texto bastante semelhantes em Libras e em português.

Algo similar pode ser observado em relação às morais dos textos, ou, como Portella (1983) denominou, com as “almas” das fábulas.

\section{V.1.3 Aspectos enunciativos, discursivos e semânticos constitutivos do tema das fábulas}

A “alma” da fábula, conforme denominou e discutiu Portella (1983), carrega consigo a essência do gênero, pois é a partir dela e de seu vínculo com o conflito exposto na forma composicional e no estilo do texto, que o interlocutor poderá refletir sobre sua relação com as situações reais da vida.

Para a apresentação das morais, observou-se que, do mesmo modo como realizado com as narrativas das fábulas, os enunciadores fizeram diferentes escolhas enunciativas e de estilo: realizaram uma tradução para Libras considerando os sentidos em língua portuguesa; optaram por uma tradução literal para a Libras da moral em português; ou mantiveram-nas na 
língua fonte, apresentando-as, portanto, em língua portuguesa, para posterior aproximação, em Libras, dos ensinamentos com a vida.

Nesta última escolha ressaltamos a apresentação da moral em língua portuguesa como uma citação da palavra de outrem, em sua forma mais rígida, que ao ser trazida em seu formato “original” não permitiu ao locutor inserir suas próprias palavras. Este processo se deu, no entanto, em momento posterior, quando o locutor tentou explicar a moral retomando partes da narrativa. Nestas explicações, realizadas unicamente pelo sujeito A, foi possível perceber a presença de enunciados carregados de apreciação valorativa, que acabaram por determinar a construção de novos sentidos que, em alguns momentos, não dialogaram diretamente com a narrativa. Este processo fica aparente, principalmente, nos exemplos a seguir:

\section{Ex22: Fábula (2) - O Sapo e o Boi}

Sujeito A: APRENDER O-QUE? PRECISAR MAIS IMPORTANTE AMAR A-MIM-MESMO, IGUAL RESPEITAR NEGROS, SURDOS, JAPONESES, INDÍGENAS TODAS-AS-DIFERENÇAS.

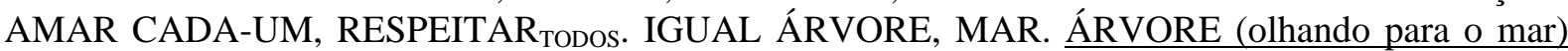
INVEJA, QUERER COPIAR IGUAL=VOCÊ COPIAR ${ }_{\text {IGUAL-VOCÊ }}{ }^{41}$. NÃO (com balanceio de cabeça). ÁRVORE RESPEITAR PRÓPRIO ÁRVORE; MAR RESPEITAR, SOL BONITO PRÓPRIO ELE, L-U-A, LUA BONITA RESPEITAR CADA UEM JEITO-PRÓPRIO, CADA $_{U M}$ PRÓPRIO ACEITAR $_{\text {TODOS, }}$ CADA $_{\text {UM }}$ JEITO PERFEITO. SAPO ACEITAR NÃO JEITO PRÓPRIO, SAPO ACEITAR NÃO, NÃO-GOSTAR. EXPLODIR.

Neste exemplo, o sujeito inicia sua explicação trazendo a importância de se respeitar as diferenças humanas, sejam elas relacionadas às diferentes etnias, línguas ou culturas. Entretanto, ao tentar dar continuidade a sua ideia recorre ao uso do discurso direto para trazer um exemplo que, apesar de possuir personagens distintos, se assemelhou ao conflito vivido pelo sapo e pelo boi narrado no corpo da fábula. Temos, portanto, neste enunciado, o encontro de vozes distintas, que carregam experiências distintas: o conflito vivido pelos personagens e a experiência do próprio locutor. Processo bastante parecido a esse foi observado no exemplo 23:

\section{Ex23: Fábula (6) - A Queixa do Pavão}

APRENDER O-QUE? NÃO-PODER INVEJAR OUTROS NÃO. PESSOAS OUTROS TALENTOS DIFERENTES, ADMIRAR SABERES DIFERENTES. ACEITAR. PAVÃO RECLAMAR, RECLAMAR OPORTUNIDADE É CAUDA BONITA, VOZ FEIA PROBLEMA NÃO-TER. $\underline{\text { PAVÃOOLHAR }}{ }_{\text {PASSARINHO }}$ (dirige o olhar para cima) CANTAR PASSARINHO CANTAR BONITO,

\footnotetext{
${ }^{41} \mathrm{O}$ destaque foi realizado para marcar o uso do discurso direto.
} 
ADMIRAR, NORMAL. TAMBÉM PASSARINHO FEIO, PROBLEMA NÃO, VOZ CANTO PASSARINHOOLHAR ${ }_{\text {PAVÃO }}$ (dirige o olhar para baixo) LINDA CAUDA. TROCAR ENTRE-ELES, RESPEITAR DIFERENÇAS, INVEJAR NÃO (com balanceio de cabeça).

Novamente o autor ressaltou a importância de se respeitar e saber aceitar as diferenças e qualidades de cada um, porém, logo em seguida, retomou as falas dos personagens por meio do discurso direto, inseriu outros para dialogar com o pavão, interrompendo, dessa forma, o seu próprio enunciado, para ceder espaço para a palavra citada. Em outros momentos, no entanto, a relação entre o conflito da fábula e a vida dos surdos foi trazido diretamente pelo autor, sem haver a necessidade do uso do discurso direto. Nestas situações, entretanto, a relação estabelecida na enunciação do sujeito A, pode vir a ser compreendida, possivelmente, apenas por aqueles que compartilhavam o mesmo horizonte social das comunidades surdas naquele período da história, o que não é o caso desta pesquisadora. Este processo pode ser observado no exemplo abaixo.

\section{Ex24: Fábula (4) - A Reunião dos Ratos}

APRENDER O-QUE? PESSOAS FALAR MUITO FAZER-DISCURSO FALAR $_{\text {MUITO, VERDADE }}$ FAZER? DUVIDAR. PRECISAR FALAR, PLANEJAR VERDADE, FAZER CERTO. MUITAS PESSOAS MUITAS FALAR $_{\text {MAL, ERRADO, FAZER ERRADO, FALAR }}$ MAL. VERDADE TROCAR-

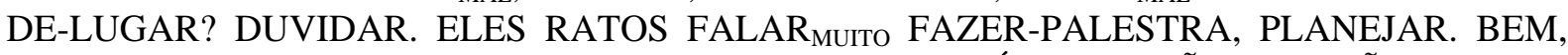
VERDADE COLOCAR-GUIZO-PESCOÇO QUEM? NINGUÉM! EU NÃO, EU NÃO MUITOMEDO. ANTES FALAR FÁCIL.

Torna-se possível observar no exemplo acima que o sujeito A inicia sua explicação trazendo elementos que não aparecem na história, como é o caso das pessoas falarem mal ou indicarem erros uns dos outros ao invés de resolverem a situação e/ou se colocarem no lugar do outro. Entende-se, por todo e qualquer discurso ser dirigido a alguém, tratar-se de alguma situação vivida pelas comunidades surdas naquele momento da história, razão pela qual o enunciador não precisou realizar analogias com outras situações genéricas (como no caso dos exemplos 22 e 23). A voz dos ratos presente no final de seu enunciado ganha também outra tonalidade, pois, ao enunciar, o sujeito A insere no texto sua própria apreciação valorativa, absorvendo o discurso citado (dos ratos) e apagando as fronteiras entre sua voz e a voz dos personagens. Volochínov/Bakhtin (2014) discute que a essência da utilização do discurso direto é atenuar os contornos nítidos da palavra de outrem, fazendo que, como realizou o sujeito A, o interlocutor veja a apreciação do autor e dos personagens como algo único. 
Em outros momentos, foi também possível encontrar explicações que se limitaram a uma retomada da situação vivida pelos personagens das fábulas, sem a apreciação valorativa por parte do sujeito A:

Ex25: - FÁBULA (3) - O Lobo e a Cegonha

APRENDER O-QUE? L-O-B-O CEGONHA INIMIGOS. LOBO CONFIAR CEGONHA $_{\text {A }}$

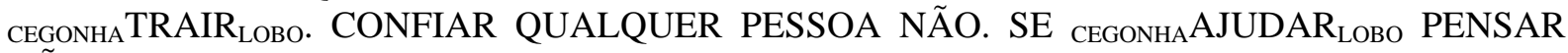
NÃO RECOMPENSA.

Observou-se assim, que a explicação, diferentemente da apresentação da moral em língua portuguesa, se constituiu enquanto uma forma que pode permitir ao sujeito inserir sua apreciação valorativa em forma de réplicas e comentários sobre os sentidos presentes nas fábulas. Novamente, ressaltamos que, ao fazer isso, o locutor deve tentar penetrar no meio flexível dos discursos de outrem, conforme descreveu Bakhtin (1988), fazendo com que suas próprias palavras e concepções ressoem. Entretanto, como pode ser percebido nos exemplos, esta penetração se deu apenas parcialmente, por meio de um posicionamento individual que, logo, cedeu lugar ao conflito presente no corpo das fábulas.

Vale ainda ressaltar que, ao enunciar sua interpretação das morais em língua portuguesa, o sujeito A se encontrava em uma relação dialógica com os muitos outros que poderiam vir a assistir o vídeo (ainda que esses não se encontrassem presentes durante o ato) e com os muitos discursos com concepções ideológicas distintas sobre a língua de sinais e sobre a concepção de "ser surdo". Assim, ao se considerar o contexto no qual as fábulas foram enunciadas, foi possível pensar que suas referências à necessidade do respeito às diferenças humanas constituem-se em (possíveis) respostas ao contexto social da época. Inclusive, a própria elaboração do vídeo pode ser compreendida como uma resposta aos acontecimentos referentes aos movimentos surdos daquele período histórico, considerando-se o desconhecimento da população majoritária em relação à língua de sinais.

No caso do vídeo referente à fábula “O Jovem Pastor e o Lobo”, não temos a presença de moral em língua portuguesa, mas uma tentativa de enuncia-la de modo bastante semelhante ao texto do vídeo indicado como fonte de uso das imagens, no qual a moral foi enunciada ao final (sem ser referenciada como tal) da seguinte maneira: "Foi assim que o menino aprendeu a lição: ninguém acredita num mentiroso mesmo quando ele está dizendo a verdade”, o que é bem próxima da versão encontrada no livro “Fábulas de Esopo” (ASH; HIGTON, 2016, p. 
88): “Os mentirosos podem falar a verdade que ninguém acredita”. Em Libras, o sujeito C optou por enuncia-la da seguinte forma:

\section{Ex27: Fábula (7) - O Jovem Pastor e o Lobo}

Narrador: PASTOR APRENDEU (balança a cabeça afirmativamente). FALAR COISAS

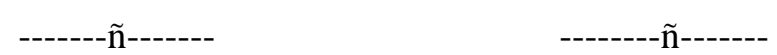

VERDADE PESSOAS. PESSOAS ACREDITAR. PORQUE? ELE (aponta para a direita) MENTIR-MUITO. NÃO-----ñ------

Observou-se, portanto, que, diferentemente dos vídeos da compilação, o sujeito C enunciou a moral a partir da voz do narrador, a mesma responsável pela narrativa do corpo da fábula, fato que não permitiu que o locutor retomasse a posição de autor dos vídeos, tal como realizado pelo sujeito A. Dessa forma, embora a moral da fábula tenha sido enunciada em Libras, a construção usada visou à preservação dos sentidos conforme esperado na LF. Percebeu-se ainda que, ao se comparar as diferentes formas de enunciar as morais encontradas nas análises desta seção, a do sujeito $\mathbf{C}$ foi a que mais se aproximou da de um sujeito que ocupou o papel de tradutor, ou seja, criou um novo texto, respeitou os limites da tradução e buscou, portanto, dizer o “mesmo” a outros a partir de uma nova língua (SOBRAL, 2008).

Por fim, nos textos enunciados pelo sujeito D, observou-se que ele optou por apresentar as morais em seu modo mais "tradicional”: apresentadas ao final da enunciação da narrativa com a indicação “MORAL” ou “MORAL HISTÓRIA”. Entretanto, também foi possível perceber uma tentativa, por parte do locutor, de se manter fiel aos termos utilizados na LF, tal como nos exemplos a seguir:

\section{Ex28: Fábula (8) - O Leão e o Rato}

MORAL HISTÓRIA BOM AJUDAR OUTROS (sinal realizado várias vezes em diferentes locais do espaço de enunciação)

Ao tentar traduzir a moral do texto em LF "Uma boa ação ganha outra”, o sujeito construiu um enunciado que remeteu a uma das temáticas da moral em português, a "boa ação” sendo compreendida no sentido de ser bom ajudar outras pessoas; porém não conseguiu estabelecer um diálogo com a narrativa que antecede a moral, ao não contemplar a ideia de reciprocidade, ou seja, a percepção de que pelo leão ter ajudado o rato, posteriormente, o rato 
ajudou o leão. Ao se analisar o sentido do enunciado em Libras, percebe-se que este não foi alcançado, pois o enunciado “AJUDAR OUTROS”, da forma como produzido, seguiu a lógica da língua portuguesa. A fim de ser possível alcançar este sentido em Libras ele deveria

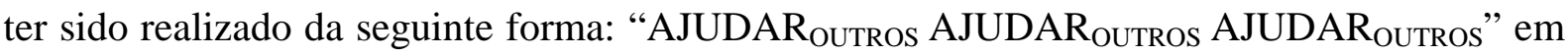
vários locais do espaço.

\section{Ex29: Fábula (9) - O Cão e o Naco de Carne \\ MORAL 1 PÁSSARO MÃO-DENTRO 2 VOANDO}

No caso do vídeo (9), o sujeito D realizou uma tradução termo-a-termo seguindo o enunciado da moral em português: "Mais vale um pássaro na mão do que dois voando”. Desta forma, as escolhas do locutor não foram capazes de estabelecer qualquer sentido em Libras ou em português. Este é um problema do processo tradutório, conforme discutido por Sobral (2008), quando o tradutor considera o texto em LF como “rei e senhor” (p. 58), impondo-se à LA uma lógica que não é dela e, portanto, impossibilitando o estabelecimento de sentidos ao novo texto.

Deste modo, acreditamos que, ao traduzir a palavra em si e não o seu sentido, considerando a completude do texto, ela foi entendida como o elemento mais importante no processo de tradução. Essa postura diferiu, portanto, daquilo que Sobral (2008) denominou de traduzir discursos e não textos, visto que a equivalência entre termos não possibilita uma tradução que considere as condições contextuais da LF e, muito menos, os possíveis sentidos presentes.

Essa forma de enunciação da moral chamou ainda atenção ao considerarmos os contextos e objetivos de produção desse vídeo: um material que, teoricamente, pelo espaço em que foi produzido, visou a aprendizagem da Libras; no entanto, esta língua acabou sendo submetida à língua portuguesa. Materializa-se, neste caso, as tensões entre as línguas, pois, apesar do português não se fazer presente em sua forma escrita, como nos vídeos do sujeito A (o quadro com a moral escrita), o português se impôs por meio das escolhas discursivas em Libras realizadas pelo sujeito $\mathbf{D}$.

\section{V.1.4 Algumas considerações sobre os vídeos de divulgação de língua}

Gostaríamos de finalizar esta seção trazendo, novamente, as semelhanças entre os objetivos dos vídeos. Apesar de terem sido enunciados/produzidos em períodos históricos 
bastante distintos, o intuito dos nove vídeos foi o de divulgar a língua de sinais, seja para surdos, seja para ouvintes. Dessa forma, foram criados textos de fábulas em Libras com funções distintas: a de ensinar a língua por meio de um glossário e de textos em Libras; ou de discutir uma temática - “o dia da mentira” - a partir da tradução de uma fábula sobre os perigos de mentir.

No primeiro caso, destacamos a concepção de língua presente a partir da proposta do seu ensino por meio do glossário e por meio de fábulas. A ideia de que se é possível aprender uma língua por meio de associações entre palavras e sinais nos remete a uma concepção histórica de língua, exposta por Volochínov/Bakhtin (2014), enquanto um sistema fechado de formas linguísticas que se submetem a leis específicas que visam o estabelecimento de ligações entre os elementos no interior do sistema. Nesse processo, desconsidera-se a multiplicidade de linguagens constitutivas da língua, assim como os sentidos nela produzidos em intrínseca relação com a cultura.

É possível perceber que essa concepção influenciou nas escolhas enunciativas dos sujeitos do vídeo ao longo dos textos: eles enunciaram em uma velocidade mais lenta, com pausa entre os eventos da história (que são interrompidas pelo uso das imagens), ou ainda por sua opção de trazer as vozes dos personagens por meio do discurso direto e pela intensificação do uso de classificadores. No caso dos vídeos do sujeito $\mathbf{D}$, temos como resultado traduções termo a termo das morais em português.

Destacamos ainda que o uso de fábulas em Libras para o ensino da língua se aproxima do caso do sétimo vídeo, em que o sujeito $\mathbf{C}$ buscou, por intermédio do texto, ensinar o contexto do surgimento do dia mundial da mentira. Acreditamos que o uso desse texto como pretexto (seja para o ensino de língua ou para a discussão de um conteúdo específico) distancia-o do uso histórico e político da fábula (conforme discutido no Capítulo III), aproximando-se do uso desse gênero nas salas de aulas para o ensino de língua portuguesa para ouvintes: contar histórias e, a partir delas, fazer com que o aluno compreenda apenas as formas composicionais do gênero, ignorando-se assim o tema e a esfera de produção, assim como as possibilidades estilísticas do mesmo.

As escolhas discursivas dos sujeitos permitiram que a forma composicional do gênero fábula fosse enunciada de diferentes maneiras: com narrativas seguidas de morais escritas em português, complementadas por uma explicação; da narrativa em que o narrador explicita o que foi aprendido pelos personagens; e por fim, de uma narrativa seguida de uma exposição da moral. Foi possível perceber também variações quanto aos estilos adotados pelos locutores, 
visto que eles enunciaram a partir do discurso indireto e direto ou apenas pelo uso do discurso indireto. Por fim, a temática do gênero foi mantida, visto que os ensinamentos com base na sabedoria popular foram incorporados aos textos, ainda que de formas distintas, de acordo com os objetivos e contextos dos sujeitos que os enunciaram.

Essas enunciações contribuem para a constituição do gênero fábula em Libras, pois, por se tratar de uma unidade aberta, a cada fábula enunciada há a possibilidade de alterações de suas formas composicionais e de estilo, o que pode, inclusive, leva-lo a se transformar em outro gênero, alterando-se sua esfera e até sua temática. Dessa forma, é possível que a fábula em Libras possa vir a se aproximar cada vez mais da narrativa de histórias infantis ou contos, como é o caso desse gênero em língua portuguesa, que, cada vez mais, caminha para o esquecimento da moral, seja explícita ou implicitamente.

Isso não ocorreu por acaso, conforme discutido no Capítulo III, o uso desse gênero vem se distanciando cada vez mais de suas origens políticas/críticas e se aproximando de fins didático-pedagógicos, normalmente restritos ao ensino da forma composicional da fábula em sala de aula.

Porém, como será possível perceber na seção seguinte, o uso desse gênero em Libras não se restringiu à dimensão apontada pelos vídeos desta primeira seção, ao se vincularem a propósitos políticos. 


\section{V.2. Vídeos com fins políticos}

\section{V.2.1 Apresentação dos vídeos}

Este tópico foi dedicado à análise de 2 (dois) vídeos que, no processo de categorização, foram identificados como desenvolvidos em um contexto político, no qual os surdos estavam mobilizados e lutavam pelo não fechamento das escolas de surdos e pelo reconhecimento e implantação da educação bilíngue nestas escolas. Os dois sujeitos que enunciaram as fábulas, estavam envolvidos ativamente com as mobilizações da época e produziram os vídeos com um intervalo de 15 dias de publicação entre um e outro.

O primeiro vídeo apresentou a fábula intitulada “Os Três Touros e o Leão” (10), foi publicado na plataforma YouTube no dia 11 de abril de 2011, e narrada pelo sujeito A, a mesma pessoa que enunciou as fábulas da compilação há mais de uma década antes da publicação deste vídeo. O segundo trouxe a fábula “A Rã e o Touro”42 (11), porém possui como título na plataforma YouTube "Fabula Rã surdo e Touro surdo vao passeatas para MEC”; foi publicado no dia 26 de abril de 2011 e narrada pelo sujeito E.

Apesar de ambas as fábulas serem identificadas pelas pesquisadoras como de autoria de Esopo, as fontes utilizadas como base para a criação dos vídeos não foram explicitadas nem em seus conteúdos e nem em suas descrições, e, no todo do vídeo, também não foi possível identificar aproximações explícitas a textos escritos, como ocorreu com o uso das legendas nos vídeos da compilação.

Para compreender o tom dos vídeos é preciso, antes, situa-los historicamente; para isso, utilizamos como base o artigo de Campello e Rezende (2014) que, como pessoas surdas que participaram das mobilizações, se propuseram a investigar os acontecimentos desse período. De acordo com as autoras, em 2010 teve início a maior mobilização histórica dos movimentos surdos no Brasil, por conta do não atendimento das propostas dos delegados surdos na Conferência Nacional de Educação (Conae 2010), cujos resultados seriam a base para a elaboração do Plano Nacional de Educação (PNE), ou seja, o alicerce do que seria estipulado para a educação de surdos na próxima década. As propostas não foram atendidas porque, de acordo com as autoras, elas foram entendidas como segregacionistas e, portanto, iam de encontro às políticas nacionais de inclusão. Desconsiderou-se assim, que a política de educação inclusiva contradiz as conquistas obtidas por meio da Lei n ${ }^{\circ} 10.436 / 02$ e do Decreto $\mathrm{n}^{\circ} 5.626 / 05$, sendo compreendida, pelos surdos e pelos pesquisadores que defendem a educação bilíngue, como um retrocesso para a história da educação de surdos.

\footnotetext{
${ }^{42}$ O título é uma variação da fábula "O Sapo e o Boi”.
} 
Em 2011, a diretora de Políticas de Educação Especial da Secretaria de Educação Continuada, Alfabetização, Diversidade e Inclusão (Secadi), Martinha Claret, foi ao Instituto Nacional de Educação de Surdos (Ines) para comunicar, na frente de toda comunidade escolar, que o Colégio de Aplicação, responsável pela educação dos alunos surdos na instituição, seria fechado até o final daquele ano e que, portanto, seus alunos seriam transferidos para as escolas regulares.

Tal situação mobilizou os líderes surdos da época, em especial aqueles que foram educados naquela instituição centenária, e, por meio de vídeos, convocaram toda a comunidade surda para uma passeata histórica que viria a ocorrer em Brasília nos dias 19 e 20 de maio de 2011. Apesar de pouco tempo depois da mobilização dos surdos o Ministério da Educação (MEC) ter negado o fechamento das escolas federais para surdos e cegos, e ter desautorizado o comunicado de Martinha Claret, a luta dos surdos não foi interrompida, deuse continuidade a produção de vídeos por parte dos líderes surdos; a passeata na capital federal permaneceu agendada e houve a produção de um abaixo assinado (em papel e virtualmente) denominado “Em defesa da Educação de Surdos no INES”.

Os vídeos analisados foram produzidos em meio a esse processo de mobilização da comunidade surda, convidavam seus membros para a passeata e discutiam temas associados a este contexto. Dessa forma, o texto (11) foi iniciado pelo sujeito E que propõe um exercício de reflexão a seus interlocutores por meio da narrativa da fábula. Finalizada a fábula, o autor propôs uma discussão dos sentidos nela presentes, buscando pô-la em relação com uma situação apresentada por seus interlocutores surdos. Da mesma maneira, o sujeito A, apesar de não apresentar ou introduzir a fábula, propõe, ao final do vídeo uma discussão semelhante ao do vídeo (11).

Diferentemente dos vídeos analisados na seção anterior, nos vídeos com fins políticos não foi feito o uso de imagens para complementar a narrativa da fábula; além disso, são vídeos sem legendas em português, visto que são dedicados, especificamente, à comunidade surda.

\section{V.2.2 Aspectos enunciativos e discursivos da forma composicional e estilo das fábulas}

Ambos os textos apresentaram as principais características do gênero fábula tal como o concebemos em língua portuguesa: são curtos (o primeiro possui 1 minuto e 50 segundos e o segundo 50 segundos) e mantém a presença de uma ação alegórica - personagens com qualidades humanas que vivem um conflito - que oculta um ensinamento. Essa lição foi 
incorporada de forma semelhante pelos autores dos vídeos e foi analisada no tópico referente ao tema da fábula.

As formas composicionais e estilos das fábulas dos vídeos (10) e (11) apresentaram características bastante semelhantes aos dos vídeos da compilação e do sujeito D. Em suas narrativas, os sujeitos A e $\mathbf{E}$ optaram por apresentar os personagens e marcar a passagem de tempo (neste caso, apenas o vídeo 10) por intermédio da voz do narrador: uso do discurso indireto, corpo no centro do semicírculo de enunciação, com o olhar direcionado para a frente. Maior ênfase, portanto, foi dada à voz dos personagens, realizada por meio do discurso direto, como pode ser observado nos exemplos abaixo:

Ex30: Apresentação dos personagens: 1 LEÃO (10); CHEGAR TOURO SURDO TOURO ANDAR (Cl) (11);

Ex31: Passagem do tempo: DIA-DEPOIS (10); FIM-DIA (10).

Além dessas características, foi possível encontrar, apenas no vídeo (10), no momento de discórdia entre os touros, a presença breve do narrador para explicar a situação; entretanto, ele não mistura sua voz com as dos personagens:

\section{Ex32: Fábula (10) - Os Três Touros e o Leão}

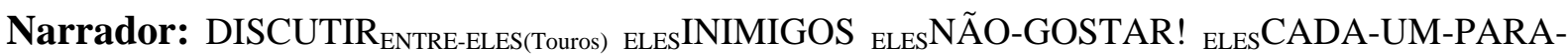
UM-LADO ELESDISCUTIR! 3 ANTES UNIÃO, ELESSEPARAR SOZINHOS.

No que diz respeito às vozes dos personagens, elas foram trazidas por meio do discurso direto, o que permitiu o estabelecimento de diálogos entre os personagens a partir do uso das $1^{\mathrm{a}}$ e $2^{\mathrm{a}}$ pessoas do singular, do direcionamento do olhar para a marcação da referência, pelo posicionamento dos personagens no espaço discursivo e pelo direcionamento dos sinais:

\section{Ex33: Fábula (10) - Os Três Touros e o Leão}

Leão: VONTADE COMER (direciona o olhar e o rosto para a direita, onde estão posicionados os touros) CARNE, PENSAR COMO? ${ }_{\text {LEÃOPEGAR }}$ ELES, CORRER (Cl).

(...)

Ex34: Fábula (10) - Os Três Touros e o Leão 
Touro: DESESPERADO (direciona o olhar para o local onde o leão foi referenciado) AJUDAR $\mathrm{EU}_{\mathrm{EU}}$ (direciona o olhar para o local onde foram posicionados os touros).

$(\ldots)$

\section{Ex35: Fábula (11) - A Rã surda e o Touro surdo}

Touro: TOURO ANDAR (Cl) ANDAR (Cl) MUSCULOSO (Cl) CHEGAR TOUROVER R̃̃ $_{\text {(direciona }}$ o sinal para a esquerda) Touro $V_{E R} R_{R \tilde{A}}-\mathrm{R}_{\mathrm{A}} \mathrm{VER}_{\text {TOURO }}$ (encontro de olhares entre os personagens)

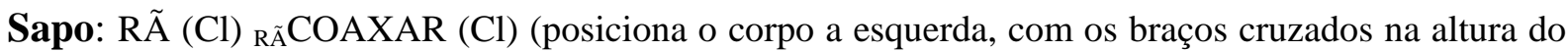

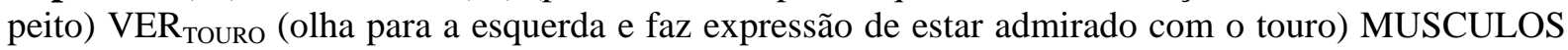
(Cl) ESTICAR-PARA-CIMA (Cl)

$(\ldots)$

Pode-se perceber nos exemplos acima que, de forma semelhante ao observado nos vídeos analisados na seção anterior, os sujeitos A e $\mathbf{E}$ fizeram uso de classificadores com a função de nome (o sapo que é apresentado apenas pelo corpo do sujeito E) e de adjetivo (o corpo musculoso do touro em comparação ao do sapo); o uso do discurso direto permitiu que os autores dos vídeos tivessem maior liberdade para explorar as características físicas dos personagens e descrever suas ações, o que é possibilitado pela materialidade da língua; e não foi possível perceber a estilização das formas de enunciar dos personagens, na medida em que os sujeitos optaram por trazer os discursos em uma velocidade constante. Isto, no entanto, não significa dizer que os personagens não apresentaram apreciações valorativas e entonações distintas.

Apesar das similaridades nas escolhas enunciativas entre os vídeos com fins didáticos e políticos, foi possível perceber que a intenção destes últimos garantiu uma dinâmica distinta em relação aos primeiros: as narrativas destes vídeos fluíram muito mais rapidamente, pois não se encontraram constantemente interrompidas por imagens explicativas; a velocidade ao enunciar foi maior; e não houve pausas para "cortes de cenas”. No entanto, não se pode esquecer que estes vídeos foram produzidos a fim de ser estabelecido um diálogo com seus pares de luta, e não com pessoas que possam estar aprendendo/conhecendo a língua.

\section{V.2.2.1 Algumas considerações sobre a forma composicional e estilos das fábulas}

Com exceção da velocidade de enunciação, não foi possível perceber grandes diferenças nas formas de se enunciar a composição e estilo entre os vídeos e nem nas escolhas enunciativas dos vídeos das seções V.1.1 e V.1.2 (com exceção do sujeito C, conforme já discutido). 
No entanto, um fato chamou atenção na análise do vídeo (10): uma nova faceta foi dada à fábula. Em “Os Três Touros e o Leão”, em língua portuguesa, o leão é o personagem responsável por causar a discórdia e, posteriormente, a desunião entre os touros; na história em Libras narrada pelo sujeito A, esse conflito é gerado por uma competição entre os próprios touros e o leão, oportunista, aproveita o desentendimento dos três para atingir seu objetivo:

\section{Ex36: Fábula (10) - Os Três Touros e o Leão}

Touro 3: BUNDA EMPURRAR $(\mathrm{Cl})_{\text {LEÃOCAIR. }}$

Touro1: EU FORTE.

Touro 2: vocÊPARECER (dirige o olhar para o touro 1) MULHER (em sentido pejorativo)! EU MELHOR EUCHUTAR HOMEM.

Touro 1: NÃO CHIFRE EU MELHOR.

\section{(...)}

Narrador: DISCUTIR ENTRE-ELES(Touros) ELESINIMIGOS ELESNÃO-GOSTAR! ELESCADA-UM-PARAUM-LADO ELESDISCUTIR! 3 ANTES UNIÃO, ELESSEPARAR SOZINHOS.

Leão: SOZINHOS FÁCIL CORRER (Cl) (realiza o sinal em direção aos touros).

Observa-se, portanto, que embora o autor tenha mantido o tema principal da forma composicional da fábula (a necessidade de união dos touros) ele, ao criar o texto, realizou uma adaptação dos motivos que levaram a discórdia dos touros, a fim de que a narrativa pudesse ser posta em diálogo com a situação que os surdos vivenciavam naquele momento histórico, atingindo, assim, os propósitos políticos do vídeo. Pode-se dizer portanto, que a maneira pela qual o sujeito A buscou retratar a relação entre os touros e o leão esteve intrinsicamente relacionada à discussão por ele proposta ao enunciar o tema da fábula.

\section{V.2.3 Aspectos enunciativos, discursivos e semânticos constitutivos do tema das fábulas}

Os sujeitos A e E enunciaram as morais das fábulas de forma distinta, embora ambos tenham realizado uma discussão da temática nela tratada aproximando-a do contexto sóciohistórico que viviam; buscaram os respectivos textos como forma de reflexão e de resposta a alguém, a um grupo de pessoas ou a um acontecimento.

O sujeito A optou por enunciar a moral, discutir seus sentidos para conscientização de seus pares sobre o perigo da desunião entre os surdos para, posteriormente, retomar a moral. O sujeito E, por sua vez, não apresentou a moral, mas realizou uma reflexão dos 
sentidos presentes na narrativa da fábula pondo-os em relação com os incômodos apresentados por seus interlocutores; incômodo este que não foi explicitado no vídeo, mas que é possível depreender pelas discussões realizadas após a narrativa da forma composicional e estilo da fábula.

No texto “Os Três Touros e o Leão”, ao finalizar a narrativa da fábula, o sujeito A realizou um pequeno "corte” no vídeo, para marcar o que seria o fim da narrativa e iniciar a apresentação da moral.

\section{Ex37: Fábula (10) - Os Três Touros e o Leão}

MORAL FALTAR UNIÃO. 3 TOUROS IGUAL VOCÊ FALAR FACULDADE, IGUAL ASSOCIAÇÃO FENEIS UNIR. ASSOCIAÇÃO QUALQUER UNIÃO, SURDOS FECHAR ABANDONAR, PERDER. ELESPEGAR ELESDOMINAR-INCLUSÃO (realiza o sinal na altura do peito e depois "empurra-o" para baixo) GANHAR.

SURDO FORÇA UNIÃO, CONSEGUIR VENCER.

Ao explicar a moral da fábula, o locutor não o fez a partir da voz do narrador e/ou dos personagens, como realizado nos vídeos da compilação, pois não buscou a transmissão da palavra citada, mas sim os sentidos contidos na palavra de outrem presente na moral em português (“A união é a força”). Dessa forma, ele realizou um exercício de assimilação da palavra de outrem com suas "próprias palavras” (BAKHTIN, 1988, p. 142), visto que o sentido da LF não se dissolveu em sua fala, fazendo-se presente a partir da apreciação valorativa do locutor. O sujeito A, portanto, ocupou, neste caso, o lugar de autor do vídeo e não apenas de tradutor.

Assim, iniciou sua explicação dirigindo-se diretamente a outros surdos, expôs que a situação vivida pelos três touros é similar àquela vivida pelos surdos no que diz respeito ao fechamento do Ines e das escolas bilíngues para surdos, e à imposição da política de educação inclusiva. Alerta sobre a necessidade de união das Associações de Surdos e da Federação Nacional de Educação e Integração dos Surdos (Feneis) e, infere-se, sobre o perigo destas instituições realizarem parcerias com outras que não estão de acordo com os direitos linguístico e educacional dos surdos, visto que isso poderia resultar em um enfraquecimento dos movimentos (que se encontravam fortemente mobilizados naquele contexto), resultando no fechamento das escolas e no isolamento ou abandono dos alunos surdos. Nesse contexto, a inclusão, ou melhor, o discurso de educação inclusiva defendido pelo governo federal, poderia se aproveitar da fragilidade dos movimentos surdos (o leão oportunista) e conseguir sair 
vitorioso dessa empreitada. A única maneira, portanto, de resistir e manter as escolas de surdos seria por meio da forte união entre os surdos.

Ao final do vídeo, a moral é novamente enunciada (aparece um “quadro” em que está escrito em português a palavra “moral”), entretanto ela assume, neste vídeo, um tom de convite mais do que propriamente o de uma lição:

\section{Ex38: Fábula (10) - Os Três Touros e o Leão \\ UNIR, VAMOS UNIR (aproxima o sinal da câmera, intensificando-o).}

A partir das reflexões realizadas pelo sujeito A, foi possível perceber que a elaboração deste texto se deu devido a um incômodo ou necessidade de responder a uma situação. Esse sujeito, ao enunciar, não se encontrava isolado ou alheio do mundo ao seu redor, pelo contrário, estava em uma constante relação dialógica com os muitos discursos que circulavam em Libras ou em português, sobre questões políticas que interferiam diretamente nos direitos conquistados pelos surdos: a inclusão social por meio do uso de sua língua.

O vídeo (11), a "Fabula Rã surdo e Touro surdo vao passeatas para MEC”, como o próprio título sugere, também fez referência à organização e à mobilização das passeatas por conta dos movimentos surdos que ocorreram em 2011, porém a partir de uma problemática diferente. Ao invés de apresentar e/ou discutir a moral, como realizado pelo sujeito A, o locutor propôs a reflexão de outra questão que estava em pauta, visto que explicitou a produção do vídeo em resposta a diversos “desabafos” de outros surdos sobre um problema/incômodo referente às participações surdas nas mobilizações que estavam sendo organizadas contra a política do MEC. O sujeito E assim inicia a discussão:

\section{Ex39: Fábula (11) - A Rã surda e o Touro surdo}

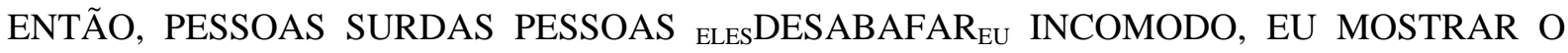
QUE?

ENTÃO, PESSOAS VER INES FECHAR PROBLEMA. ENTÃO, PROBLEMA INES PASSEATA. SURDOS PESSOAS MOSTRAR MOSTRAR, MAS IDEOLOGIA TRABALHAR NADA. INCENTIVAR MOVIMENTAR COISAS NADA, SÓ APARECER (Cl) (realiza o sinal com os dedos indicadores e polegares de ambas as mãos na altura do rosto).

EU (permanece no centro do espaço discursivo) BONITO, APARECER (Cl) EU MESMO EU EU EU RESPONSÁVEL!

FALTAR PESSOAS TRABALHAR (faz o sinal a direita do espaço) LUTAR!

VOCÊ (vira seu corpo para a direita, porém direciona o olhar para a esquerda, onde está posicionada a pessoa que quer aparecer) RESPONSÁVEL NÃO? ENTÃO LUTAR INCENTIVAR. EU 
APARECER (Cl) NÃO? EU AJUDAR BRASILIA NÃO? ENTÃO (o sujeito “dá de ombros”) LUTAR.

ESSE (retorna ao centro no espaço de enunciação e aponta para onde está posicionada a pessoa lutando), ENTÃO, PALHAÇO LUTAR. DESISTIR ALGUNS.

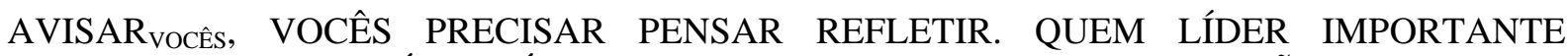
TRABALHAR, PARABÉNS. LÍDER FORA APARECER (CL) RUIM. ENTÃO AVISAR VOCÊS $_{\text {S }}$ CONSCIÊNCIA POUCO.

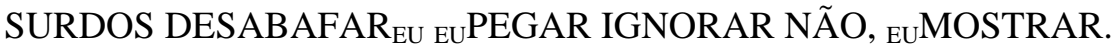

$(\ldots)$

O sujeito E, em sua explicação, trouxe o problema relatado por outros surdos referente a não participação efetiva de alguns líderes/membros nos movimentos surdos, que só tentavam aparecer, ganhar maior visibilidade e “créditos” por ações que foram realizadas por aqueles que, efetivamente, se engajavam nas lutas surdas. Deste modo, esforçavam-se por se destacar na comunidade/mídia, mostrando-se, no entanto, pouco presentes às discussões/lutas dos surdos; tentavam equiparar-se, sem razão, aos líderes que realmente trabalhavam em prol dos interesses/direitos dos surdos. Por este motivo, o sujeito propôs que os outros membros dos movimentos (inclusive os líderes surdos) refletissem sobre os papéis dos líderes na luta pelo não fechamento do Ines, para que uma consciência de luta coletiva viesse a ser desenvolvida.

No entanto, de forma diferente ao realizado pelo sujeito A, não ficou claro em seu texto, a relação que ele estabeleceu entre aqueles que só querem aparecer e os reais lideres com o sapo e o touro, deixando, portanto, em aberto, quais foram os propósitos da fábula para este desabafo.

Vale ressaltar ainda que o sujeito $\mathbf{E}$ fez uso do discurso direto para trazer ao seu texto as vozes (as palavras citadas) dos sujeitos surdos que efetivamente participavam e trabalhavam nas lutas. Essa escolha refletiu, novamente, na dinâmica das inter-relações sociais dos indivíduos na comunicação ideológica verbal (VOLOCHÍNOV/BAKHTIN, 2014, p. 154), revelando a preocupação do locutor do texto de preservar a integridade e autonomia do discurso de seus pares. Porém, em seguida, inseriu o seu comentário, a sua apreciação valorativa, na forma de réplica em relação à situação vivida por esses sujeitos: afirmou que eles podem estar sendo feitos de palhaço, pois lutam exaustivamente para um terceiro assumir os créditos, o que poderia resultar na desistência de muitos nas lutas e movimentos surdos.

Apesar disso, deve-se ressaltar que a forma como os sujeitos aproximaram a vida e a fábula nos vídeos, remeteu-nos, conforme apresentado no Capítulo III deste trabalho, aos 
motivos e às intenções das fábulas de Esopo e Fedro, que, por ocuparem um lugar de desvantagem perante a sociedade em que viviam, buscavam alertar seus iguais contra seus opressores ou inimigos.

\section{V.2.4 Algumas considerações sobre os vídeos com fins políticos}

Foi possível perceber, nos vídeos dessa seção que, os acontecimentos políticos que os surdos viviam naquele momento histórico, os levaram a buscar nas fábulas uma forma de expressar a seus pares os problemas e perigos que envolviam o fechamento das escolas bilíngues para surdos e a importância de uma maior participação e união das comunidades surdas como forma de oposição à tal política. Nesse sentido, observou-se que, por se encontrarem em um diálogo direto com outros usuários da Libras, os sujeitos $\mathbf{A}$ e $\mathbf{E}$ não se preocuparam com a velocidade com a qual enunciavam a língua, fato que se diferenciou se em comparação com os vídeos de fins de divulgação de língua.

Acrescenta-se ainda, que o propósito que levou os locutores a produzirem os vídeos fins políticos e aproximação da temática da fábula com a vida - possibilitou a eles assumirem uma posição de autoria, fato que lhes permitiu uma maior exposição de suas apreciações valorativas e, no caso do sujeito A, a realização de uma alteração nos papéis desempenhados pelo leão (oportunista) e pelos touros (causadores da discórdia).

No entanto, no que diz respeito à forma composicional da fábula, os autores dos vídeos construíram textos distintos: no vídeo (10) o locutor narrou o corpo da fábula, apresentou a moral, realizou uma discussão relacionando seus sentidos com acontecimentos de seu contexto histórico para, por fim, enunciar a moral em um tom não de ensinamento, mas de convite aos surdos a se unirem em prol de uma causa única; no vídeo (11), o locutor optou por narrar a história e, em seguida, finalizar o texto com a reflexão de um problema apresentado por seus interlocutores, sem, no entanto, estabelecer uma clara relação entre os sentidos e personagens da fábula com a situação que ele se propôs a discutir. Ao deixar em aberto às relações a serem feitas, o locutor do vídeo não cumpriu, efetivamente, o seu objetivo, tal qual fez o sujeito A.

No que se refere aos estilos adotados pelos autores, percebeu-se uma aproximação entre a forma deles enunciarem a narrativa das fábulas e os vídeos da compilação e narrados pelo sujeito D: os locutores utilizaram o discurso indireto para a voz do narrador, e o discurso direto para as vozes dos personagens; em relação as morais, os locutores optaram por realizalas na posição de autores do vídeo (e não de narrador, como fez o sujeito C), o que permitiu, 
no caso do sujeito A, a transmissão dos sentidos contidos na fábula em LF a partir de sua apreciação valorativa. Nas morais a transmissão da palavra citada só se fez presente no texto enunciado pelo sujeito $\mathbf{E}$, mediante a utilização do discurso direto.

Em relação à temática do gênero, esta foi mantida no vídeo do sujeito A, que colocou em relação os ensinamentos com base na sabedoria popular com as situações da vida, dando um novo “colorido” à fábula. O mesmo, no entanto, não pode ser dito em relação ao vídeo do sujeito $\mathbf{E}$, que, embora tenha apresentado a forma composicional e estilo da fábula da forma como esperado, não conseguiu estabelecer relação entre o ensinamento nela contida e a discussão realizada.

No que diz respeito às condições concreta de produção dos vídeos gostaríamos de ressaltar que a experiência vivida pelos surdos, em que participantes de um movimento social buscaram, por meio do ciberespaço ${ }^{43}$ (SORJ, 2015, p. 35), mobilizar e informar seus pares de luta sobre os perigos do fechamento das escolas de surdos, nos remete ao trabalho realizado por Sorj (2015), quando ele analisa as transformações na esfera pública nas últimas duas décadas, assim como os movimentos de rua na América Latina nos últimos anos (2010-2013, entre eles o autor destaca: a ocupação de Wall Street, a Primavera Árabe, a mobilização estudantil no Chile, e as manifestações na Espanha, Turquia e Brasil). Esses movimentos tiveram em comum o que o autor denominou de ciberativismo (p. 36), em que alguns integrantes de movimentos sociais utilizaram a esfera virtual para divulgar, mobilizar pessoas para as manifestações que ocorreram e até realizar discussões referentes aos problemas enfrentados. No caso dos surdos, como exemplifica o artigo de Campello e Rezende (2014), ao temer o fechamento das escolas bilíngues, líderes dos movimentos elaboraram vídeos convidando outros surdos a lutarem por seus direitos linguísticos, tais vídeos resultaram em grandes passeatas.

Não é possível, no escopo dessa pesquisa, investigar ou avaliar se os vídeos políticos que utilizaram as fábulas causaram impacto semelhante nas mobilizações da época. Entretanto, os textos analisados nessa seção possuem características explícitas do ciberativismo.

Por fim, gostaríamos de apontar que, apesar de ainda não se constituírem enquanto tal, as fábulas aqui analisadas podem vir a servir como base para a criação do que Portella (1983) denominou “fábulas compostas” (p.137). A fábula composta é, conforme descreveu o autor, a criação de uma nova fábula, a partir de situações de vida específicas e concretas, que tem por

\footnotetext{
${ }^{43}$ Espaços dentro da internet em que sujeitos podem interagir socialmente sem estarem fisicamente presentes.
} 
base uma “fábula simples” (fábulas já existentes). O autor afirmou que isso é possível ao se considerar que, em sua origem, as fábulas esópicas foram criadas a partir de fatos reais e que, posteriormente, os seus seguidores acabaram por inventar outras fábulas com os mesmos ensinamentos.

Assim, apesar da narrativa permanecer praticamente a mesma (carregando os mesmos personagens e acontecimentos das fábulas na LF) foi possível perceber que o sujeito A realizou um deslocamento dos sentidos dos ensinamentos para novas situações, o que pode possibilitar, em enunciações futuras, o surgimento de fábulas compostas em Libras. 


\section{CAPITULO VI}

\section{Considerações Finais}

Esta pesquisa buscou investigar como o gênero fábulas tem se constituído em Libras no principal espaço de compartilhamento de textos entre surdos - a esfera virtual, ao se considerar que a compreensão deste gênero, previsto nos Parâmetros Curriculares Nacionais (PCNs) de Língua Portuguesa, pode também vir a estar presente nas práticas escolares em escolas bilíngues para surdos, espaços nos quais a Libras adquire papel central.

No decorrer da produção dessa dissertação foram realizadas visitas a diferentes escolas bilíngues a fim de se investigar quais gêneros discursos se faziam presentes em contextos de sala de aula. Entretanto, foi possível observar apenas o uso do gênero Contos de Fadas/Histórias Infantis, já discutidos por Lodi (2004b). Por este motivo, o estudo de fábulas pode vir a se constituir em uma possibilidade de trabalho com novos gêneros na sala de aula, respeitando-se, assim, o direto dos alunos surdos ao acesso à uma pluralidade de obras em sua língua.

Essa investigação de cunho qualitativo teve como fundamentação teórica a teoria enunciativa de Bakhtin, o que permitiu que os discursos produzidos em Libras fossem compreendidos dentro de suas condições concretas de enunciação, levando-se em consideração os lugares ocupados pelos indivíduos nos diferentes períodos históricos, assim como suas diferentes escolhas enunciativas. Buscou-se, a partir desse referencial teórico, compreender como o gênero fábula tem sido enunciado pelos reais falantes da Libras na esfera virtual.

Para responder os objetivos de pesquisa, foram selecionados 11 (onze) vídeos para análise, nos quais seus locutores se propuseram a enunciar fábulas reconhecidas como de autoria de Esopo e que já encontram traduzidas em língua portuguesa. Por conta disso, considerou-se que, apesar dos indivíduos não se autoidentificarem como tais, eles acabaram por ocupar a posição de tradutores de textos, visto que propuseram a criação de textos a partir de discursos já existentes.

Por esta particularidade, foi preciso compreender os textos dos sujeitos surdos não como um gênero inédito à essa língua, mas, como apontou Sobral (2008), mas como uma derivação de gêneros já existentes na língua fonte dos textos utilizados para tradução. De 
acordo com o autor, é impossível pensar em uma transposição de sentidos entre línguas que não resulte em alterações e variações enunciativas, ou seja, é impossível pensar em uma transposição de gênero que não sofra mudanças no processo.

Dessa forma, apesar das fábulas em Libras carregarem semelhanças em suas temáticas se comparadas àqueles em língua portuguesa, elas não podem ser compreendidas exatamente como o mesmo gênero, por se encontrarem deslocadas de seu contexto, e se estabelecerem a partir de uma nova língua e cultura. Por este motivo, os textos em Libras também carregaram diferenças significativas, com variações nas escolhas estilísticas e das formas composicionais na enunciação do “corpo” e da “alma” das fábulas.

A investigação foi capaz de identificar, no conjunto dos 11 textos analisados, formas distintas de se enunciar a breve narrativa e as morais que constituem, intrinsicamente, o gênero fábula. Em suas escolhas enunciativas, os indivíduos optaram por fazer uso de formas linguísticas relativamente estáveis para transmitir a palavra de outrem (compreendidas neste trabalho como as vozes dos narradores, personagens e, ainda, de sujeitos não introduzidos na forma composicional e estilo das fábulas), buscando, assim, uni-las em uma relação dinâmica, tensa e complexa aos seus respectivos contextos narrativos.

Essas formas, conforme apontou Volochínov/Bakhtin (2014), refletem as relações dinâmicas da inter-relação social dos indivíduos ativos na comunicação ideológica verbal (no caso dos surdos, nos contextos bilíngues em que se relacionam, falantes de duas línguas distintas, a Libras e o português). Por meio de uma orientação mais “rígida” da transmissão da palavra de outrem, com fronteiras nítidas e uma menor interferência, encontramos o uso do discurso direto tanto nas narrativas, para trazer as vozes das personagens, quantos nas morais para, em alguns casos, reviver os discursos dos personagens (ou ainda, dar exemplo com personagens fictícios), ou, em outros, para trazer as vozes com as quais o autor se encontrava em uma relação dialógica.

O discurso indireto, por sua vez, apesar de ser caracterizado como uma forma mais aberta para a apreciação e inserção de análises e réplicas por parte do enunciador, foi utilizado para transmitir a palavra do narrador e, em alguns casos, até a moral, de uma forma mais enrijecida, mantendo-se fiel à palavra citada e, em alguns momentos, se aproximando à lógica enunciativa da língua portuguesa, como é o caso dos vídeos enunciados pelos sujeitos $\mathbf{C}$ e $\mathbf{D}$.

Entretanto, em especial nas enunciações das morais, foi possível encontrar também momentos em que os sujeitos se tornaram mais “independentes” das palavras de outrem, posicionando-se enquanto autores dos textos, penetrando nos muitos discursos já existentes 
sobre a temática a ser enunciada e fazendo ressoar, a partir de suas próprias palavras - de seu próprio “colorido” - novos sentidos. Por meio deste posicionamento, principalmente o sujeito A, foi capaz de unificar, no interior de suas enunciações, a obra que narrou e suas respectivas experiências de vida.

Não se pode ignorar, ao percebermos as diferenças nas escolhas discursivas dos sujeitos, que cada enunciação se encontrou vinculada aos objetivos/intenções dos projetos discursivos de cada autor para com os vídeos. Organizadas nessa pesquisa enquanto textos com fins de divulgação de língua, encontramos uma forma de enunciar a fábula didatizada, em uma velocidade mais lenta, para que seus interlocutores possam, a partir dos textos, fazer associações entre os sinais em Libras e as palavras em língua portuguesa. Como discutido nos capítulos anteriores, essa proposta de ensino está associada a uma compreensão de língua como um sistema fechado de formas linguísticas que desconsidera a multiplicidade de linguagens constitutivas da língua, assim como os sentidos que nela são produzidos em intrínseca relação com a cultura. Essa didatização do uso do gênero como pretexto para o ensino de língua ignora a essência do uso social do gênero e tem-se tornado cada vez mais frequente também nas aulas de língua portuguesa. Não é de se estranhar que a primeira tentativa de criação de fábula encontrada nessa pesquisa, os textos da compilação, aproximese tanto desse modelo.

Entretanto, também foi possível encontrar textos que surgiram de outra necessidade, como foi o caso dos vídeos com fins políticos. Em um contexto de extremo conflito e mobilização dos movimentos surdos, surgiu a necessidade de reflexão, por parte de alguns membros e líderes das comunidades, sobre os problemas e tensões que enfrentavam. Nestes textos tivemos a possibilidade de encontrar discursos produzidos por surdos em diálogo direto com outros surdos, o que garantiu uma nova dinâmica na forma de enunciar, principalmente, a moral da fábula. Nesse sentido, entendemos que as intenções dos vídeos narrados por parte dos sujeitos A e E se aproximaram daquelas de Esopo e Fredo, na origem deste gênero e discutidas por Portella (1983): a partir de histórias fictícias os autores buscavam alertar seus interlocutores sobre problemas reais e ações de inimigos comuns.

Acreditamos que estes textos em muito podem contribuir para a formação dos alunos surdos, visto que permitem percepção das diferentes formas da transmissão da palavra do outro, de como este gênero se constitui em questão de forma composicional e estilo, ou ainda como elaborar uma reflexão a partir de suas próprias palavras e experiências a partir dos sentidos explorados nas narrativas das fábulas, ou seja, permite que a Libras se torne um 
objeto de reflexão e de conhecimento no processo de desenvolvimento de linguagem dos alunos surdos. Estes textos permitem ainda uma discussão sobre as lutas dos movimentos surdos, algo inédito a esses alunos, visto à existência de poucos materiais ou produções que registrem as histórias de lutas desses movimentos. Em contrapartida, a história de lutas ouvintes possui registros nas mais diferentes formas (textos, músicas, filmes, vídeos, etc) que possibilitam que seus alunos conheçam e reflitam sobre as mais variadas produções em língua portuguesa, a partir de obras que, inevitavelmente, carregam percepções de mundo distintas daquelas em Libras. Observou-se ainda que as fábulas em Libras não apresentaram uma única forma possível de enunciação, fato que vai ao encontro do que foi discutido por Bakhtin (2015), gêneros discursivos são enunciados relativamente estáveis, de forma que, a cada nova enunciação, há a possibilidade de perpetuação ou de transformação da unidade genérica. Conforme destacou Sobral (2008), o termo “relativamente estáveis” é a chave para se compreender a dinamicidade dos gêneros, visto que a cada nova enunciação de uma fábula, o gênero se altera, ainda que sejam mantidos seus principais elementos. É exatamente isso que garante que, diferentes formas de enunciar uma fábula, inclusive de diferentes tempos históricos, convivam e constituam este gênero em um determinado período.

Entretanto, a multiplicidade de textos que constituem um mesmo gênero normalmente é ignorada quando absorvida por exercícios pedagógicos. Essa necessidade de centralização de uma forma única de enunciar o gênero nos remete a ideia de força centrípeta, discutida por Bakhtin (1988), pois, diante do plurilinguismo que se faz presente no encontro entre indivíduos de diferentes contextos sociais, a instituição escola busca uma unificação ou, ainda, um reconhecimento apenas das formas linguísticas já reconhecidas historicamente. Isso não significa dizer que as forças centrífugas não estejam presentes na escola, pois o plurilinguismo social penetra os muros da escola nos mais variados discursos dos alunos, de diferentes contextos sociais e épocas.

Mas, ao pensarmos nas concepções e propostas de modelos bilíngues de educação para surdos, conforme concebidos nos documentos de educação “inclusiva” brasileira, não é possível dizer o mesmo em relação à presença de uma variedade de linguagens em Libras dentro do contexto escolar. Isto porque não é garantida, nas classes de ouvintes com a presença de poucos (ou apenas um) surdos e seus respectivos intérpretes, uma multiplicidade de discursos, ou até mesmo de uma troca dialógica entre crianças, jovens e adultos.

É preciso garantir um espaço bilíngue para surdos em que professores, gestores, funcionários e alunos possam compartilhar uma mesma língua; a elaboração de um currículo 
que tenha a Libras como o ponto de partida para todos os processos educacionais e o reconhecimento de que, como a Libras não se constitui a partir do português, processos educacionais pensados nessa língua deva considerar sua materialidade, assim como suas especificidades discursivas e culturais.

Apenas a partir desse reconhecimento é que essa pesquisa poderá contribuir para uma educação bilíngue que tome os gêneros discursivos como base para os processos de reflexão sobre a primeira língua. Não existe enunciação que não passe pelos gêneros discursivos e, por este motivo, esta pesquisa buscou contribuir para a valorização e consideração dos aspectos discursivos da Libras nas diferentes formas de enunciação do gênero fábula; este ainda pode servir de base para discussões que se proponham a pensar na reflexão das escolhas enunciativas da primeira língua, assim como de discussões sobre os muitos sentidos que circulam nas lutas dos movimentos surdos. 


\section{REFERÊNCIAS BIBLIOGRÁFICAS}

AMORIM, M. Cronotopo e exotopia. In: BRAIT, B. (Org.) Bakhtin - Outros conceitos-chave. Editora Contexto: São Paulo, 2012, p. 95-114.

AMORIM, M. O Pesquisador e seu Outro: Bakhtin nas ciências humanas. São Paulo: Musa Editora, 2004.

AMORIM, M. Vozes e silêncio no texto de pesquisa em Ciências Humanas. Cadernos de Pesquisa. Paris, n. 116, p. 7-19, jul./2002.

ASH, R.; HIGTON, B. Fábulas de Esopo. 34ª reimpressão, Companhia das Letrinhas: São Paulo, 2016.

BAKHTIN, M. M. Estética da criação verbal. 6. ed. São Paulo: Martins Fontes, 2011.

BAKHTIN, M. M./VOLOCHÍNOV, V. N. Marxismo e Filosofia da Linguagem, 16a ed. São Paulo: HUCITEC, 2014.

BAKHTIN, M. Questões de Literatura e de Estética - A teoria do romance, $1^{\mathrm{a}}$ ed. São Paulo: Hucitec, 1988.

BRASIL. Lei n. 13.146, de 6 de julho de 2015. Institui a Lei Brasileira de Inclusão da Pessoa com Deficiência (Estatuto da Pessoa com Deficiência). Diário Oficial da União, Brasília, 7 de julho de 2015. Disponível em: http://www.planalto.gov.br/ccivil_03/_Ato2015-2018/2015/Lei/L13146.htm. Acesso: abril de 2016.

BRASIL. Tecnologia Assistiva. 2009b. Disponível em: http://www.pessoacomdeficiencia.gov.br/app/publicacoes/tecnologia-assistiva. Acesso: abril de 2016.

BRASIL. Lei n. 13.005, de 25 de junho de 2014. Aprova o Plano Nacional de Educação - PNE e dá outras providências. Diário Oficial da União, Brasília, 26 jun. 2014. Disponível em: http://www.planalto.gov.br/ccivil 03/ ato2011-2014/2014/lei/l13005.htm. Acesso: abril de 2016.

BRASIL. Decreto $n^{0}$ 6.949, de 25 de agosto de 2009. Promulga a Convenção Internacional sobre os Direitos das Pessoas com Deficiência e seu Protocolo Facultativo, assinados em Nova York, em 30 de março de 2007. 2009a. Disponível em http://www.planalto.gov.br/ccivil_03/_ato20072010/2009/decreto/d6949.htm. Acesso: abril de 2016.

BRASIL. Decreto $n^{\circ}$ 5.626, de 22 de dezembro de 2005. Regulamenta a Lei $n^{\circ} 10.436$, de 24 de abril de 2002, que dispõe sobre a Língua Brasileira de Sinais - Libras, e o art. 18 da Lei no 10.098 , de 19 de dezembro de 2000. Diário Oficial da União, Brasília, 23 de dezembro de 2005. Disponível em http://www.planalto.gov.br/ccivil_03/_Ato2004- 2006/2005/Decreto/D5626.htm. Acesso: abril de 2016.

BRASIL. Política de Educação Especial na Perspectiva da Educação Inclusiva. MEC, 2008. Disponível em http://portal.mec.gov.br/seesp/arquivos/pdf/politica.pdf. Acesso: abril de 2016.

BRASIL. SEF. Parâmetros curriculares nacionais: língua portuguesa. Brasília: MEC/SEF, 1997.

BRASIL. Lei no 10.436, de 24 de abril de 2002. Dispõe sobre a Língua Brasileira de Sinais e dá outras providências. Diário Oficial da União, Brasília, 25 de abril de 2002. Disponível em http://www.planalto.gov.br/ccivil_03/LEIS/2002/L10436.htm. Acesso: abril de 2016.

BRAIT, B. PCNs, gêneros e ensino de língua: faces discursivas da textualidade. In: ROJO, R. (Org.) A prática de linguagem em sala de aula: praticando os PCNs. São Paulo: EDUC; Campinas: Mercado das Letras, 2000, p. 13 - 23.

CAMPELLO, A. R.; REZENDE, P. L. F. Em defesa da escola bilíngue para surdos: a história de lutas do movimento surdo brasileiro. In: Educar em Revista, edição especial n. 2. Editora UFPR: Curitiba, 2014, p. 71-92. 
ELKONIN, D. B. Psicologia do Jogo. WMF Martins Fontes: São Paulo, 2009.

FAÏTA. D. A noção de "gênero discursivo" em Bakhtin: uma mudança de paradigma. In: BRAIT, B. (Org.). Bakhtin, dialogismo e construção do sentido. Editora da Unicamp: Campinas, 1997, p. 141158.

FARACO, C. A. Linguagem e dialogo: as ideias linguísticas do círculo de Bakhtin. Curitiba: Criar Edições, 2003.

FERREIRA-BRITO, L. Por uma gramática de língua de sinais. Tempo Brasileiro: UFRJ: Rio de Janeiro, 1995.

FERNANDES, S.; MOREIRA, L. C. Políticas de educação bilíngue para surdos: o contexto brasileiro. Educar em Revista. Editora UFPR: Curitiba, edição especial n. 2, 2014, p. 51-69.

FIORIN, J. L. O ensino de português nos níveis fundamental e médio: problemas e desafios. In: ERNST, A.; LEFFA, V. J.; SOBRAL, A. (Orgs.) Ensino e Linguagem: novos desafios. EDUCAT: Pelotas, 2014, p. 33-65.

FREITAS, M. T. de A. Implicações de ser no mundo e responder aos desafios que a educação nos apresenta. In: FREITAS, M. T. de A. F. (Org). Educação, Arte e Vida. Autentica Editora: Belo Horizonte, 2013, p. 95-106.

GARCIA, R. M. C. Educação especial na perspectiva inclusiva: determinantes econômicos e políticos. Revista Comunicações, v. 23, n 3, número especial, p. 7 - 26, 2016. Disponível em: https://www.metodista.br/revistas/revistas-unimep/index.php/comunicacoes/article/view/2938/1833

GERALDI, J. W. Bakhtin tudo ou nada diz aos educadores: os educadores podem dizer muito com Bakhtin. In: FREITAS, M. T. de A. F. (Org). Educação, Arte e Vida. Autentica Editora: Belo Horizonte, 2013, p. 11-28

GESSER, A. Do patológico ao cultural na surdez: para além de um e de outro ou para uma reflexão crítica dos paradigmas. Trab. linguist. apl., Campinas, v. 47, n. 1, June 2008. Disponível em: http://www.scielo.br/scielo.php?script=sci arttext\&pid=S0103-18132008000100013\&lang=pt

Acesso: Março de 2014

GÓES, M. C. R. de. A abordagem microgenética na matriz histórico-cultural: uma perspectiva para o estudo da constituição da subjetividade. Cadernos CEDES. Piracicaba, ano 20, n. 50, p. 9-25, abril/2010.

GÓES, M. C. R de.; LOPES, P. A linguagem no brincar: repercussões do "faz-de-conta” para o processo de letramento. In: LODI, A. C. B; HARRISON, K. M. P.; CAMPOS, S. R. L. de (Orgs) Leitura e escrita no contexto da diversidade. $2^{\text {a }}$ ed. Editora Mediação: Porto Alegre, 2006, p. 9-18.

GOMÉZ, C. C. La fábula latina: entre ejercicio escolar y pieza literaria. In: Forma Breve: A fábula. Aveiro: Universidade, 2003, p. 33-53.

GOMÉZ, L. F. La fábula esópica: de la tradición gregolatina al siglo XV. In: Atalaya (En línea), n. 14, 2014. Acesso em: julho de 2017. Disponível em: https://atalaya.revues.org/1403

GOULART, C. M. A. Política como ação responsiva: breve ensaio acerca de educação e arte. In: FREITAS, M. T. de A. F. (Org). Educação, Arte e Vida. Autentica Editora: Belo Horizonte, 2013, p. 69-94.

HARRISON, K. M. P.; LODI, A. C. B.; MOURA, M. C. de. Escolas e escolhas: processo educacional dos surdos. In: Otacilio Lopes Filho. (Org.). Tratado de Fonoaudiologia. $2^{\mathrm{a}}$ ed. Ribeirão Preto: Tecmed, 2005, v. , p. 391-421.

KLEIN, M. ; FORMOZO, Daniele. Intersecções de tempos e espaços na educação de surdos. $31^{a}$ Reunião Anual da ANPEd, 2008, Caxambu/MG. Constituição Brasileira, Direitos Humanos e Educação. Rio de Janeiro: ANPED, 2008. v. 1. p. 1-14. Disponível em: http://31reuniao.anped.org.br/1trabalho/GT15-4836--Int.pdf Acesso: fevereiro de 2014. 
KRAMER, S. A educação como resposta responsável: apontamentos sobre o outro como prioridade. In: FREITAS, M. T. de A. F. (Org). Educação, Arte e Vida. Autentica Editora: Belo Horizonte, 2013, p. 29-46.

KYLE, J. O ambiente bilíngue: alguns comentários sobre o desenvolvimento do bilinguismo para surdos. In: Carlos Skliar (Org.). Atualidade da Educação Bilíngue para Surdos. Editora Mediação: Porto Alegre, 1999, p. 15-26.

LAPLANE, A. L. F. de. Notas para uma análise dos discursos sobre inclusão escolar. In: GÓIS, M. C. R. de; LAPLANE, A. L. F. de (Orgs). Políticas e Práticas de Educação Inclusiva. $2^{\mathrm{a}}$ ed. Campinas: Autores Associados, 2007, p. 5-20.

LODI, A.C.B. A leitura como espaço discursivo de construção de sentidos: Oficinas com surdos. 2004. 282f. Tese (Doutorado em Linguística Aplicada e Estudos da Linguagem), Pontifícia Universidade Católica de São Paulo, São Paulo.

LODI, A. C. B. Uma leitura enunciativa da língua brasileira de sinais: o gênero contos de fadas. In: D.E.L.T.A., n. 20:2, 2004b, p. 281-310.

LODI, A.C.B. Educação Bilíngue para Surdos e Inclusão na Política de Educação Especial e no Decreto 5.626/05. Educ. Pesqui., São Paulo, v. 39, n. 1, p. 49-63, jan./mar. 2013.

LODI, A.C.B. Declaraciones de UNESCO, educación de sordos y educación inclusiva: un analisis de la politica nacional de educación de Brasil. Psicología, Conocimiento y Sociedad, v. 4, p. 261-294, 2014a.

LODI, A.C.B. Texto e discurso em Libras: possibilidades de apropriação de práticas de leitura e produção de textos/discursos por alunos surdos. In: ERNST, A.; LEFFA, V.J.; SOBRAL, A. (Orgs). Ensino e Linguagem. Novos Desafios. $1^{\text {a }}$ ed. Pelotas: EDUCAT, 2014b, p.97-126.

LODI, A. C. B.; BORTOLOTTI, E. C. ; CAVALMORETTI, M. J. Z. . Letramentos de surdos: práticas sociais de linguagem entre duas línguas/culturas. Bakhtiniana: Revista de Estudos do Discurso, v. 9, p. 131-149, 2014c.

MACHADO, I. Gêneros discursivos. In: BRAIT, B. (Org.) Bakhtin - Conceitos-chave. Editora Contexto: São Paulor, 2012, p. 151-166.

MACHADO, I. A. Os gêneros e o corpo do acabamento estético. In: BRAIT, B. (Org.). Bakhtin, dialogismo e construção do sentido. Editora da Unicamp: Campinas, 1997, p. 141-158.

MARTUCCELLI, D. Esfera pública, movimentos sociales y juventude. In: SORJ, B.; FAUSTO, S. (Orgs). Internet y movilizaciones sociales: transformaciones del espacio público y de la sociedad civil. Edições Plataforma Democrática: São Paulo, 2015. p. 48 - 95

MENDES, E. G. A radicalização do debate sobre inclusão escolar no Brasil. Revista Brasileira de Educação, v. 11, n. 73, set./dez. 2006, p. 387-405.

MIRANDA, A. S. B. Educação Especial no Brasil: Desenvolvimento Histórico. Cadernos de História da Educação, n. 7, jan./dez. 2008, p. 29-44.

PEREIRA, L. A fábula, um gênero alegórico de proverbial sabedoria. In: Forma Breve: A fábula. Aveiro: Universidade, 2003, p. 21-32.

PELUSO, L.; LODI, A. C. B. La experiencia visual de los sordos. Consideraciones políticas, lingüísticas y epistemológicas. Pró-Posições (UNICAMP. Online), v. 26, p. 59-81, 2015.

PORTELLA, O. O. A Fábula. Revista Letras, v. 32, p. 119- 138, 1983.

RODRÍGUEZ ADRADOS, F. Historia de la fabula grego-latina (I). Editorial de la Universidad Complutense: Madrid, 1979. 
ROJO, R. Modos de transposição dos PCNs às práticas de sala de aula: progressão curricular e projetos. In: ROJO, R. (Org.) A prática de linguagem em sala de aula: praticando os PCNs. São Paulo: EDUC; Campinas: Mercado das Letras, 2000, p. 27 - 38

SKLIAR, C. Apresentação - A localização política da educação bilíngue para surdos. In: Carlos Skliar (Org.). Atualidade da Educação Bilíngue para Surdos. Editora Mediação: Porto Alegre, 1999, p. 7-14.

SOBRAL, A. Dizer o "mesmo" a outros: ensaios sobre tradução. Special Book Services: São Paulo, 2008.

SOBRAL, A. A radicalidade da concepção de linguagem e de gênero discursivo do círculo de Bakhtin: breves comentários. Eutomia, v. 1, n. 04, 2009, p. 1-14.

SORJ, B. On-line/off-line: la nueva onda de la sociedad civil y la transformación de la esfera pública. In: SORJ, B.; FAUSTO, S. (Orgs). Internet y movilizaciones sociales: transformaciones del espacio público y de la sociedad civil. Edições Plataforma Democrática: São Paulo, 2015. p. 11 - 46

SPOSITO, M. P. A sociabilidade juvenil e a rua: novos conflitos e ação coletiva na cidade. Tempo social, São Paulo, v.5, n.1-2, p.161-178, nov. 1994.

STÜRMER, I. E.; THOMA, A. S. Discursos que produzem a educação de bilíngue para surdos na atualidade. Inter-Ação, v. 40, n. 3, set./dez. 2015, p. 573-590.

UNESCO. Declaración Mundial sobre Educación para Todos y el Marco de Acción para Satisfacer las Necesidades Básicas de $\quad$ Aprendizaje. 1990. Disponível em http://www.unesco.org/education/nfsunesco/pdf/JOMTIE_S.PDF. Acesso: abril de 2016

UNESCO (1994). Declaración de Salamanca de principios, política y práctica para las necesidades educativas especiales. Disponível em http://www.unesco.org/education/pdf/SALAMA_S.PDF. Acesso: abril de 2016. 
ANEXOS 


\title{
ANEXO A: Ofício de Aprovação do Comitê de Ética em Pesquisa
}

\author{
Universidade de Sáo Paulo \\ Faculdade de Filosofia, Ciências e Letras de Ribeirão Preto \\ Comitê de Ética em Pesquisa \\ Of.CEtPIFFCLRP-USP/67-dgfs \\ Campus de Ribeirão Preto
}

Ribeirāo Preto, 29 de julho de 2016.

Prezado(a) Pesquisador(a),

Comunicamos a V. Sa. que o projeto de pesquisa intitulado "Gêneros Discursivos em Língua Brasileira de Sinais da esfera educacional" foi analisado pelo Comité de Ética em Pesquisa da FFCLRP. USP, em sua $157^{\text {a }}$ Reunião Ordinária, realizada em 28.07.2016, e enquadrado na categoria: APROVADO (CAAE n. ${ }^{\circ} 56683316.8 .0000 .5407$ ).

Solicitamos que eventuais modificaçōes ou emendas ao projeto de pesquisa sejam apresentadas ao CEP, de forma sucinta, identificando a parte do projeto a ser modificada e suas justificativas, e que, ao término do estudo, um relatório final seja entregue, via Plataforma Brasil.

Atenciosamente,

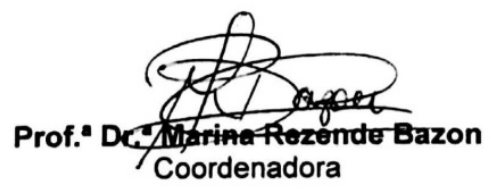

Ao(A) Senhor(a)

Hanna Russo Chacon Rodrigues Silva

Programa de Pós-graduação em Educação da FFCLRP/USP

\author{
CEP - Comitê de Ética em Pesquisa da FFCLRP USP \\ Fone: (16) 3315-4811, 3900 - bloco 23 - casa 37 - 14040-901 - Ribeirâo Preto - SP - Brasil \\ Homepage: htto://mmw.ffclirp. usp, br - e-mail: coetp@ffclro, usp, br
}




\section{ANEXO B: Fábulas Em Português}

\section{Fábulas retiradas do livro “Fábulas de Esopo” (ASH; HIGTON, 2016):}

\section{A Lebre e a Tartaruga}

Um dia uma tartaruga começou a contar vantagem dizendo que corria muito depressa, que a lebre era muito mole, e enquanto falava a tartaruga ria e ria da lebre. Mas a lebre ficou mesmo impressionada foi quando a tartaruga resolveu apostar uma corrida com ela.

“Deve ser só de brincadeira”, pensou a lebre.

A raposa era o juiz e recebia as apostas. A corrida começou, e na mesma hora, claro, a lebre passou à frente da tartaruga. O dia estava quente, por isso lá pelo meio do caminho a lebre teve a ideia de brincar um pouco. Depois de brincar, resolveu tirar uma soneca à sombra fresquinha de uma árvore.

“Se por acaso a tartaruga me passar, é só correr um pouco e fico na frente de novo”, pensou.

A lebre achava que não ia perder aquela corrida de jeito nenhum. Enquanto isso, lá vinha a tartaruga com seu jeitão, arrastando os pés, sempre na mesma velocidade, sem descansar nem uma vez, só pensando na chegada. Ora, a lebre dormiu tanto que esqueceu de prestar atenção na tartaruga. Quando ela acordou, cadê a tartaruga? Bem que a lebre se levantou e saiu zunindo, mas nem adiantava! De longe ela viu a tartaruga esperando por ela na linha de chegada!

Moral: Devagar e sempre se chega na frente.

\section{O Sapo e o Boi}

Há muito, muito tempo existiu um boi imponente. Um dia o boi estava dando seu passeio da tarde quando um pobre sapo todo mal vestido olhou para ele e ficou maravilhado. Cheio de inveja daquele boi que parecia o dono do mundo, o sapo chamou os amigos.

- Olhem só o tamanho do sujeito! Até que ele é elegante, mas grande coisa: se eu quisesse também era.

Dizendo isso o sapo começou a estufar a barriga e em pouco tempo já estava com o dobro do seu tamanho normal.

- Já estou grande que nem ele? - perguntou aos outros sapos.

- Não, ainda está longe! - responderam os amigos. 
O sapo se estufou mais um pouco e repetiu a pergunta.

- Não - disseram de novo os outros sapos -, e é melhor você parar com isso porque vai acabar se machucando.

Mas era tanta a vontade do sapo de imitar o boi que ele continuou se estufando, estufando, estufando - até estourar.

Moral: Seja sempre você mesmo.

\section{O Lobo e a Cegonha}

Um lobo devorou sua caça tão depressa, com tanto apetite, que acabou ficando com um osso entalado na garganta. Cheio de dor, o lobo começou a correr de um lado para outro soltando uivos, e ofereceu uma bela recompensa para quem tirasse o osso de sua garganta. Com pena do lobo e com vontade de ganhar o dinheiro, uma cegonha resolveu enfrentar o perigo. Depois de tirar o osso, quis saber onde estava a recompensa que o lobo tinha prometido.

- Recompensa? - berrou o lobo. - Mas que cegonha pedinchona! Que recompensa, que nada! Você enfiou a cabeça na minha boca e em vez de arrancar sua cabeça com uma dentada deixei que você a tirasse lá de dentro sem um arranhãozinho. Você não acha que tem muita sorte, seu bicho insolente? Dê o fora e se cuide para nunca mais chegar perto de minhas garras! Moral: Não espere gratidão ao mostrar caridade para com um inimigo.

\section{Reunião Geral dos Ratos}

Uma vez os ratos, que vivem com medo de um gato, resolveram fazer uma reunião para encontrar um jeito de acabar com aquele eterno transtorno. Muitos planos foram discutidos e abandonados. No fim um jovem levantou-se e deu uma ideia de pendurar uma sineta no pescoço do gato; assim, sempre que o gato chegasse perto eles ouviriam a sineta e poderiam fugir correndo. Todo mundo bateu palmas: o problema estava resolvido. Vendo aquilo, um rato velho que tinha ficado o tempo todo calado levantou-se de seu canto. O rato falou que era um plano muito inteligente, que com toda a certeza as preocupações deles tinham chegado ao fim. Só faltava uma coisa: quem ia pendurar a sineta no pescoço do gato?

Moral: Inventar é uma coisa, fazer é outra.

\section{O Leão Apaixonado}

Certa vez um leão se apaixonou pela filha de um lenhador e foi pedir a mão dela em casamento. O lenhado não ficou muito animado com a ideia de ver a filha com um marido 
perigoso daqueles e disse ao leão que era muita honra, mas muito obrigado, não queria. O leão se irritou; sentindo o perigo, o homem foi esperto e fingiu que concordava:

- É uma honra, meu senhor. Mas que dentões o senhor tem! Que garras compridas! Qualquer moça ia ficar com medo. Se o senhor quer casar com minha filha, vai ter que arrancar os dentes e cortar as garras.

O leão apaixonado foi correndo fazer o que o outro tinha mandado; depois voltou à casa do pai da moça e repetiu seu pedido de casamento. Mas o lenhador, que já não sentia medo daquele leão manso e desarmado, pegou um pau e tocou o leão para fora de sua casa.

Moral: Quem perde a cabeça por amor sempre acaba mal.

\section{A Queixa do Pavão}

Chateada porque tinha uma voz muito feia, um pavão foi se queixar com a deusa Juno.

- É verdade que você não sabe cantar - disse a deusa. - Mas você é tão lindo, para que se preocupar com isso?

Só que o pavão não queria saber de consolo.

- De que adianta beleza com uma voz destas?

Ouvindo aquilo, Juno se irritou.

- Cada um nasce com uma coisa boa. Você tem beleza, a águia tem força, o rouxinol canta. Você é o único que não está satisfeito. Pare de se queixar. Se recebesse o que está querendo, com certeza ia achar outro motivo para reclamar.

Moral: Em vez de invejar os talentos dos outros, aproveite o seu ao máximo.

\section{O Garoto do “Olha o Lobo"}

Um pastorzinho que cuidava de seu rebanho perto de um povoado gostava de se distrair de vez em quando gritando:

- Olha o lobo! Socorro! Olha o lobo!

Deu certo umas duas ou três vezes. Todos os habitantes do povoado vinham correndo ajudar o pastorzinho e só encontravam risadas diante de tanto esforço. Um dia apareceu um lobo em carne e osso. O menino gritou desesperado, mas os vizinhos acharam que era só brincadeira e nem prestaram atenção. O lobo pôde devorar todas as ovelhas sem ser perturbado.

Moral: Os mentirosos podem falar a verdade que ninguém acredita 


\section{O Leão e o Ratinho}

Um leão, cansado de tanto caçar, dormia espichado debaixo da sombra boa de uma árvore. Vieram uns ratinhos passear em cima dele e acordou. Todos conseguiram fugir, menos um, que o leão prendeu debaixo da pata. Tanto o ratinho pediu e implorou que o leão desistiu de esmagá-lo e deixou que fosse embora. Algum tempo depois o leão ficou preso na rede de uns caçadores. Não conseguindo se soltar, fazia a floresta inteira tremer com seus urros de raiva. Nisso apareceu o ratinho, e com seus dentes afiados roeu as cordas e soltou o leão.

Moral: Uma boa ação ganha outra

\section{Fábula retirada do site https://www.pensador.com/frase/NTgzNzg/}

\section{O Cão e o Naco de Carne}

Um dia, um cão, carregando um naco de carne na boca, ia atravessando uma ponte. Olhando para baixo, viu sua própria imagem refletida na água. Pensando ver outro cão, cobiçou-lhe logo o naco de carne que este tinha na boca, e pôs-se a latir. Mal, porém, abriu a boca, seu próprio o naco de carne caiu na água e perdeu-se para sempre.

Moral da história: Mais vale um pássaro na mão do que dois voando

\section{Fábula retirada do site http://sitededicas.ne10.uol.com.br/fabula-o-leao-e-os-tres- touros.htm}

\section{O Leão e os Três Touros}

Por um longo tempo, três touros sempre pastaram juntos. Um Leão, escondido no mato, espreitava-os na esperança de fazer deles seu jantar, mas tinha receio de atacá-los enquanto estivessem em grupo.

Desse modo, resolveu arquitetar um malicioso plano. Assim, passado algum tempo, por meio de maliciosas e traiçoeiras palavras, e os muitos mexericos que espalhou entre eles, acabou por criar no grupo um desfavorável clima de discórdia, até finalmente conseguir separá-los.

Assim, desfeito o grupo por conta do desentendimento, tão logo eles pastavam sozinhos, atacou-os sem medo algum. E um após outro foram sendo devorados, sempre que ele sentia fome.

Moral da história: União é a força 